The Geological Society of America

Digital Map and Chart 22

2017

\title{
The Geology of the Tecolotlan Graben, Jalisco, Mexico
}

\author{
Bart J. Kowallis \\ Eric H. Christiansen \\ Department of Geological Sciences, Brigham Young University, Provo, Utah 84602, USA \\ Oscar Carranza-Castañeda \\ Centro de Geociencias, Campus Juriquilla, Universidad Nacional Autónoma de México, 76230, Mexico \\ Wade E. Miller \\ Keryn T. Ross \\ David G. Tingey \\ Department of Geological Sciences, Brigham Young University, Provo, Utah 84602, USA
}

\begin{abstract}
The Tecolotlan valley is a small graben $\sim 110 \mathrm{~km}$ southwest of Guadalajara in the northeastern corner of the Jalisco block of west-central Mexico. The graben trends roughly north-south, is $\sim 10 \mathrm{~km}$ wide and $20 \mathrm{~km}$ long, with $\sim 500 \mathrm{~m}$ of topographic relief. It is bounded to the east by a horst of Cretaceous (Albian/Cenomanian) limestone and to the west by a block of Late Cretaceous volcaniclastic sedimentary rocks, lava flows, and ignimbrites (one is $77 \mathrm{Ma}$ ). These volcanic rocks have chemical and mineralogical affinities with continental volcanic arc sequences and record a history of arc volcanism and sedimentation during the Late Cretaceous. The sequence (over $300 \mathrm{~m}$ thick) consists of rhyolitic ash-flow tuffs and trachytic lava flows (lacking pillow structures) interbedded with volcanic debris flow deposits, arkosic fluvial sandstones, and volcanic conglomerates. This suggests that by the Late Cretaceous the continental arc was emergent, but probably still low-standing as it continued to accumulate sediment after the closure of the Arperos oceanic basin and accretion of the Guerrero arc terrane to Mexico.

The Tecolotlan valley contains discontinuously deposited latest Miocene to Recent sediments that are important for their record of extension, magmatism, and diverse vertebrate fauna. Neogene basin fill is divided into older, Late Hemphillian age (ca. 5-4.8 Ma) sedimentary rocks $(\sim 50-60 \mathrm{~m})$ that are mostly fine-grained fluvial and overbank deposits, and younger, Late Blancan-Recent (younger than ca. 2.7 Ma) sediments (up to $30 \mathrm{~m}$ thick) that consist of coarse-grained, high-energy, fluvial deposits. Intercalated with the basin-fill sedimentary rocks are isolated lava flows and pyroclastic-fall beds. It appears that volcanism and extension in the Tecolotlan graben occurred simultaneously with a period of increased volcanic activity along the ESEWNW-trending Tepic-Zacoalco graben. Although extension and volcanism ceased by
\end{abstract}

Kowallis, B.J., Christiansen, E.H., Carranza-Castañeda, O., Miller, W.E., Ross, K.T., and Tingey, D.G., 2017 The Geology of the Tecolotlan Graben, Jalisco, Mexico: Geological Society of America Digital Map and Chart 22, 37 p., doi:10.1130/2017.DMCH022.TXT. For permission to copy, contact editing @ geosociety. org. (9) 2017 The Geological Society of America. All rights reserved. 
Kowallis et al.

ca. 3.6 Ma in the Tecolotlan graben, it continued unabated in the adjacent Colima and Tepic-Zacoalco grabens. Small grabens, like the Tecolotlan graben, found in westcentral Mexico record a widespread episode of Pliocene to early Pleistocene (ca. 51.5 Ma) lacustrine and alluvial sedimentation. These small basins are good examples of how crustal extension may begin with a period of broad, diffuse deformation and faulting followed by a period of concentrated deformation and extension along a few much larger structures. Chemically, the lava flows found within and on the flanks of the graben represent two different magma series-a calc-alkaline, subduction-related suite of basalts, basaltic andesite, and rhyolite, and a more alkaline suite of minette lava and various trachylavas; all show trace element evidence for a subduction-zone component and formed during an episode of slab roll back.

\section{INTRODUCTION}

Intra-arc extension is a distinguishing feature of the TransMexican Volcanic Belt particularly west of $101^{\circ} \mathrm{W}$ longitude where it is underlain by Jurassic to Cenozoic rocks of the accreted Guerrero composite terrane with its thinner (35-40 km thick) crust (Ferrari et al., 2012). The Tecolotlan valley is one of several small ( 10-20 km wide and $\sim 20-40 \mathrm{~km}$ long, see Fig. 1) extensional grabens located in west-central Mexico that are filled with latest Miocene to Recent sedimentary and volcanic rocks (Carranza-Castañeda et al., 1994; Carranza-Castañeda and Miller, 2002; Adams et al., 2006; Mercer et al., 2014). The sedimentary rocks are important for their diverse vertebrate fauna that document the first appearance in North America of several South American immigrants (Carranza-Castañeda and Miller, 1980; Carranza-Castañeda et al., 1981; Miller and CarranzaCastañeda, 1984, 1998b, 1998c, 1999; Carranza-Castañeda et al., 2000; Miller and Carranza-Castañeda, 2001a, 2001b; CarranzaCastañeda and Miller, 2004). These fossils, along with paleomagnetic and radiometric dating of associated sediments, suggest that the land bridge between North and South America formed by or before 4.7-4.8 Ma (Flynn et al., 2005), 1.5-2 million years earlier than previously proposed (Marshall, 1985; Webb, 1997). Based on the ages and distribution of fossils, Campbell et al. (2010) have suggested that the Great American Biotic Interchange (and the associated land bridge) may have begun as early as ca. $9.5 \mathrm{Ma}$ in the Late Miocene.

In order to better understand the distribution of these important latest Miocene to Recent sediments in one of the most productive fossil areas and to provide a framework for tying fossil localities with the local geology, we present here a geologic map and discussion of the geology of the Tecolotlan graben.

\section{GEOLOGIC SETTING}

The Tecolotlan valley is defined by a small north-southtrending graben that is $\sim 10 \mathrm{~km}$ wide and $20 \mathrm{~km}$ long with $\sim 400 \mathrm{~m}$ of topographic relief, located in the northeastern corner of the Jalisco block in west-central Mexico (Fig. 1). The Jalisco block is the westernmost part of the accreted Guerrero composite ter- rane and is composed mainly of a late Cretaceous to Paleocene batholith that intruded Jurassic-Cretaceous sedimentary and volcanic rocks (Campa and Coney, 1983; Schaaf et al., 1995; Valencia et al., 2013; Centeno-García et al., 2003, 2011; Ferrari et al., 2012). These rocks are unconformably overlain by subductionrelated rocks of the Trans-Mexican volcanic belt (Ferrari et al., 2000; Valencia et al., 2013). The Jalisco block is bounded by the Middle America Pacific Trench to the south and west, by the Tepic-Zacoalco rift on the north, and by the Colima rift on the east. The beginning of extension along these two grabens is not well constrained, but they probably started to form in the middle to late Miocene (Allan, 1986; Bandy et al., 2000; Ferrari and Rosas-Elguera, 2000; Gómez-Tuena et al., 2006, 2007; Ferrari et al., 2012). Several smaller grabens in the northern part of the Jalisco block trend NW-SE and are considered part of the TepicZacoalco rift (Ferrari et al., 1994; Bandy et al., 2000; Ferrari and Rosas-Elguera, 2000; Ferrari et al., 2000, 2012). The Tecolotlan graben, however, is farther south and east, located $\sim 50 \mathrm{~km}$ WSW of the triple junction for the Colima, Chapala, and TepicZacoalco rifts. It has a N-S orientation approximately parallel to the northern part of the Colima graben. Other short normal faults nearby have this same northerly orientation (Fig. 1).

The initial activity along the subduction-related TransMexican Volcanic Belt appears to have occurred in the middle Miocene and then developed across Mexico (Gómez-Tuena et al., 2006, 2007; Ferrari et al., 2012). The volcanic rocks dated in the large Tepic-Zacoalco and Colima rifts (Allan, 1986; Moore et al., 1994; Ferrari et al., 2000; Ferrari et al., 2012) suggest several pulses of Neogene tectonic and volcanic activity that may have influenced the geology of the Tecolotlan area (Fig. 2). Along the northern boundary of the Jalisco block, andesitic to rhyolitic ashflow tuffs and lavas of the Sierra Madre Occidental that erupted between 20 and $25 \mathrm{Ma}$ are cut by normal faults and thus predate the formation of the Tepic-Zacoalco rift (Moore et al., 1994; Ferrari et al., 2002, 2007; McDowell and McIntosh, 2012; Bryan et al., 2014). These extensional faults and associated Early Miocene intrusive and volcanic rocks are thought to be associated with the opening of the Gulf of California (Ferrari et al., 2013; Duque-Trujillo et al., 2015). Late Oligocene to Early Miocene volcanism, however, has not been identified in the Jalisco block 
itself (Ferrari et al., 2000). Ferrari et al. (2000, 2012) suggest that in the western portion of the Trans-Mexican Volcanic Belt, the earliest phase of volcanism was dominated by mafic, locally alkaline, eruptions between 11 and $7 \mathrm{Ma}$. This was followed by a lull in volcanic and extensional activity (Ferrari et al., 2012, 2013; Duque-Trujillo et al., 2015). Between ca. 5 Ma and the present, mafic to intermediate composition lavas were accompanied by a second generation of alkaline magmas (Allan, 1986;
Moore et al., 1994; Ferrari et al., 2000; Frey et al., 2007; Ferrari et al., 2012).

The volcanic activity of central and western Mexico is the result of subduction and consumption of the Farallon Plate and its descendants beneath Mexico. The thickness of the crust in this region is $35-40 \mathrm{~km}$ based on gravity and seismic data summarized by Ferrari et al. (2012). Moreover, the lithospheric mantle is very thin or absent beneath much of western Mexico
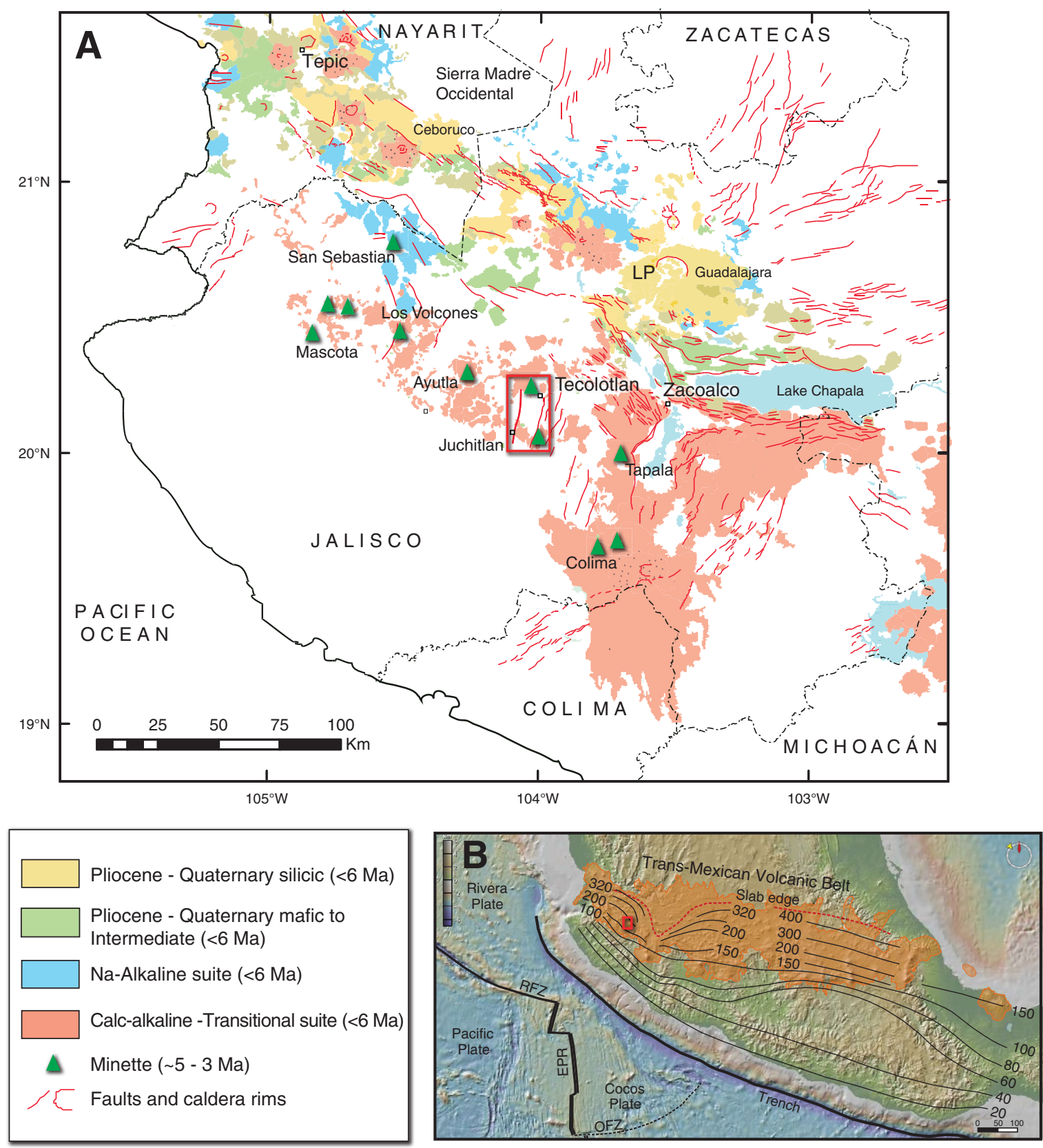

Figure 1. (A) Geologic map of the Jalisco region of Mexico showing the location of the Tecolotlan graben (red box) along with the major volcanic suites. (B)The index map shows relevant plate boundaries in western Mexico and the contours show depth to the subducting slab in kilometers. (Modified from Petrone et al., 2003, Gomez-Tuena et al., 2007; Ferrari et al. 2012). 


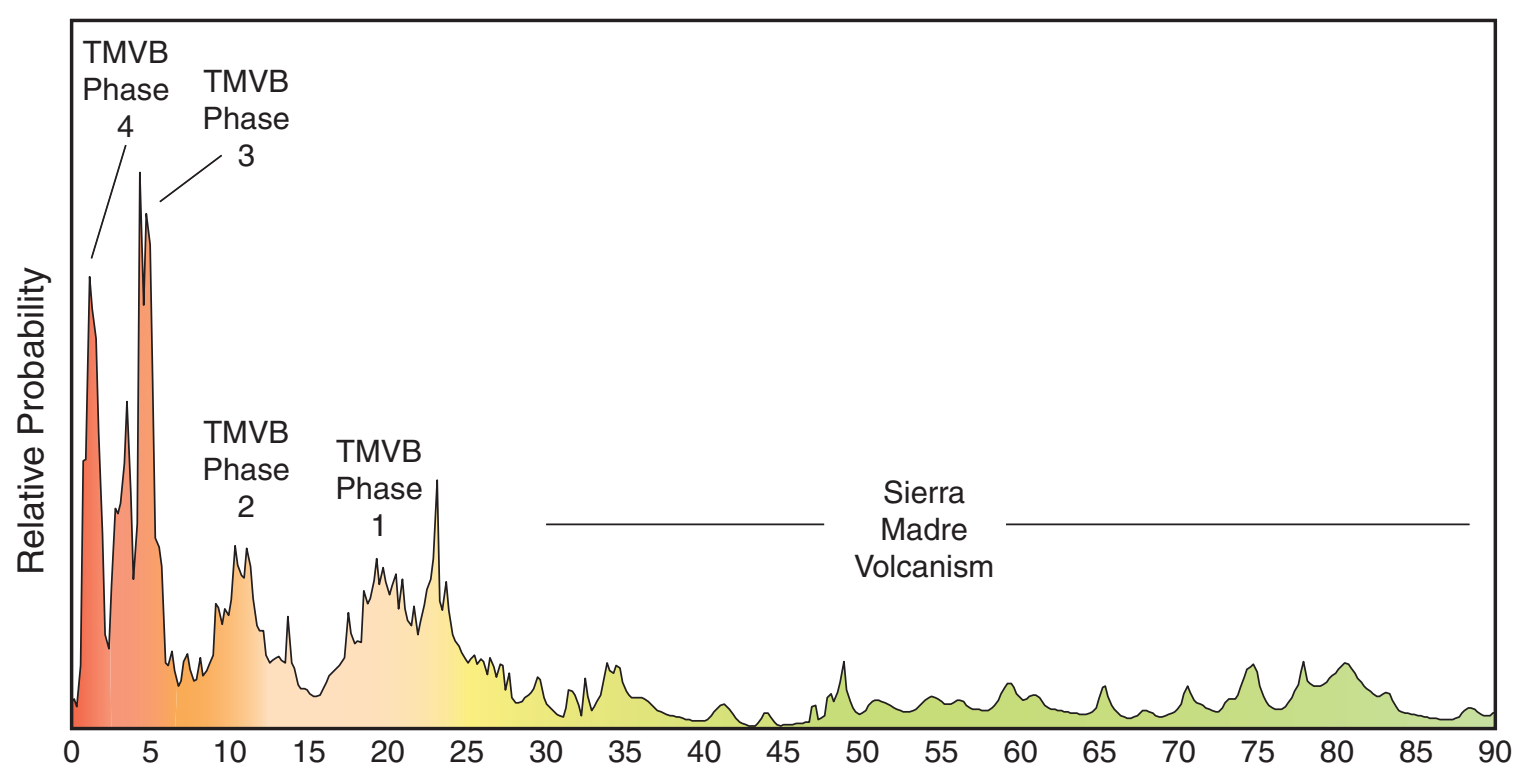

Figure 2. Age probability diagram for dated volcanic rocks in the Tepic-Zacoalco and Colima grabens. Data from Allan (1986), Moore et al. (1994), Nieto-Samaniego et al. (1999), Ferrari et al. (2000, 2013, 2014), Frey et al. (2004, 2007), Centeno-García et al. (2011), Valencia et al. (2013), Duque-Trujillo et al. (2015).

(Manea and Manea, 2011). The oceanic Rivera plate subducts at an angle of $\sim 45^{\circ}$ beneath Mexico and the top of the slab is at a depth of $\sim 120-150 \mathrm{~km}$ beneath Tecolotlan today (Fig. 1; Ferrari et al., 2012).

In the Tecolotlan area, little previous work has been done related to the character and composition of the volcanic and sedimentary rocks that fill the basin and that pre-date the basin, forming its walls and floor. Righter and Rosas-Elguera (2001) studied volcanic rocks nearby in the Ayutla area, and included a few samples from the Tecolotlan graben. Freydier et al. (1997) studied the Cretaceous volcanic/sedimentary sequence a few kilometers east of Tecolotlan in Chiquilistlán. Previous geologic maps at a scale of 1:50,000 that cover the Tecolotlan area were published in 1974 and 2011. The 1974 Tecolotlan quadrangle (F13-D83) published by the Comision de Estudios del Territorio Nacional used a very broad brush for the geology of the area, but was helpful in guiding our field work. The 2011 map of the same quadrangle was published after we had completed our field mapping (Tortoledo et al., 2011). This more recent, improved map has more detail and map units, but does not map Quaternary units in detail, does not subdivide the Tertiary basin fill units, classifies many of the lava flows as Quaternary that give radiometric ages showing they are older, and misidentifies prominent geologic features such as the rhyolite flows forming Cerro Chipahua as intrusive diorite.

Our new work constrains the nature of the pre-rift basement, the age and magnitude of extension, the nature of the sedimentary infill, as well as the volcanic history of the region. These data give us a better understanding of the evolution of Late Cenozoic extension on the Jalisco block and its relationship to the evolving nature of subduction along the plate boundary.

\section{RADIOMETRIC DATING}

To understand the chronologic development of the region, eight samples from the volcanic units in the Tecolotlan region were dated radiometrically (including Jal-Teco-20, Kowallis et al., 1998). Table 1 gives rock units dated, and the ages determined for each of the rocks and mineral separates analyzed.

Five mafic lavas were dated by whole-rock, incremental laser-heating experiments at the Berkeley Geochronology Center (Table 2). Sanidine from the Fish Canyon Tuff (FCT) of Colorado, with a reference age of 28.02 Ma (Renne et al., 1998) was used as a standard. Table 1 also shows a recalculation of the ages using the newer 28.201 Ma standard age for FCT proposed by Kuiper et al. (2008) for comparison. The data in Table 2 and Figure 3 have not, however, been updated with the new FCT age standard. All of the dated samples yielded reasonable spectra and isochrons with ages ranging from 4.9 to $3.6 \mathrm{Ma}$ (Fig. 3). Sanidine and plagioclase (60-100 mesh size) were extracted from two tuffs by standard mineral separation procedures, and age determinations were performed on these grains, also at the Berkeley Geochronology Center, using single-crystal laser-fusion techniques described in detail in Deino and Potts (1990), Deino et al. (1990), Chesner et al. (1991), and Kowallis et al. (1995). The age spectrum for plagioclase grains from JT-K42 (a Cretaceous ash-flow tuff) has one prominent population with an age of $77.0 \pm$ $0.5 \mathrm{Ma}$, but it also contains two spurious young grains and a population of slightly older grains (Fig. 4). One of the younger grains (age 3.1 Ma) is likely a contaminant picked up during the collection of the sample. The other grain, which gives an age of 51.7 Ma, has likely experienced a loss of Ar; its age does not fit 


\begin{tabular}{|c|c|c|c|c|c|}
\hline Sample no. & Description & Method & $\begin{array}{l}\# \\
\text { grains }\end{array}$ & $\begin{array}{l}\text { Mean age } \\
\pm 1 \sigma \\
(\mathrm{Ma})\end{array}$ & $\begin{array}{c}\text { Recalculated age } \\
\pm 1 \sigma \\
(\mathrm{Ma})\end{array}$ \\
\hline JT-K107 & $\begin{array}{l}\text { Sanidine from } \\
\text { andesite ash }\end{array}$ & $\begin{array}{l}\text { Single-crystal, }{ }^{40} \mathrm{Ar} /{ }^{39} \mathrm{Ar} \\
\text { laser step-heating }\end{array}$ & 23 & $2.62 \pm 0.03$ & $2.64 \pm 0.03$ \\
\hline JT-D & Basalt & $\begin{array}{l}\text { Whole rock, }{ }^{40} \mathrm{Ar} /{ }^{39} \mathrm{Ar} \\
\text { laser step-heating }\end{array}$ & & $3.59 \pm 0.01$ & $3.61 \pm 0.01$ \\
\hline JT-K101b & $\begin{array}{c}\text { Basaltic } \\
\text { trachyandesite }\end{array}$ & $\begin{array}{l}\text { Whole rock, }{ }^{40} \mathrm{Ar} /{ }^{39} \mathrm{Ar} \\
\text { laser step-heating }\end{array}$ & & $4.67 \pm 0.01$ & $4.70 \pm 0.01$ \\
\hline JT-K72 & $\begin{array}{c}\text { Basaltic } \\
\text { trachyandesite }\end{array}$ & $\begin{array}{l}\text { Whole rock, }{ }^{40} \mathrm{Ar} /{ }^{39} \mathrm{Ar} \\
\text { laser step-heating }\end{array}$ & & $4.76 \pm 0.02$ & $4.79 \pm 0.02$ \\
\hline JT-K115 & $\begin{array}{c}\text { Basaltic } \\
\text { trachyandesite }\end{array}$ & $\begin{array}{l}\text { Whole rock, }{ }^{40} \mathrm{Ar} /{ }^{39} \mathrm{Ar} \\
\text { laser step-heating }\end{array}$ & & $4.90 \pm 0.02$ & $4.93 \pm 0.02$ \\
\hline JT-K119 & Trachyandesite & $\begin{array}{c}\text { Whole rock, }{ }^{40} \mathrm{Ar} /{ }^{39} \mathrm{Ar} \\
\text { laser step-heating }\end{array}$ & & $4.95 \pm 0.02$ & $4.98 \pm 0.02$ \\
\hline JT-K18 & $\begin{array}{l}\text { Sanidine from } \\
\text { rhyolite ash }\end{array}$ & $\begin{array}{l}\text { Single-crystal, }{ }^{40} \mathrm{Ar} r{ }^{39} \mathrm{Ar} \\
\text { laser step-heating }\end{array}$ & 1 & $4.89 \pm 0.16$ & $4.95 \pm 0.16$ \\
\hline JT-K42 & $\begin{array}{c}\text { Dacite } \\
\text { ash-flow tuff }\end{array}$ & $\begin{array}{c}\text { Single-crystal, }{ }^{40} \mathrm{Ar} /{ }^{39} \mathrm{Ar} \\
\text { laser step-heating }\end{array}$ & 11 & $77.0 \pm 0.5$ & $78.0 \pm 0.5$ \\
\hline
\end{tabular}

Note: Weighted mean ages are calculated using the inverse variance as the weighting factor (Taylor, 1982), while errors in the weighted mean ages are $1 \sigma$ standard error of the mean (Samson and Alexander, 1987). Ages were calculated using an age of 28.02 for the Fish Canyon Tuff standard. Recalculated ages based on new constants determined by Kuiper et al. (2008).

with any known source locally or regionally. The other sample dated by single-grain laser-fusion methods was from a young pyroclastic fall tuff (JT-K107). The age spectrum for sanidine from this sample shows the effects of significant detrital contamination; however, the youngest peak at $2.62 \pm 0.03 \mathrm{Ma}$ is interpreted to be the age of eruption and deposition of the bed (Fig. 4).

Zircon grains (mostly detrital) extracted from one sandstone outcrop (JT-15) were dated by the external detector, fission track method at Brigham Young University. The location of the sandstone outcrop is shown on Plate 1, but it is too small to show on the geologic map. It lies stratigraphically just below a lava flow. Ages were calculated using a zeta factor of $310 \pm 4(2 \sigma)$ determined from several irradiations of SRM-962 glass along with zircon from the Fish Canyon Tuff. The errors for the ages were determined using the method described by Green (1981). The fission track ages are plotted on an age probability diagram (Fig. 5; Hurford et al., 1984; Kowallis et al., 1986) and show peaks at 4.5, 11.4, and 25.0 Ma. These peaks are in agreement with those shown on Figure 3.

\section{GEOCHEMISTRY}

To perform whole-rock chemical analysis, rocks were coarsely crushed and weathered materials and lithic inclusions in the tuffs were removed. The chips were then pulverized using a tungsten carbide shatterbox until the powder was less than $\sim 75 \mu \mathrm{m}$. For major element analysis, rock powder was mixed with lithium metaborate flux and fused to make a glass disk. Trace elements were analyzed in pressed powder pellets with a cellulose backer formed at 20 tons of pressure with a hydraulic press. Both major and trace element analyses were performed on a Siemens SRS 303 X-ray fluorescence (XRF) spectrometer at Brigham Young University. The whole-rock results are summarized in Table 3.

\section{ROCK UNITS}

The rocks mapped in the Tecolotlan graben area range in age from Late Cretaceous to Quaternary and consist of igneous rocks (volcanic and intrusive) and sedimentary rocks (mostly clastic). In this section, we present detailed descriptions of the lithostratigraphic units exposed in the Tecolotlan area. Units are presented in a stratigraphic order based on field relationships that are supported by our new ${ }^{40} \mathrm{Ar}^{-39} \mathrm{Ar}$ ages.

\section{Cretaceous Sedimentary and Igneous Rocks}

\section{Limestone of Los Guajes (Cretaceous-Klg)}

The limestone of Los Guajes is a light to medium gray, crystalline limestone, which contains some poorly preserved fossils. These beds are likely equivalent to the Aptian-Albian age limestones found in the Tepalcatepec Formation as described to the south of the study area (Corona-Esquivel and Alencáster, 1995; Zürcher et al., 2001). Zürcher et. al (2001) describe the Middle Member of the Tepalcatepec Formation as "an approximately 200-m-thick recrystallized massive limestone." Unfortunately, fossils in the formation are extensively recrystallized, making identification difficult. Bivalves and gastropods collected from the formation were not preserved well enough for identification. Samples processed for microfossils were also unproductive. Therefore, the correlation to the Tepalcatepec Formation is tentative. 
Kowallis et al.

TABLE 2. DATA FOR WHOLE ROCK ${ }^{40} \mathrm{Ar} /{ }^{39} \mathrm{Ar}$ STEP-HEATING EXPERIMENTS

\begin{tabular}{|c|c|c|c|c|c|c|c|c|}
\hline Step & $\begin{array}{l}\text { Apparent } \\
\text { age }\end{array}$ & & Error & $\begin{array}{l}\text { Laser } \\
\text { (watt) }\end{array}$ & $\%{ }^{39} \mathrm{Ar}$ & $\begin{array}{c}\text { Cumulative } \\
\%{ }^{39} \mathrm{Ar}\end{array}$ & $\begin{array}{l}\text { \%Radiogenic } \\
{ }^{40} \mathrm{Ar}\end{array}$ & $\mathrm{Ca} / \mathrm{K}$ \\
\hline \multicolumn{9}{|c|}{ JT-D (Lab\# 51086) } \\
\hline$A$ & 14.138 & \pm & 6.781 & 0.5 & 0.0 & 0.0 & 22.9 & 0.00 \\
\hline B & 2.353 & \pm & 0.419 & 1.0 & 0.8 & 0.8 & 6.6 & 2.26 \\
\hline $\mathrm{C}$ & 3.184 & \pm & 0.167 & 1.5 & 2.1 & 2.9 & 19.5 & 2.45 \\
\hline $\mathrm{D}$ & 3.408 & \pm & 0.081 & 2.0 & 3.7 & 6.6 & 33.9 & 3.07 \\
\hline$E$ & 3.725 & \pm & 0.052 & 2.5 & 5.5 & 12.1 & 51.0 & 3.65 \\
\hline $\mathrm{F}$ & 3.630 & \pm & 0.037 & 3.0 & 7.0 & 19.1 & 58.9 & 3.86 \\
\hline G & 3.599 & \pm & 0.055 & 3.5 & 7.7 & 26.8 & 63.6 & 3.71 \\
\hline $\mathrm{H}$ & 3.572 & \pm & 0.024 & 4.0 & 8.1 & 34.9 & 66.7 & 3.35 \\
\hline I & 3.579 & \pm & 0.031 & 4.5 & 7.9 & 42.8 & 67.7 & 3.07 \\
\hline$J$ & 3.591 & \pm & 0.033 & 5.0 & 7.5 & 50.3 & 68.2 & 3.03 \\
\hline K & 3.596 & \pm & 0.025 & 5.5 & 7.0 & 57.3 & 66.8 & 3.01 \\
\hline L & 3.578 & \pm & 0.030 & 6.0 & 6.0 & 63.2 & 64.0 & 3.05 \\
\hline$M$ & 3.595 & \pm & 0.053 & 7.0 & 7.0 & 70.2 & 58.8 & 3.24 \\
\hline $\mathrm{N}$ & 3.655 & \pm & 0.042 & 8.0 & 6.2 & 76.4 & 53.8 & 3.53 \\
\hline 0 & 3.549 & \pm & 0.061 & 9.0 & 4.5 & 80.9 & 49.5 & 3.63 \\
\hline $\mathrm{P}$ & 3.567 & \pm & 0.073 & 10.0 & 3.4 & 84.3 & 46.4 & 3.90 \\
\hline$Q$ & 3.266 & \pm & 0.105 & 11.0 & 2.4 & 86.7 & 40.4 & 4.04 \\
\hline $\mathrm{R}$ & 3.638 & \pm & 0.116 & 12.0 & 1.8 & 88.6 & 42.1 & 4.84 \\
\hline U & 3.274 & \pm & 0.069 & 21.0 & 8.3 & 96.9 & 30.2 & 16.1 \\
\hline V & 3.661 & \pm & 0.135 & 28.0 & 2.0 & 98.9 & 30.5 & 12.1 \\
\hline W & 3.584 & \pm & 0.199 & 35.0 & 1.1 & 100.0 & 29.4 & 11.4 \\
\hline
\end{tabular}

*Plateau: $3.591 \pm 0.013 \mathrm{Ma}$, steps F-P, $72.3 \%$ of the total ${ }^{39} \mathrm{Ar}$ gas released. Irradiation parameter $\mathrm{J}=0.000518 \pm 0.00000031$.

\begin{tabular}{|c|c|c|c|c|c|c|c|c|}
\hline$A$ & 2903 & + & 6661 & 0,5 & م & 0 & 21 & 031 \\
\hline B & 2.897 & \pm & 0.774 & 1.0 & 0.4 & 0.4 & 4.2 & 2.22 \\
\hline C & 3.623 & \pm & 0.265 & 1.5 & 1.0 & 1.4 & 13.0 & 2.67 \\
\hline D & 4.320 & \pm & 0.102 & 2.0 & 2.4 & 3.8 & 32.7 & 3.09 \\
\hline E & 4.985 & \pm & 0.043 & 2.5 & 4.6 & 8.4 & 57.6 & 3.27 \\
\hline $\mathrm{F}$ & 4.845 & \pm & 0.033 & 3.0 & 7.1 & 15.5 & 69.3 & 3.09 \\
\hline G & 4.680 & \pm & 0.025 & 3.5 & 8.9 & 24.5 & 75.0 & 2.69 \\
\hline $\mathrm{H}$ & 4.673 & \pm & 0.021 & 4.0 & 9.7 & 34.1 & 79.3 & 2.29 \\
\hline 1 & 4.691 & \pm & 0.022 & 4.5 & 10.2 & 44.4 & 81.9 & 2.04 \\
\hline $\mathrm{J}$ & 4.698 & \pm & 0.016 & 5.0 & 9.1 & 53.4 & 82.8 & 1.83 \\
\hline K & 4.663 & \pm & 0.022 & 5.5 & 8.3 & 61.7 & 81.4 & 1.78 \\
\hline L & 4.622 & \pm & 0.026 & 6.0 & 6.8 & 68.4 & 77.3 & 1.75 \\
\hline $\mathrm{M}$ & 4.616 & \pm & 0.031 & 7.0 & 7.1 & 75.6 & 71.6 & 1.81 \\
\hline $\mathrm{N}$ & 4.680 & \pm & 0.023 & 8.0 & 6.0 & 81.6 & 67.8 & 1.94 \\
\hline O & 4.699 & \pm & 0.041 & 9.0 & 4.5 & 86.1 & 62.6 & 2.36 \\
\hline $\mathrm{P}$ & 4.602 & \pm & 0.035 & 10.0 & 3.5 & 89.6 & 57.8 & 3.41 \\
\hline Q & 4.610 & \pm & 0.062 & 11.0 & 2.5 & 92.1 & 54.7 & 4.51 \\
\hline$R$ & 4.445 & \pm & 0.086 & 12.0 & 1.9 & 94.0 & 51.2 & 5.04 \\
\hline S & 4.607 & \pm & 0.093 & 14.0 & 1.6 & 95.7 & 52.2 & 5.71 \\
\hline $\mathrm{T}$ & 4.408 & \pm & 0.116 & 17.0 & 1.3 & 97.0 & 47.7 & 5.82 \\
\hline U & 4.842 & \pm & 0.145 & 21.0 & 0.9 & 97.9 & 49.9 & 5.94 \\
\hline V & 4.802 & \pm & 0.099 & 35.0 & 2.1 & 100.0 & 41.6 & 9.03 \\
\hline
\end{tabular}

*Plateau: $4.670 \pm 0.012 \mathrm{Ma}$, steps $\mathrm{G}-\mathrm{Q}, 76.6 \%$ of the total ${ }^{39} \mathrm{Ar}$ gas released. Irradiation parameter $\mathrm{J}=0.0005162 \pm 0.00000031$. 
TABLE 2. DATA FOR WHOLE ROCK ${ }^{40} \mathrm{Ar} /{ }^{39} \mathrm{Ar}$ STEP-HEATING EXPERIMENTS (continued)

\begin{tabular}{|c|c|c|c|c|c|c|c|c|}
\hline Step & $\begin{array}{l}\text { Apparent } \\
\text { age }\end{array}$ & & Error & $\begin{array}{l}\text { Laser } \\
\text { (watt) }\end{array}$ & $\%{ }^{39} \mathrm{Ar}$ & $\begin{array}{c}\text { Cumulative } \\
\%{ }^{39} \mathrm{Ar}\end{array}$ & $\begin{array}{c}\text { \%Radiogenic } \\
{ }^{40} \mathrm{Ar}\end{array}$ & $\mathrm{Ca} / \mathrm{K}$ \\
\hline \multicolumn{9}{|c|}{ JT-K72 (Lab\# 51091) } \\
\hline \multicolumn{9}{|c|}{ A: insufficient gas released } \\
\hline \multirow[t]{2}{*}{ B } & -8.380 & \pm & 2.503 & & & & & \\
\hline & 1.0 & 0.2 & & 0.2 & -6.4 & 4.32 & & \\
\hline C & 2.923 & \pm & 0.521 & 1.5 & 1.0 & 1.2 & 5.2 & 4.17 \\
\hline $\mathrm{D}$ & 5.022 & \pm & 0.155 & 2.0 & 2.3 & 3.5 & 26.7 & 3.79 \\
\hline$E$ & 4.891 & \pm & 0.055 & 2.5 & 5.8 & 9.3 & 55.7 & 3.43 \\
\hline $\mathrm{F}$ & 4.956 & \pm & 0.033 & 3.0 & 7.5 & 16.9 & 79.1 & 3.05 \\
\hline $\mathrm{G}$ & 4.809 & \pm & 0.027 & 3.5 & 10.9 & 27.8 & 84.8 & 2.76 \\
\hline $\mathrm{H}$ & 4.788 & \pm & 0.024 & 4.0 & 10.2 & 38.0 & 88.9 & 2.50 \\
\hline I & 4.755 & \pm & 0.023 & 4.5 & 10.0 & 48.1 & 89.6 & 2.44 \\
\hline $\mathrm{J}$ & 4.762 & \pm & 0.026 & 5.0 & 8.6 & 56.7 & 90.6 & 2.42 \\
\hline K & 4.752 & \pm & 0.025 & 5.5 & 7.8 & 64.5 & 90.4 & 2.46 \\
\hline L & 4.796 & \pm & 0.035 & 6.0 & 6.3 & 70.8 & 90.4 & 2.51 \\
\hline $\mathrm{M}$ & 4.707 & \pm & 0.025 & 7.0 & 6.6 & 77.4 & 86.8 & 2.60 \\
\hline $\mathrm{N}$ & 4.722 & \pm & 0.031 & 8.0 & 5.1 & 82.5 & 86.7 & 2.73 \\
\hline 0 & 4.691 & \pm & 0.054 & 9.0 & 3.6 & 86.1 & 85.2 & 3.20 \\
\hline$P$ & 5.027 & \pm & 0.068 & 10.0 & 2.7 & 88.8 & 89.2 & 5.07 \\
\hline$Q$ & 4.914 & \pm & 0.088 & 11.0 & 2.3 & 91.1 & 85.7 & 8.59 \\
\hline $\mathrm{R}$ & 4.922 & \pm & 0.114 & 12.0 & 1.6 & 92.7 & 80.2 & 8.49 \\
\hline$S$ & 4.615 & \pm & 0.104 & 14.0 & 1.7 & 94.4 & 72.0 & 12.8 \\
\hline$T$ & 4.805 & \pm & 0.144 & 17.0 & 1.2 & 95.6 & 77.2 & 16.4 \\
\hline U & 4.293 & \pm & 0.151 & 21.0 & 1.3 & 96.9 & 68.9 & 18.0 \\
\hline $\mathrm{V}$ & 4.569 & \pm & 0.075 & 35.0 & 3.1 & 100.0 & 72.8 & 18.6 \\
\hline
\end{tabular}

\begin{tabular}{|c|c|c|c|c|c|c|c|c|}
\hline \multicolumn{9}{|c|}{ JT-K115 (Lab\# 51089) } \\
\hline A & 33.829 & \pm & 84.108 & 0.5 & 0.0 & 0.0 & 98.5 & 8.70 \\
\hline B & 2.425 & \pm & 0.654 & 1.0 & 0.3 & 0.3 & 9.3 & 1.85 \\
\hline C & 4.285 & \pm & 0.148 & 1.5 & 1.9 & 2.2 & 32.7 & 1.37 \\
\hline $\mathrm{D}$ & 4.875 & \pm & 0.054 & 2.0 & 5.3 & 7.5 & 58.9 & 1.06 \\
\hline $\mathrm{E}$ & 4.907 & \pm & 0.030 & 2.5 & 9.9 & 17.4 & 75.2 & 0.93 \\
\hline$F$ & 4.931 & \pm & 0.023 & 3.0 & 13.2 & 30.6 & 82.9 & 0.84 \\
\hline G & 4.863 & \pm & 0.017 & 3.5 & 13.6 & 44.2 & 84.6 & 0.83 \\
\hline $\mathrm{H}$ & 4.892 & \pm & 0.022 & 4.0 & 12.2 & 56.4 & 85.9 & 0.83 \\
\hline I & 4.929 & \pm & 0.023 & 4.5 & 10.3 & 66.7 & 85.5 & 0.85 \\
\hline $\mathrm{J}$ & 4.930 & \pm & 0.027 & 5.0 & 8.1 & 74.8 & 84.3 & 0.87 \\
\hline $\mathrm{K}$ & 4.952 & \pm & 0.037 & 5.5 & 6.2 & 81.0 & 83.2 & 0.93 \\
\hline $\mathrm{L}$ & 5.004 & \pm & 0.043 & 6.0 & 4.8 & 85.8 & 81.6 & 0.98 \\
\hline M & 4.824 & \pm & 0.040 & 7.0 & 5.2 & 91.1 & 76.3 & 1.19 \\
\hline $\mathrm{N}$ & 4.805 & \pm & 0.054 & 8.0 & 4.5 & 95.5 & 71.9 & 1.58 \\
\hline $\mathrm{O}$ & 4.763 & \pm & 0.054 & 9.0 & 4.5 & 100.0 & 71.8 & 2.73 \\
\hline
\end{tabular}

*Plateau: $4.904 \pm 0.015 \mathrm{Ma}$, steps D-K, $78.8 \%$ of the total ${ }^{39} \mathrm{Ar}$ gas released. Irradiation parameter $\mathrm{J}=0.0005205 \pm 0.00000031$.

(continued)

These oldest sedimentary rocks in the map area are exposed near the town of Los Guajes in the eastern wall of the Tecolotlan graben (Plate 1 and Fig. 6A). The total thickness of this unit is not exposed, but it has a minimum thickness of over $400 \mathrm{~m}$. Individual limestone beds are generally thick $(0.5-2 \mathrm{~m})$, dipping $55^{\circ}$ to $70^{\circ} \mathrm{W}$ and striking about $\mathrm{N} 35^{\circ}$ E. Just to the east of Tecolotlan, these limestone beds are folded, with fold axes trending approximately $\mathrm{N} 10^{\circ} \mathrm{E}$ (Ferrari et al., 2000). One small exposure was found within the western footwall in Arroyo La Florida west of the small village of San Buenaventura (Plate 1). In this exposure the limestone is very dark gray, silicified, contains fairly abundant pyrite, and has beds that dip $50^{\circ} \mathrm{NW}$ and strike $\mathrm{N} 50^{\circ} \mathrm{E}$. The silicification of the limestones in Arroyo La Florida is likely related to metasomatism caused by a diorite intrusion that is well exposed farther up this same arroyo. The limestone beds are not exposed within the graben.

Just to the northeast of the mapped area, the limestone is quarried for use in cement production. During quarrying 
Kowallis et al.

TABLE 2. DATA FOR WHOLE ROCK ${ }^{40} \mathrm{Ar}{ }^{39} \mathrm{Ar}$ STEP-HEATING EXPERIMENTS (continued)

\begin{tabular}{|c|c|c|c|c|c|c|c|c|}
\hline Step & $\begin{array}{l}\text { Apparent } \\
\text { age }\end{array}$ & & Error & $\begin{array}{l}\text { Laser } \\
\text { (watt) }\end{array}$ & $\%{ }^{39} \mathrm{Ar}$ & $\begin{array}{c}\text { Cumulative } \\
\%^{39} \mathrm{Ar}\end{array}$ & $\begin{array}{l}\text { \%Radiogenic } \\
{ }^{40} \mathrm{Ar}\end{array}$ & $\mathrm{Ca} / \mathrm{K}$ \\
\hline \multicolumn{9}{|c|}{ JT-K119 (Lab\# 51090) } \\
\hline$A$ & 15.149 & \pm & 37.554 & 0.5 & 0.0 & 0.0 & 4.2 & 1.35 \\
\hline B & 2.363 & \pm & 1.685 & 1.0 & 0.3 & 0.3 & 1.1 & 1.92 \\
\hline $\mathrm{C}$ & 4.553 & \pm & 0.417 & 1.5 & 1.2 & 1.6 & 6.1 & 1.97 \\
\hline $\mathrm{D}$ & 5.211 & \pm & 0.155 & 2.0 & 2.5 & 4.1 & 18.1 & 2.46 \\
\hline E & 5.143 & \pm & 0.075 & 2.5 & 3.9 & 8.0 & 33.4 & 2.73 \\
\hline $\mathrm{F}$ & 5.121 & \pm & 0.043 & 3.0 & 6.4 & 14.4 & 46.4 & 2.39 \\
\hline $\mathrm{G}$ & 5.032 & \pm & 0.029 & 3.5 & 8.4 & 22.8 & 60.7 & 1.83 \\
\hline $\mathrm{H}$ & 4.989 & \pm & 0.023 & 4.0 & 10.4 & 33.2 & 71.1 & 1.32 \\
\hline I & 4.967 & \pm & 0.017 & 4.5 & 11.0 & 44.2 & 79.5 & 1.12 \\
\hline $\mathrm{J}$ & 4.968 & \pm & 0.018 & 5.0 & 9.8 & 54.1 & 83.5 & 1.06 \\
\hline $\mathrm{K}$ & 4.966 & \pm & 0.018 & 5.5 & 8.7 & 62.7 & 84.8 & 1.01 \\
\hline $\mathrm{L}$ & 4.911 & \pm & 0.019 & 6.0 & 6.8 & 69.5 & 85.7 & 0.96 \\
\hline $\mathrm{M}$ & 4.926 & \pm & 0.019 & 7.0 & 7.3 & 76.8 & 87.7 & 0.98 \\
\hline $\mathrm{N}$ & 4.859 & \pm & 0.017 & 8.0 & 6.2 & 83.0 & 87.1 & 1.05 \\
\hline 0 & 4.792 & \pm & 0.026 & 9.0 & 4.6 & 87.6 & 84.0 & 1.45 \\
\hline$P$ & 4.770 & \pm & 0.035 & 10.0 & 3.0 & 90.6 & 82.7 & 2.07 \\
\hline$Q$ & 4.783 & \pm & 0.043 & 11.0 & 2.3 & 92.9 & 81.7 & 2.60 \\
\hline $\mathrm{R}$ & 4.760 & \pm & 0.052 & 12.0 & 1.7 & 94.6 & 79.6 & 3.14 \\
\hline$S$ & 4.621 & \pm & 0.052 & 14.0 & 1.9 & 96.5 & 71.4 & 5.68 \\
\hline $\mathrm{T}$ & 4.476 & \pm & 0.063 & 17.0 & 1.6 & 98.1 & 62.2 & 10.2 \\
\hline U & 4.545 & \pm & 0.099 & 21.0 & 1.0 & 99.0 & 58.8 & 13.0 \\
\hline $\mathrm{V}$ & 4.682 & \pm & 0.102 & 35.0 & 1.0 & 100.0 & 55.5 & 17.4 \\
\hline
\end{tabular}

Irradiation Parameters: All ${ }^{40} \mathrm{Ar} /{ }^{39} \mathrm{Ar}$ analyses are calculated using an age of $28.02 \mathrm{Ma}$ (Renne et al., 1998) for the co-irradiated monitor mineral Fish Canyon Sanidine. Irradiation parameter $\mathrm{J}$ is calculated based on multiple analyses of individual grains from multiple locations on the irradiation disks to account for variations in reactor irradiation gradients, thus values for $\mathrm{J}$ are listed above for each sample. ${ }^{40} \mathrm{Ar} /{ }^{36} \mathrm{Ar}$ mass discrimination $=1.007 \pm 0.001$; isotope interference corrections used are $\mathrm{Ca}{ }^{39} \mathrm{Ar} /{ }^{37} \mathrm{Ar}=0.00076 \pm 0.000056$, $\mathrm{Ca}^{36} \mathrm{Ar} /{ }^{37} \mathrm{Ar}=0.00027 \pm 0.00001$, and $\mathrm{K}^{40} \mathrm{Ar} /{ }^{39} \mathrm{Ar}=0.00014 \pm 0.00006$

Note: The mean square of weighted deviates associated with our isochron fits are slightly larger than would be expected, indicating slightly more scatter around our fit than expected from the small uncertainties accompanying the plateau and isochron ages. This most likely indicates that we have underestimated the actual uncertainty associated with one or more parameters ( $\mathrm{J}$, discrimination, etc.) associated with the individual increment ages. However, the congruence between the plateau, isochron and integrated ages indicate that this has not affected the age in either of the calculations or our confidence in our overall calculated age of the samples.

operations, late Pleistocene mammals, including horse (Equus sp.) and camel (?Hemiauchenia), were discovered by quarry workers within a small cave in these limestones.

\section{Formation of Juchitlan (Late Cretaceous-Kj)}

Altered rhyolitic to dacitic ash-flow tuffs (ignimbrites), trachyandesitic lava flows, and volcaniclastic sedimentary rocks comprise the formation of Juchitlan (Plate 1 and Fig. 7). The color of the different volcanic and sedimentary units of this formation is quite variable. Immediately west of Juchitlan, Mexico Highway 80 climbs up through the western escarpment of the graben. Here, in several road cuts, are good exposures of these rocks (Plate 1). The exposed thickness of this formation is $\sim 300 \mathrm{~m}$, however, a complete section is nowhere exposed in the mapped area. The lower part of the formation is comprised of a succession of fine-grained red beds, volcaniclastic sandstones, and channel fill deposits. These are overlain by a section dominated by ash-flow tuffs and lava flows separated by thick lahar deposits (Plate 1). The formation of Juchitlan probably correlates to "unit 1" (Late Cretaceous volcanic and sedimentary rocks) described by Ferrari et al. (2000) in their geologic map just north of this area. The descriptions by Martini et al. (2010) of the Late Cretaceous Zihuatanejo and La Union Formations of southwestern Mexico are very similar to our formation of Juchitlan with volcaniclastic conglomerates, red-beds composed of sandstones (feldspathic litharenites) and siltstones, and meter- to decimeter-thick layers of tuff and lava flows. The lower, mostly sedimentary rock section of this formation contains sandstones, siltstones, and volcaniclastic conglomerates that appear to be mostly fluvial and overbank deposits. The sandstones are lithic 


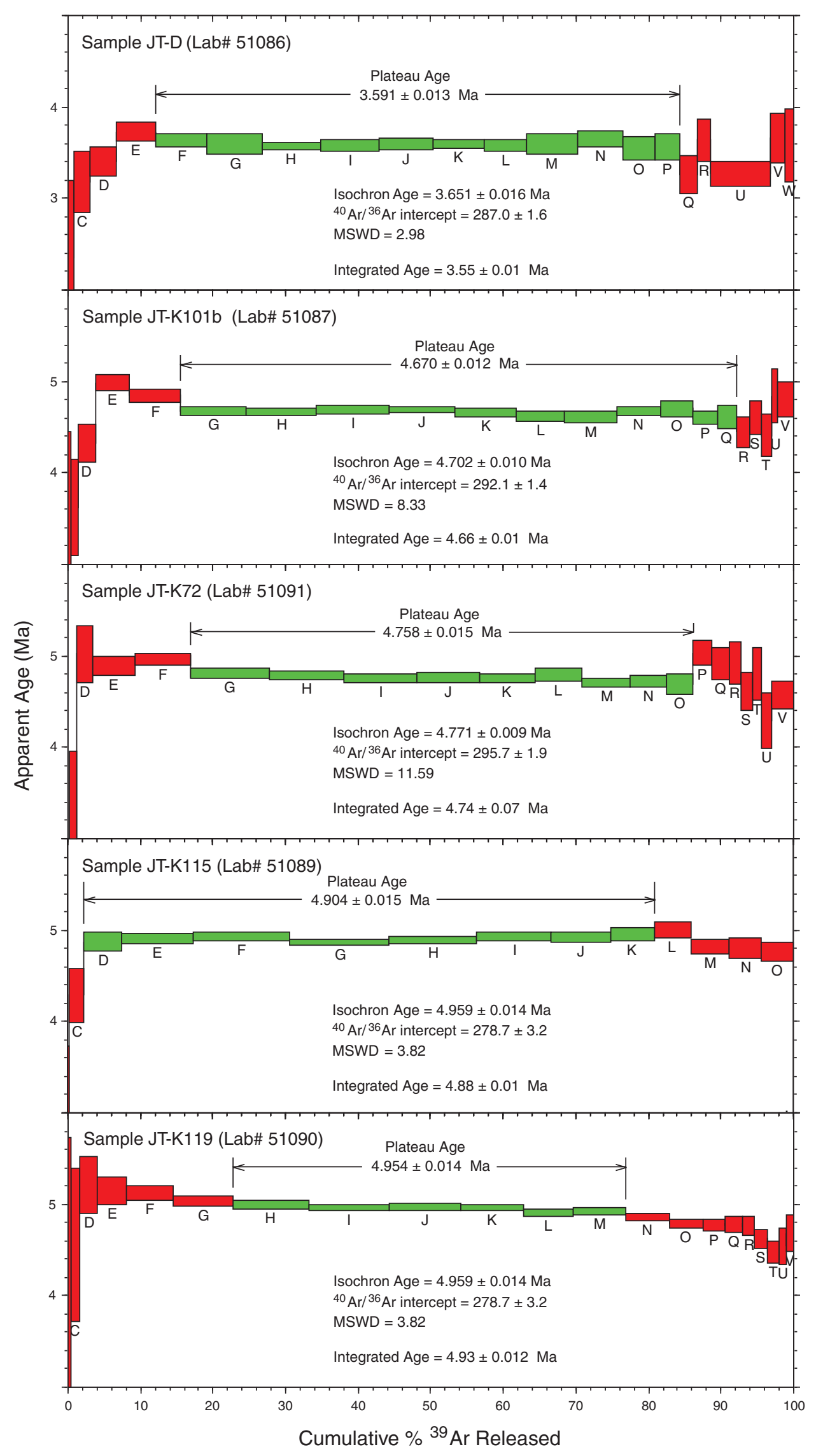

Figure $3 .{ }^{40} \mathrm{Ar} /{ }^{39} \mathrm{Ar}$ age spectra for wholerock analyses of mafic lavas from the formation of San Jose. The plateau ages are the ages reported in Table 1. MSWDmean square of weighted deviates. 


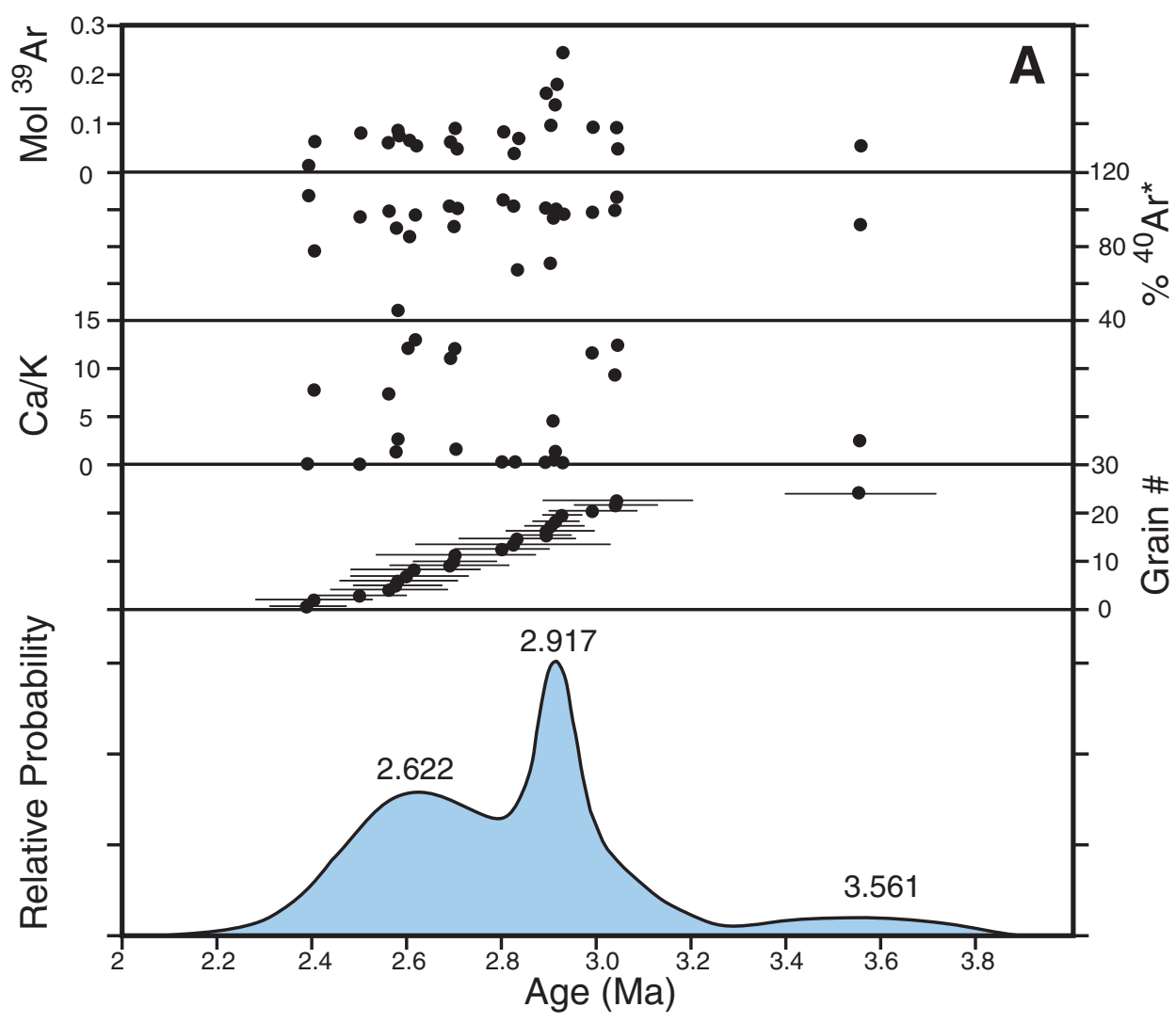

Figure $4 .{ }^{40} \mathrm{Ar} /{ }^{39} \mathrm{Ar}$ laser probe age spectra for sanidine analyses from (A) a Neogene fallout tuff from the formation of San Buenaventura (JT-K107) and (B) a Cretaceous ash-flow tuff (B) (JT-K42) from the formation of Juchitlan. The Cretaceous sample had two spurious younger grains, but the main population of grains fall at ca. $77 \mathrm{Ma}$.

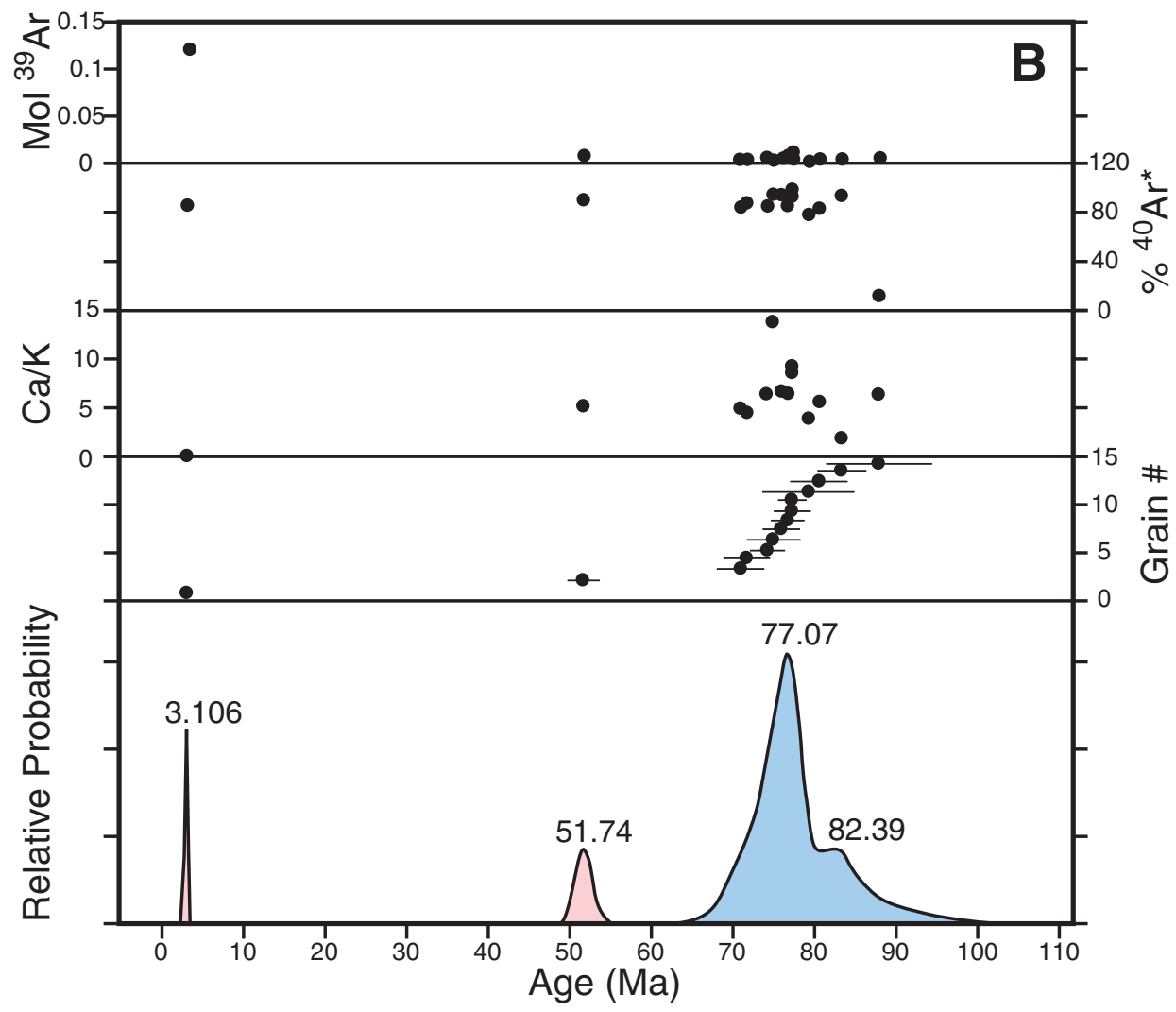




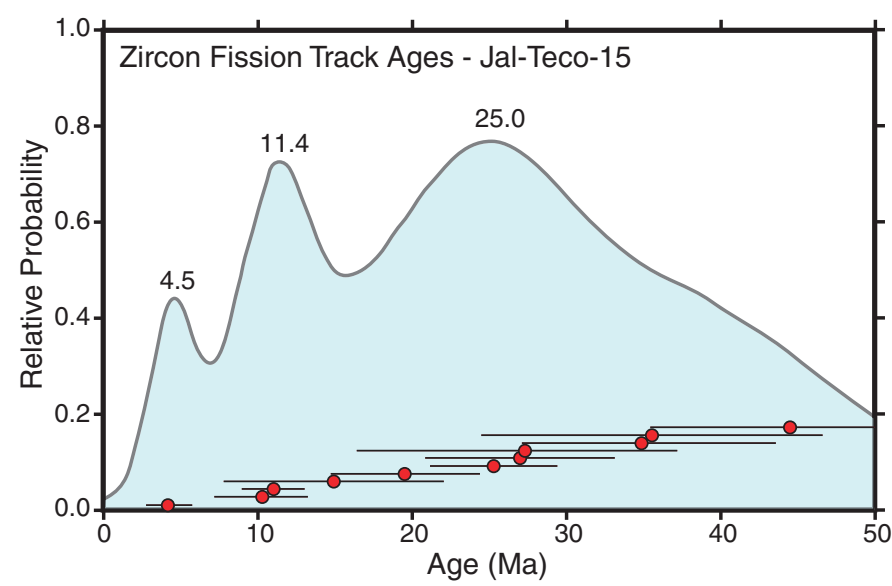

Figure 5. Relative probability plot of detrital zircon fission track ages from a sandy layer (JT-15) in the formation of San Jose.

arkoses (classification of Folk, 1974) or feldspathic arenites and feldspathic wackes (classification of Dott, 1964, see Figs. 8 and 9). Below the rhyolite dome of Cerro Chipahua (near location 4 on the geologic map), these sedimentary rocks are brick red siltstones and fine-grained sandstones that dip $\sim 20^{\circ} \mathrm{W}$ and strike $\mathrm{N} 15^{\circ} \mathrm{E}$ (Fig. 10). The red color indicates an oxidizing environment of deposition in fairly quite water, likely overbank fluvial deposits. No obvious sedimentary structures, such as ripples, mud cracks, etc., were observed in these outcrops. Some coarser layers of pebble conglomerate also occur here with the pebbles composed of volcanic rock fragments.

Farther to the south, west of the town of San Jose (between localities $148-151$ on the geologic map), we measured a partial section of $\sim 50 \mathrm{~m}$ thickness through the sedimentary part of this formation where it dips $\sim 20^{\circ}$ west and strikes N $45-65^{\circ}$ E. Here the sandstones and siltstones are brick red to lavender to grayish brown with angular to subrounded grains. They often have a "salt and pepper" appearance through a hand lens being composed mostly of mafic volcanic rock fragments and light feldspar with minor quartz. Cement is a combination of calcite, clay, and quartz (Fig. 9). Occasionally beds contain dark lavender mudstone ripup clasts. These sediments are mostly overbank fluvial deposits with pale orange to pale greenish yellow, cross-bedded channel sandstones (perhaps point bar deposits) cutting into them. The channel sandstones are typically more resistant and form small cliffs ranging in thickness from $\sim 1 \mathrm{~m}$ to over $10 \mathrm{~m}$.

Within the upper volcaniclastic complex are at least six subaerial ignimbrites, ranging in thickness from 3 to $20 \mathrm{~m}$, interbedded with mafic to intermediate composition lava flows, and volcaniclastic conglomerates (interpreted to be lahar deposits).

Lahar units tend to be dark grayish red to dark brownish purple, and occasionally pale green to grayish green. They are mostly matrix supported conglomerates, well lithified, and composed of angular to subrounded, weathered volcanic lithic fragments ( $60 \%-70 \%$ of a typical outcrop ranging in size up to $0.5 \mathrm{~m}$ diameter) and a fine-grained matrix $(\sim 30 \%-40 \%)$ that con- tains variable amounts of feldspar, quartz, hornblende, biotite, pyroxene, calcite, and clay. The volcanic lithic fragments were not chemically analyzed, but appear to be mostly intermediate to mafic in composition and similar to the interbedded lava flows mentioned above. Rare sedimentary lithic fragments (mostly sandstone) are also present.

The volcanic rocks of the formation of Juchitlan are dominantly silicic ignimbrites with only small preserved volumes of trachyandesitic and trachybasaltic lava flows (Table 3 and Fig. 11). This contrasts with the nearby Chiquilistlán area $(\sim 20 \mathrm{~km}$ east) where felsic lava flows dominate the Cretaceous volcanic section (Freydier et al., 1997), but it is similar to the Playa AzulSan Juan de Lima area ( 200 km southeast) where subaerial ignimbrites are common (Tardy et al., 1994). They are all generally thin outflow units (all but one less than $10 \mathrm{~m}$ ) and can be distinguished by phenocryst content, color, and abundance of lithics. The ignimbrites are also more resistant than the surrounding volcaniclastic rocks so that they form small cliffs (Fig. 6B). They are designated as tuffs A-F, from oldest to youngest (Fig. 7). These volcanic units are described in more detail here because their distinctive character and mineralogy may allow them to be used in correlation beyond the Tecolotlan area and because their nature has important implications for the character of the Cretaceous arc. These tuffs, as well as some intercalated lava flows, are described here from outcrops along Mexico Highway 80 west of Juchitlan (localities 30, 35-42 on the geologic map) and from outcrops below Cerro La Coronilla northwest of Juchitlan (near localities 76 and 87-88 on the geologic map).

The oldest volcanic unit is an altered lava flow or ash-flow tuff (JT-K76) that occurs near the base of the exposed part of the section below Cerro La Coronilla. This unit is porous, pinkish gray, with highly altered phenocrysts and is $\sim 2 \mathrm{~m}$ thick.

Tuff A (JT-K42) is a light gray to pinkish gray, crystal-rich, welded rhyolite tuff. Pumice fragments are flattened into thin black glassy stringers. This unit is $\sim 7 \mathrm{~m}$ thick. It contains $10 \%-$ $15 \%$ volcanic lithic fragments, mostly aphanitic and brick red in color. Phenocrysts of plagioclase (17\%) and sanidine (8\%) are mostly altered and range in size up to $3 \mathrm{~mm}$. Enough unaltered plagioclase grains were extracted from this unit to obtain an age of $77.0 \pm 0.5 \mathrm{Ma}$.

Tuff B (JT-K41) is a pinkish brown, moderately welded rhyolite ash-flow tuff $\sim 4-5 \mathrm{~m}$ thick. This unit contains $\sim 1-2 \%$ lithic fragments and $\sim 3 \%$ plagioclase phenocrysts up to $0.5 \mathrm{~mm}$ in size. Relict glass shards are obvious in thin section.

Tuff C (JT-K40) is a pinkish brown, moderately welded rhyolite tuff, similar to tuff B but without lithic fragments and with sanidine phenocrysts. It is $\sim 4-5 \mathrm{~m}$ thick. Obvious altered glass shards in thin section make up most of the groundmass. Lithic fragments were not observed, but the unit has $\sim 3 \%$ plagioclase and $2 \%$ sanidine phenocrysts (up to $2 \mathrm{~mm}$ ), both extensively altered. Rare, small (a few $\mathrm{mm}$ ), pumice fragments are altered to a light green color.

Tuff D (JT-K38) is a mottled light green to pink, crystal-poor, lithic-rich rhyolite tuff $\sim 15-20 \mathrm{~m}$ thick. Volcanic lithic fragments 


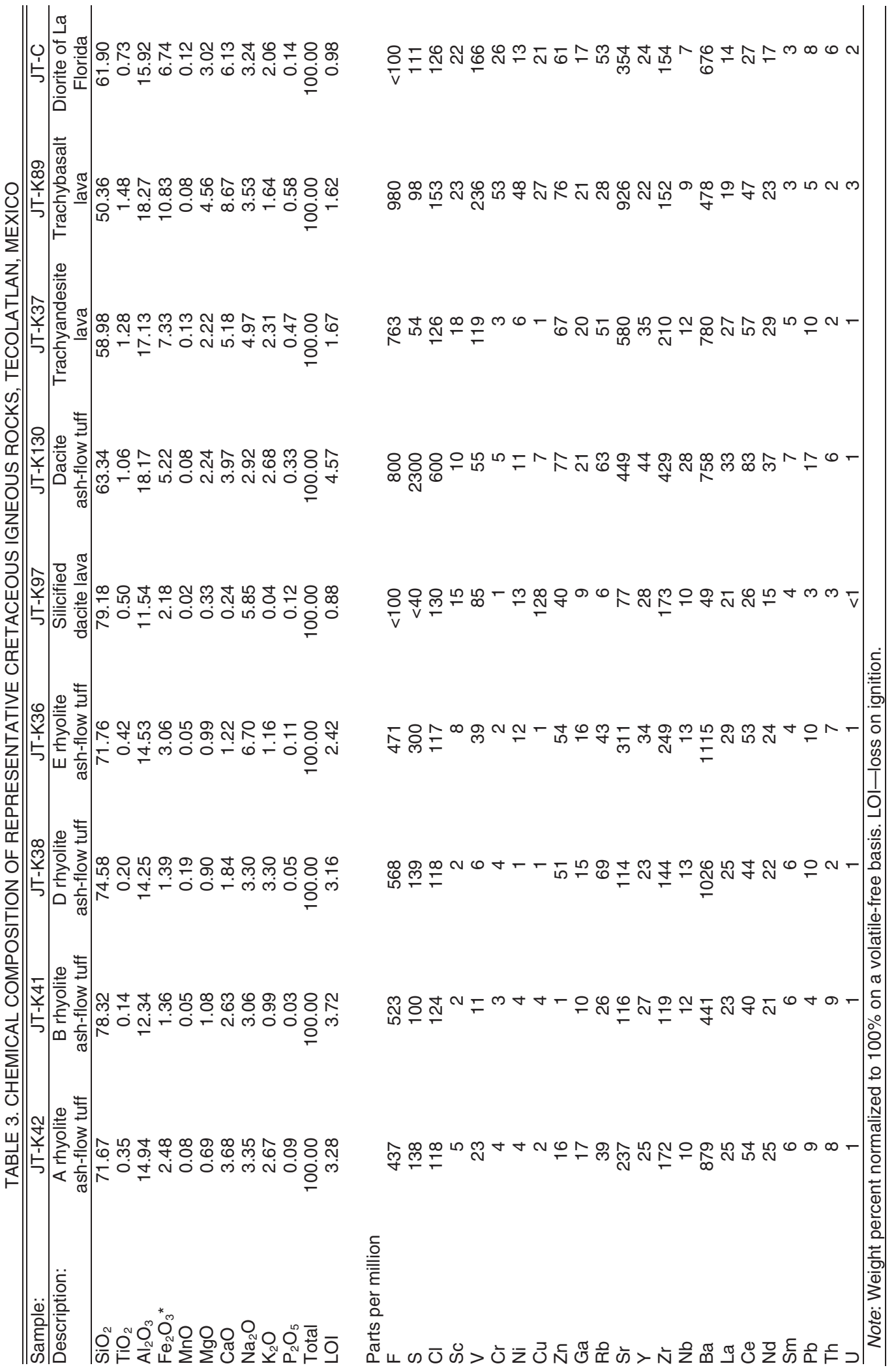



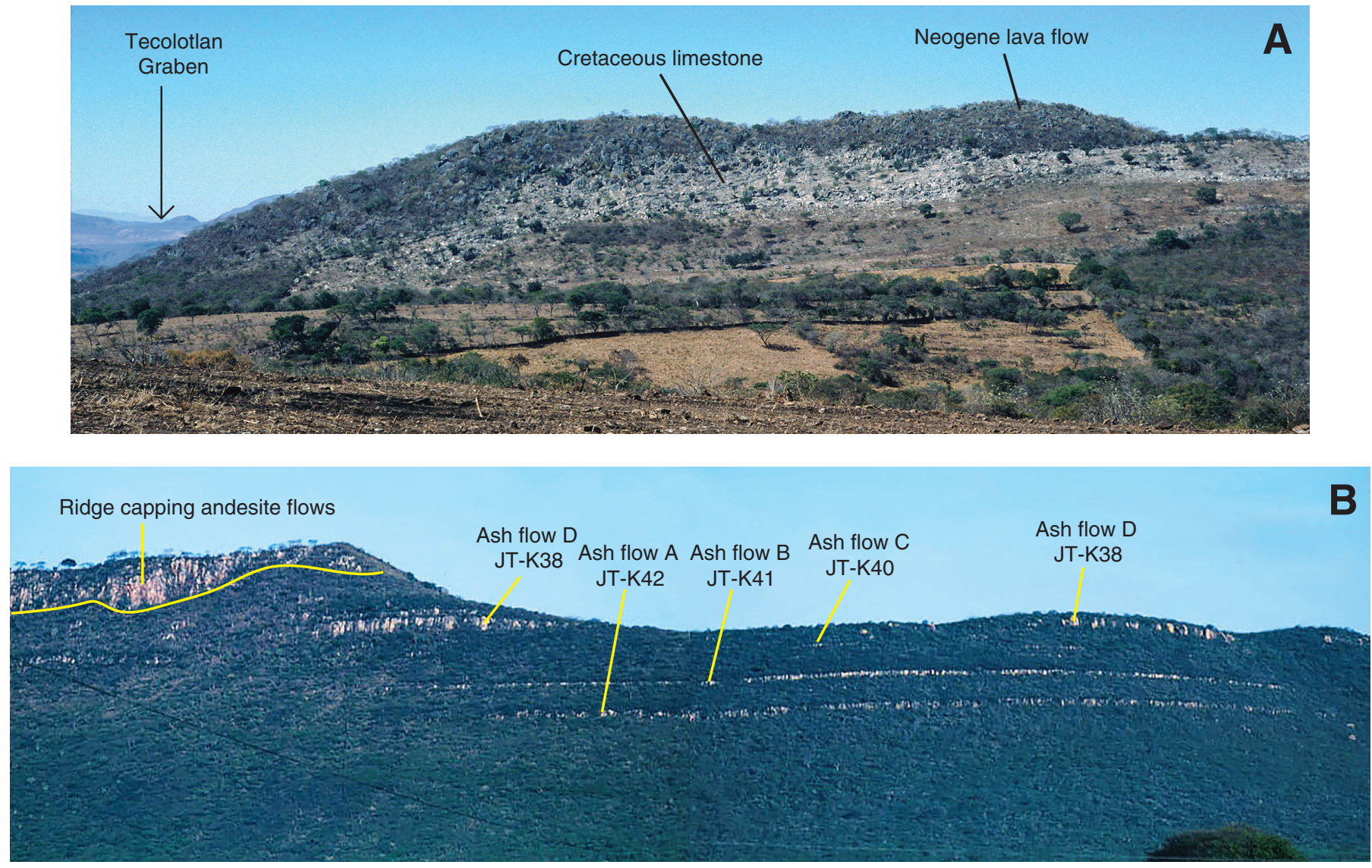

Figure 6. (A) View looking to the west from approximately locality \#128 on Plate 1. The ridge is capped by a Neogene lava flow (dark gray) and underlain by Cretaceous limestone (light gray). The Tecolotlan graben lies over the ridge to the west. (B) View to the west of the western horst of the graben showing ridge capping Neogene andesite lava flows over Cretaceous volcaniclastic sediments and tuffs of the formation of Juchitlan.

comprise $\sim 30 \%-40 \%$ of the tuff, with pumice fragments $\sim 15 \%$. Less than $1 \%$ of the tuff is phenocrysts of plagioclase and sanidine (up to $1 \mathrm{~mm}$ ). This tuff forms the uppermost and largest cliff of any of the ash-flow tuffs in the western escarpment. This tuff also forms a dip slope west of the escarpment near Los Tepetates on the western margin of the geologic map (Plate 1).

A trachyandesite lava flow (JT-K37) overlies tuff D. It is dark gray on fresh surfaces with some altered greenish patches. Plagioclase phenocrysts can be seen with a hand lens. The flow is $\sim 10 \mathrm{~m}$ thick.

Tuff E (JT-K36) is a welded, pinkish brown, rhyolite tuff with obvious pumice fragments and is $\sim 6 \mathrm{~m}$ thick. Pumice fragments have been altered to pale green. Phenocrysts are larger (up to $2 \mathrm{~mm}$ ) and more abundant than in tuff $\mathrm{F}$ with $\sim 8 \%$ plagioclase phenocrysts and $5 \%$ sanidine phenocrysts. It also contains $\sim 5 \%$ volcanic lithic fragments. A tuff with similar color, texture, mineralogy, lithic and pumice content outcrops within the graben along Arroyo Tamazula near the village of Santa Maria (Plate 1), central part of map area) and may be correlative.

Tuff F (JT-K35) is a whitish gray to light gray, rhyolite tuff with poorly welded, "punky" upper third and a more densely welded base (but not quite a vitrophyre). It is $\sim 3 \mathrm{~m}$ thick and contains $\sim 5 \%$ volcanic lithic fragments and $7 \%$ altered plagioclase phenocrysts (up to $1 \mathrm{~mm}$ ).

Near the top of the pass along Mexico Highway 80 is another trachyandesite lava flow (JT-K30) 2 m thick located just outside of the area of Plate 1. It is dark gray with prominent plagioclase phenocrysts (up to $0.5 \mathrm{~mm}$ ) and vugs filled with calcite. The larger phenocrysts have been altered and replaced by calcite.

The three lava flows in this formation are typically porphyritic with phenocrysts of plagioclase as well as clinopyroxene, and less common hornblende. They are all trachyandesites (Fig. 11). Similar intermediate lavas were sampled in other parts of the formation. One silicified dacite lava (JT-K97; Table 3) was also found in the formation of Juchitlan just outside of the map area to the northeast on the road from Ojo de Agua to Tamazulita. At this locality the formation dips $55^{\circ}$ west and striking $\mathrm{N} 10^{\circ} \mathrm{W}$.

While no evidence of fossil animals (vertebrate or invertebrate) was found in these beds, fossil wood was discovered in one small area. The wood consisted of short tree segments along bedding planes or, in some cases, bases of trees that appeared to be in situ with some preserved root systems. Dr. Sergio Cevallos 


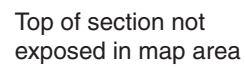

Top of section not

exposed in map area

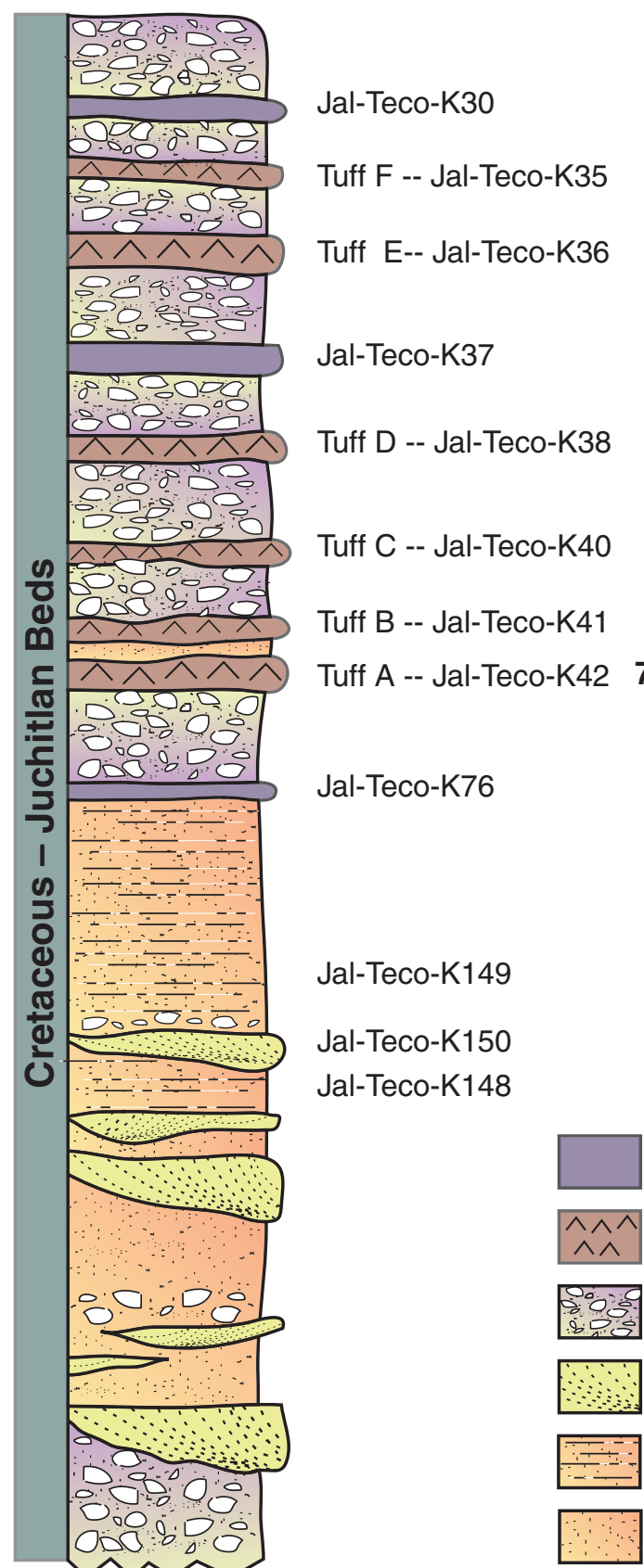

Figure 7. Schematic section of the Cretaceous formation of Juchitlan as exposed in the western horst of the Tecolotlan graben.
Lava flows

Ash-flow tuffs

Volcanic breccia, lahar deposits

Sandstone, channel fill

Redbeds, mudstones, siltstones and sandstones

Volcanic siltstone and sandstone

Bottom of section not exposed in map area

(Instituto de Geología at the Universidad Nacional Autónoma de México) has tentatively identified these fossils as palm wood.

The $77 \mathrm{Ma}$ age of Tuff A dates this formation to the Late Cretaceous Campanian age. Previous work by Wallace and Carmichael (1989), Righter and Rosas-Elguera (2001); and Frey et al. (2007) have also examined the Cretaceous volcanic rocks near the Tecolotlan graben. Righter and Rosas-Elguera (2001) described an older "greenish to violet colored andesite breccia" that they called the Jalisco breccia. Overlying these volcaniclastic rocks, an age of $79 \mathrm{Ma}$ was obtained on a rhyolite ash-flow tuff (Rosas-Elguera et al., 1997), comparable to our age of $77 \mathrm{Ma}$. A Late Cretaceous age for these ignimbrites and sedimentary rocks 

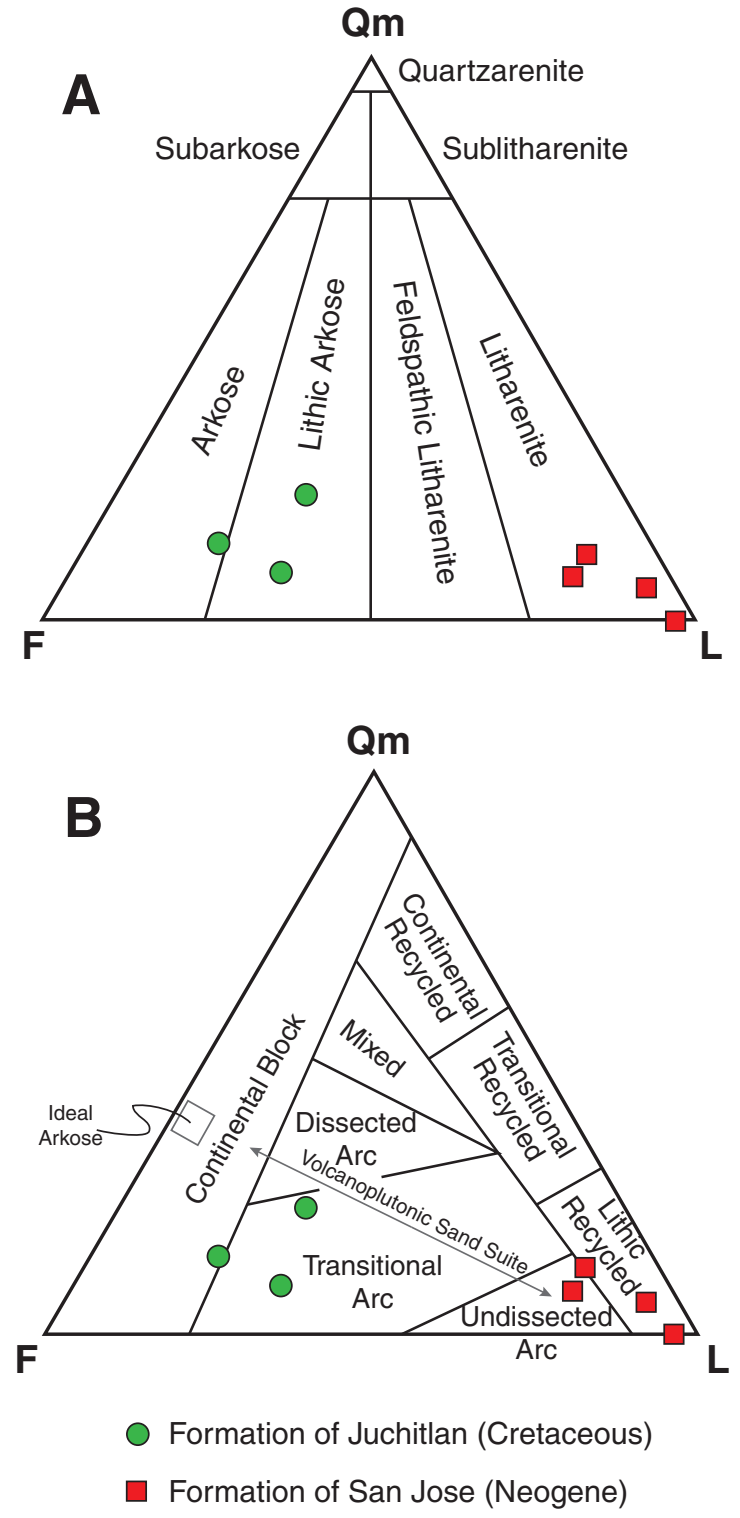

Figure 8. Classification diagrams for the sandstones of the formations of Juchitlan (Cretaceous) and San Jose (Neogene). (A) QmFL composition (monocrystalline quartzfeldspar-lithics) and (B) provenance diagrams. Compositional fields are from Folk (1974) and provenance-fields are from Dickinson (1985).

is expected for the Jalisco block (Köhler et al., 1988; Wallace and Carmichael, 1989; Allan et al., 1991; Righter et al., 1995; Frey et al., 2007) and these tuffs and lavas correlate with the volcanic part of the Lower Volcanic Complex of the Sierra Madre Occidental (McDowell and Keizer, 1977), particularly with the Tarahumara Formation of McDowell et al. (2001). This succession of volcanic and sedimentary rocks is younger than similar rocks of the Guerrero terrane described by Tardy et al. (1994) and Freydier et al. (1997), which are thought to be Late Jurassic to Early Cretaceous.

\section{Diorite of La Florida (Cretaceous?-Kd)}

Cropping out in the northwest corner of the map area (Plate 1) is a diorite pluton that intrudes the Juchitlan beds and has metamorphosed and silicified the limestone of Los Guajes in Arroyo La Florida. The pluton is medium gray with a uniform crystal size of 1-2 mm. Mineralogically, the pluton is composed of $\sim 38 \%$ plagioclase, $25 \%$ quartz, $17 \%$ hornblende, $11 \%$ biotite, and $6 \%$ K-feldspar. Accessory apatite and Fe-oxides are also present. Chlorite and sericite alteration occur throughout. Chemically, the rock is a diorite with 63\% silica (Fig. 11). This intrusion is probably related to numerous other Late Cretaceous to Paleocene plutons found in the Jalisco block and lumped together as the Puerto Vallarta batholith (Ferrari et al., 2000). More recent work has shown that these Late Cretaceous to Paleocene diorites and granites range in age from 59 to $92 \mathrm{Ma}$ (Valencia et al., 2013). Field relations constrain the diorite of La Florida to younger than $77 \mathrm{Ma}$ as it intrudes the formation of Juchitlan.

\section{Geochemistry of the Cretaceous Igneous Rocks}

The Cretaceous volcanic rocks are typically altered, especially the felsic ignimbrites. To avoid problems with mobile elements, we focus most of our interpretations for these older rocks on less mobile, high-field-strength elements such as Ti, $\mathrm{Zr}, \mathrm{Nb}, \mathrm{Y}$, and rare earth elements (REE) (e.g., Winchester and Floyd, 1977) and the phenocryst assemblage. Using the elemental compositions, the original rock types include basalt, andesite, and rhyolite (Fig. 11).

The felsic rocks are most altered - as noted above quartz and feldspar phenocrysts have survived in some. Chemically the alteration is apparent in low values for $\mathrm{K}_{2} \mathrm{O}$ (and $\mathrm{Rb}$ ) and perturbed $\mathrm{Na}_{2} \mathrm{O}$, some high and some low (Table 3 and Supplemental Tables 1 and $2^{1}$ ). Most of the felsic volcanic rocks are silicified; some have as much as $83 \% \mathrm{wt} \% \mathrm{SiO}_{2}$ on an anhydrous basis. Many of the altered rocks also have high LOI (loss on ignition at $1000{ }^{\circ} \mathrm{C}$ ); this value ranges to as much as $5 \%$. Rhyolites are identified using immobile elements as those with less than $0.4 \%$ $\mathrm{TiO}_{2}$ and high $\mathrm{Zr} / \mathrm{Ti}$ ratios (Fig. 11) and dacites with between 0.4 and $0.6 \% \mathrm{TiO}_{2}$.

On mantle-normalized trace-element diagrams, almost all of the Cretaceous rhyolites have strong enrichment of large ion lithophile elements (LILE), $\mathrm{Nb}$-Ti depletions, and $\mathrm{Pb}$ enrichments, consistent with derivation from a subduction zone (Fig. 12). High $\mathrm{La} / \mathrm{Nb}$ ratios $(>1)$ and $\mathrm{Ba} / \mathrm{Nb}(>40)$ are consistent with this interpretation. They are also light rare earth element (LREE) enriched (Fig. 12), an enrichment characteristic of calc-alkaline suites. The high $\mathrm{La} / \mathrm{Y}$ ratios are more consistent with generation in a continental arc than in an island arc (Gill, 1981). The $\mathrm{Sr}$ and $\mathrm{P}$ depletions on normalized diagrams are probably the result of fractional crystallization at low pressure and the removal of

${ }^{1}$ GSA Data Repository item 2017112, Supplemental Tables 1 and 2, is available at http://www.geosociety.org/pubs/ft2017.htm or by request to editing@ geosociety.org. 


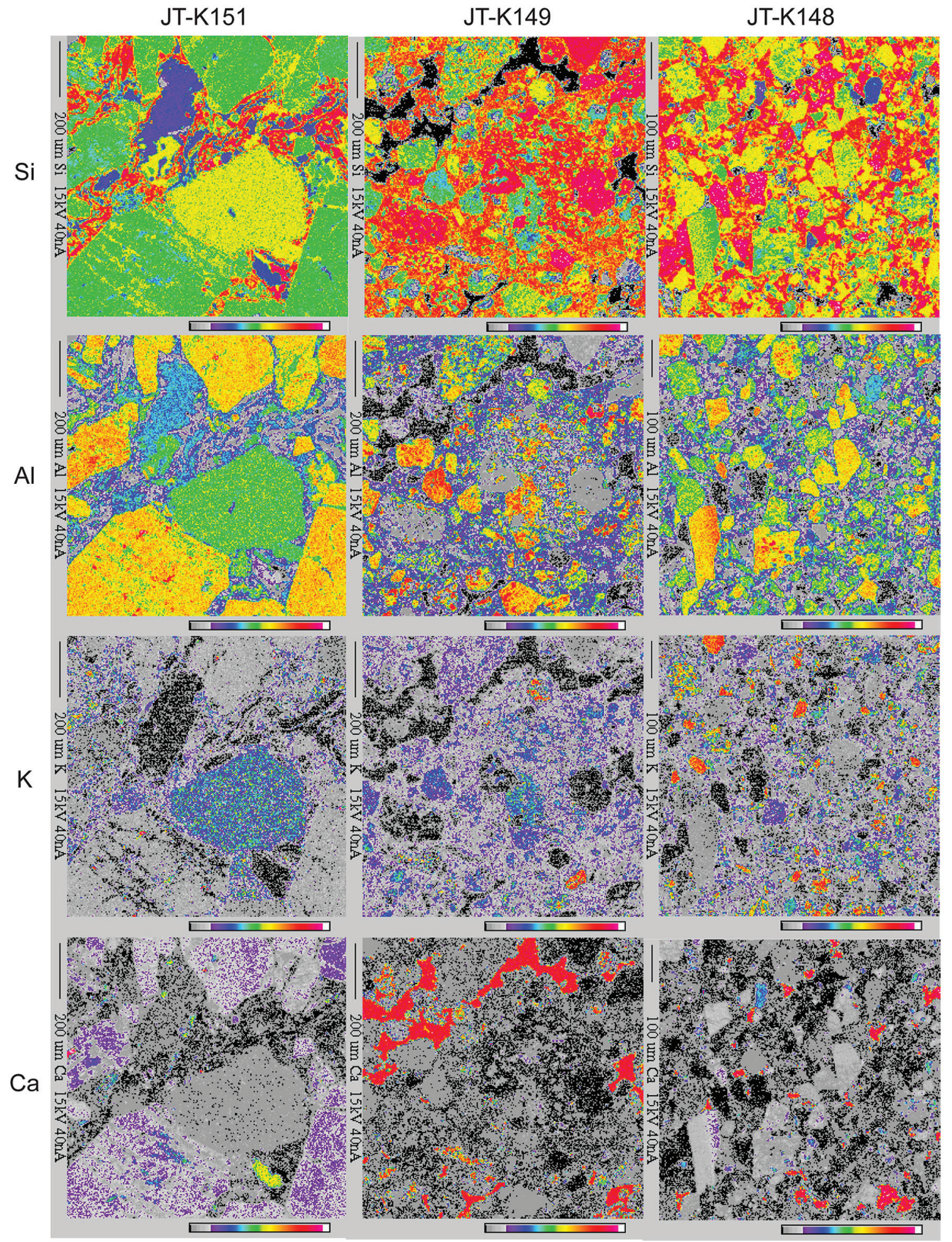

Figure 9. Element maps for three sandstones from the Cretaceous Juchitlan formation. Each image is $\sim 1000$ microns wide. Element abundances are highest at the red end of the scale and lowest in black. The Al, K, and Ca maps show the presence of abundant feldspar, both plagioclase and K-feldspar. Clay and quartz between the grains are the main cementing materials (note the abundant blue between grains in the Al maps and the reds in the Si maps). Some calcite cement is also present in two of the samples (the bright reds in the Ca maps). Quartz grains do not appear to comprise more than $25 \%-30 \%$ of the grains in any of the samples (see the $\mathrm{Al}$ maps where the gray areas are mostly quartz grains or quartz cement), with sample JT-K149 having the most quartz. 

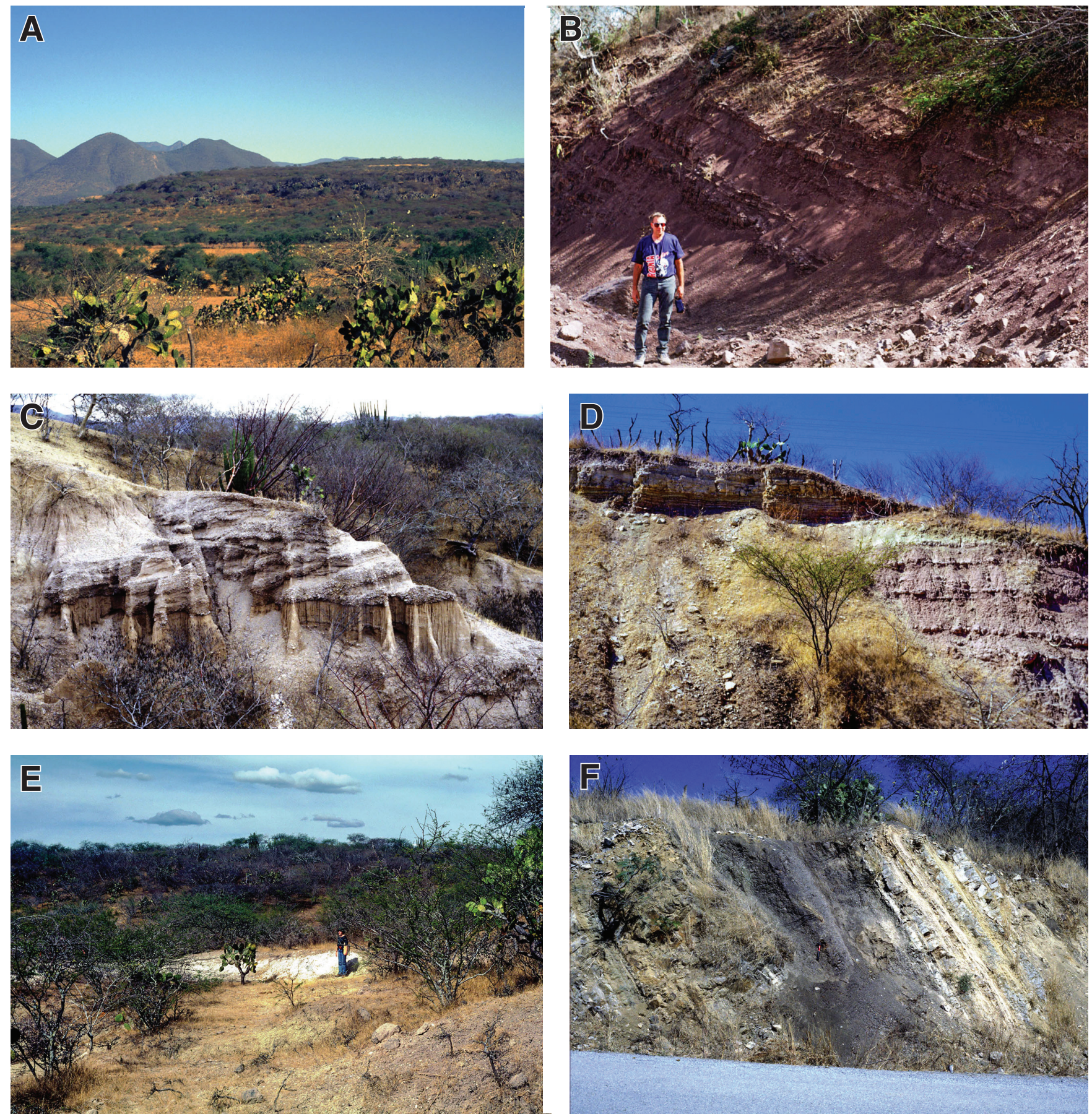

Figure 10. (A) View to the northwest. Low hill in middle distance is a mafic lava flow (Tm) surrounded by rocks of the formations of San Jose and San Buenaventura. Distant hills are capped by thick rhyolite lava flow ( Tr) and underlain by the Cretaceous formation of Juchitlan (Kj). (B) Reddish sandstones and siltstones of the Cretaceous formation of Juchitlan (Kj) near point \#4 on geologic map at base of hills capped with rhyolite flows ( $\mathrm{Tr}$ ) seen in photo A. Here the rocks dip $20^{\circ}$ to the west. (C) Coarse cross-bedded fluvial and alluvial sediments of the formation of San Buenaventura (QTsb, Blancan-Irvingtonian) lying unconformably on the finer grained beds in the formation of San Jose (Tsj, Hemphillian). (D) Formation of San Jose (Tsj) in road cut along Mexico Highway $80 \sim 10 \mathrm{~km}$ south of Tecolotlan. Exposed section is $\sim 10 \mathrm{~m}$ thick. The uppermost layers (top 1-2 m) are sandy carbonate lacustrine beds, while the rest of the exposure is composed of silty mudstone and interpreted to be fluvial and overbank deposits. (E) Locality of ash bed JT-K18 (or Jal-Teco-20 of Kowallis et al., 1998) in the formation of San Jose. (F) Tilted beds of the limestone of Los Guajes along the road to the quarry located just outside the map area to the northeast. Hammer for scale. The beds here dip $55^{\circ}$ to the west. 

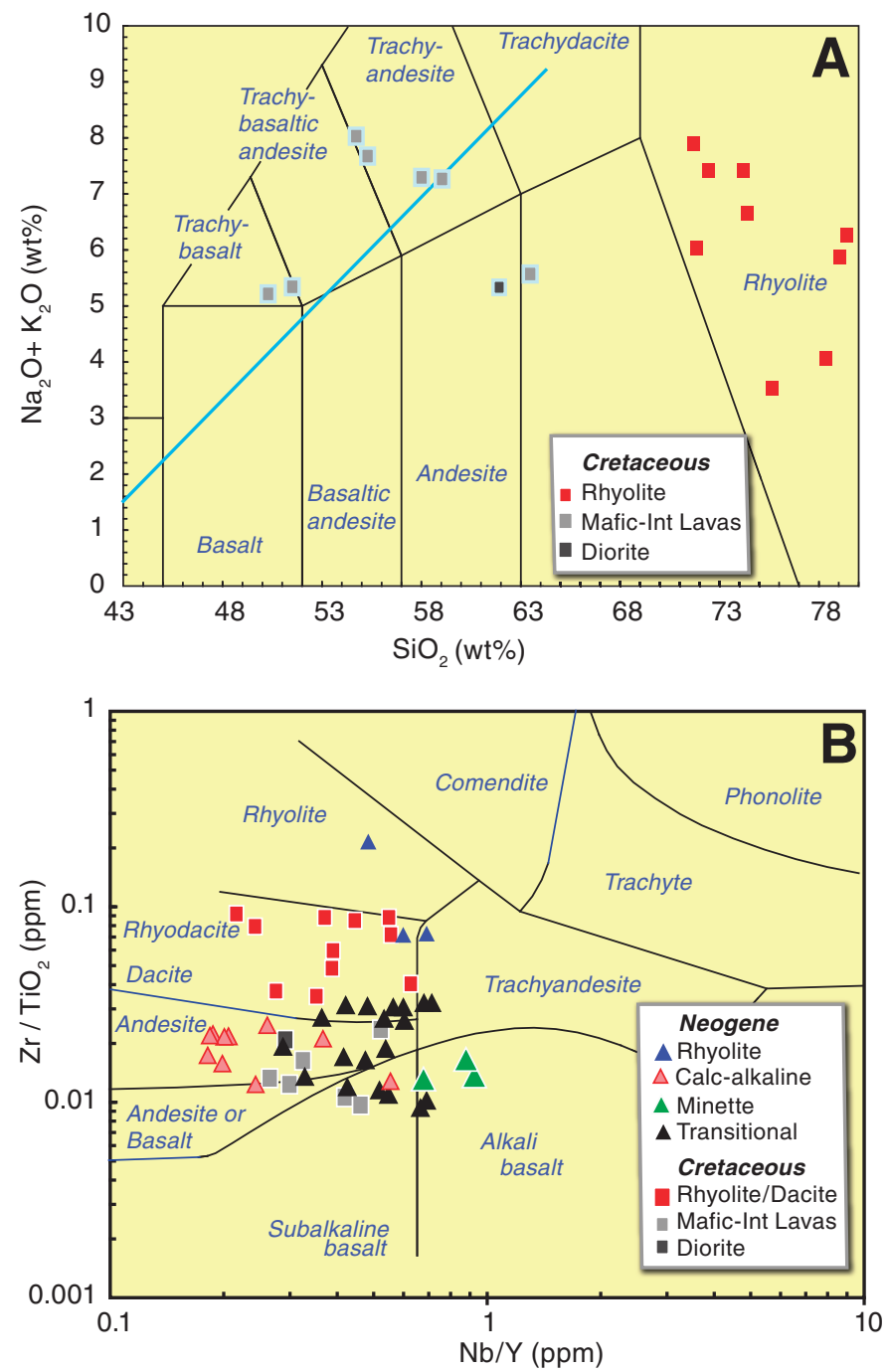

Figure 11. Chemical compositions of the Cretaceous igneous rocks of the Tecolotlan area. (A) Total alkali-silica classification diagram (Le Maitre, 1989). The rhyolites are altered and have low alkali contents. (B) $\mathrm{Nb} / \mathrm{Y}-\mathrm{Zr} / \mathrm{TiO}_{2}$ ratios confirm the presence of Cretaceous basalts, andesites, and rhyolites (after Winchester and Floyd, 1977). This diagram distinguishes dacites from andesites more effectively than does Pearce's (1996) revision as judged by the compositions of the fresh Neogene rocks.

feldspars and apatite. Ti depletions were accentuated by fractionation of Fe-Ti oxides. The rhyolites mostly plot within the volcanic arc field of Pearce et al. (1984) (Fig. 12). A notable exception is a "dacitic" ash-flow tuff (JT-K130) that has high concentrations of $\mathrm{Zr}$ and plots in the within plate granite (WPG) field. In most regards, these silicic rocks are similar to the Type $\mathrm{V}$ rhyolites of Playa Azul identified by Tardy et al. (1994). They found that silicic volcanic rocks were rare in the Guerrero terrane; but they are common in the vicinity of Tecolotlan.

The mafic and intermediate composition volcanic rocks in this sequence are less geochemically altered. They contain
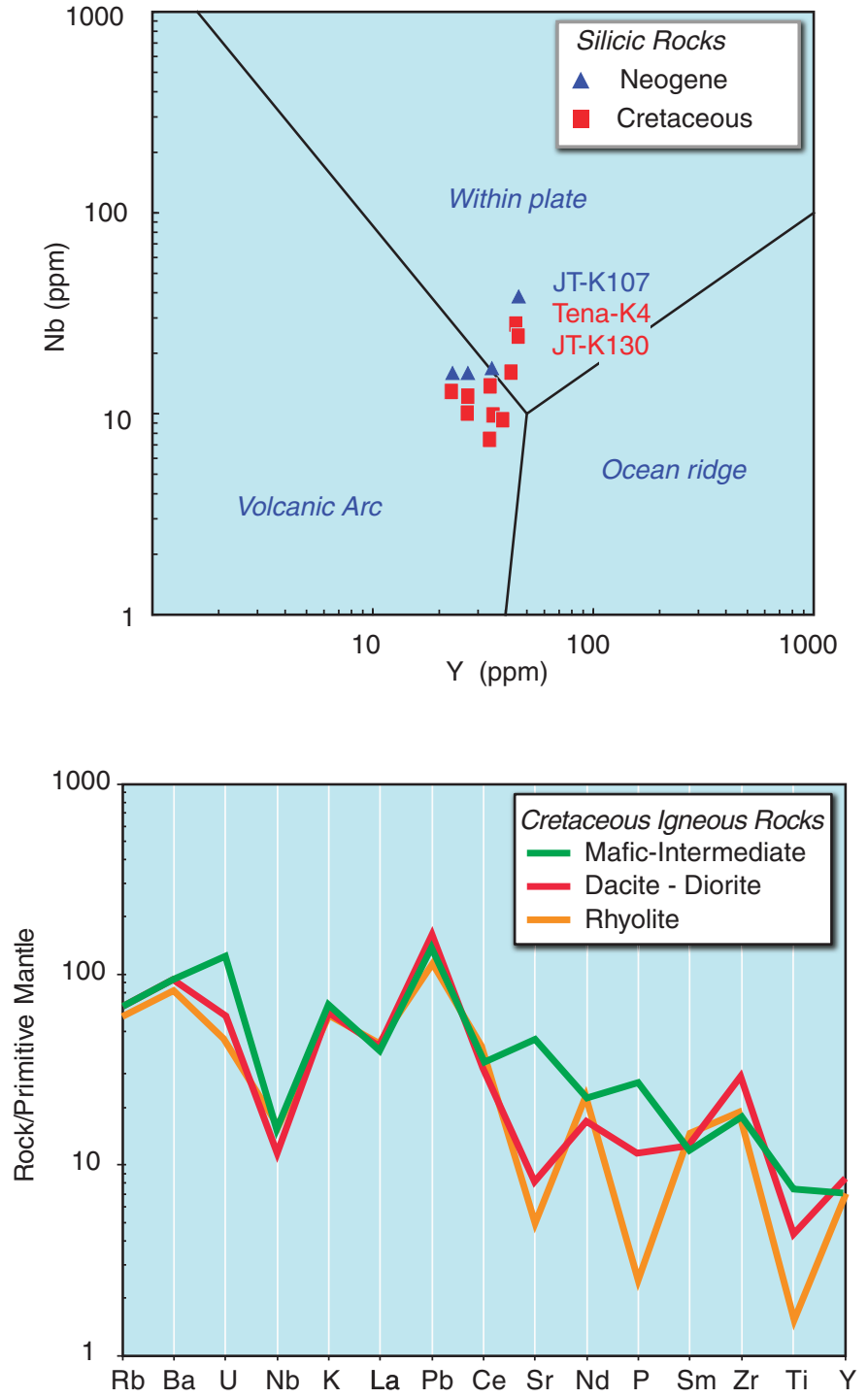

Figure 12. Trace element compositions of Cretaceous igneous rocks from the Tecolotlan graben. (A) Tectonic discrimination diagram of Pearce et al. (1984). Both Cretaceous and Neogene silicic rocks are plotted. The high $\mathrm{Nb}$ and $\mathrm{Y}$ concentrations in two of the Cretaceous samples are probably the result of alteration. JT-K107 is a distal fallout tuff and also strongly altered. (B) Average trace element patterns for Cretaceous igneous rocks all show negative $\mathrm{Nb}$-anomalies, positive $\mathrm{Pb}$ anomalies and enrichments in LILE. Normalization values for primitive mantle are from Sun and McDonough (1989).

altered phenocrysts of plagioclase in a dark groundmass that was probably composed of plagioclase, pyroxene, Fe-oxides, and perhaps olivine. Secondary calcite, Fe-oxides, and clays have replaced much of the matrix and most of the phenocrysts. They range from trachybasalt to trachyandesite in composition (Fig. 11). If $\mathrm{K}$ has not been disturbed, they are part of a medium- to high-K suite. $\mathrm{P}_{2} \mathrm{O}_{5}$ is also high $(>0.4 \mathrm{wt} \%)$ and consistent with the high- $\mathrm{K}$ character. About half of the mafic-intermediate rocks have rather low $\mathrm{MgO}(2-5 \%)$ and high $\mathrm{Fe}_{2} \mathrm{O}_{3 \text { total }}$ 
(>10 wt $\%$ ) and consequently are ferroan on $\mathrm{FeO} /(\mathrm{FeO}+\mathrm{MgO})$ versus $\mathrm{SiO}_{2}$ diagram (Miyashiro, 1974). The basalts have high $\mathrm{TiO}_{2}(1.5-2 \%)$ as compared to typical basalts from subduction zones, but they have rather high $\mathrm{Al}_{2} \mathrm{O}_{3}(>18 \%)$, which is typical of subduction-related lavas. The trachyandesites have high $\mathrm{Na}$, $\mathrm{K}$, and $\mathrm{P}$ compared to the trachybasalts in this sequence. On primitive mantle normalized trace element diagrams (Fig. 12), the trachybasalts lack strong negative Ti-anomalies so typical of subduction zone magmas, but they have negative $\mathrm{Nb}$ anomalies and positive $\mathrm{Pb}$ and $\mathrm{Sr}$ anomalies. The Ti-Zr-Y concentrations of the basalts fall in the range of volcanic arc basalts and the more evolved trachyandesites lie on the border between the arc and within plate basalt fields (Fig. 13; Pearce and Cann, 1973). But their relatively low $\mathrm{Nb}$ concentrations and negative $\mathrm{Nb}$ anomalies make them more similar to volcanic arc basalts. $\mathrm{Sr}$ declines regularly with silica indicating the plagioclase remained stable in the mafic to silicic differentiation trends; this accords with the petrography. They are moderately enriched in LREE (Fig. 11) and other large ion lithophile elements, but this could be the result of alteration.

Ferrari et al. (2014) showed that igneous rocks 93-70 Ma in western Mexico are virtually restricted to the Jalisco block; they relate the magmatism to subduction of the Farallon plate to the east beneath Mexico. The Cretaceous igneous suite of the Tecolotlan graben very similar to other Cretaceous to Paleogene magmatic rocks of Jalisco as compiled by Ferrari et al. (2014). They are notably different than a Cretaceous to Paleocene suite of adakitic rocks found to the SE. They have deeper $\mathrm{Nb}$ anomalies, lower concentrations of LREE and Y, positive Sr anomalies (even in the felsic rocks), and significantly higher $\mathrm{Sr} / \mathrm{Y}$ and La/Y ratios. Ferrari et al. (2014) interpret these distinctive magmas to have formed when a tear and slab window developed and the basaltic/ eclogitic oceanic crust partially melted.

In short, the Cretaceous igneous rocks show many of the mineralogical and geochemical features of subduction-related continental margin volcanic rocks - the trace element patterns of the mafic rocks, a wide range of compositions, predominance of rhyolite, high LILE/HFSE (high field strength elements) ratios, along with quartz and biotite in the more felsic rocks. However, some of the mafic lavas have high $\mathrm{Fe} / \mathrm{Mg}$ ratios and high $\mathrm{TiO}_{2}$ concentrations and a few of the felsic rocks have within plate characteristics with high $\mathrm{Y}$ and $\mathrm{Nb}$. Thus, the environment seems to have been in a continental arc that was experiencing extension-much like the modern Trans-Mexican volcanic belt. We conclude that the Cretaceous igneous rocks were not formed in an island arc that became accreted to North America. Instead, the compositions are more consistent with an arc that was built on already established continental crust.

\section{Neogene and Quaternary Units}

\section{Formation of San Jose (Late Hemphillian-Tsj)}

Within the Tecolotlan graben, Hemphillian age (North American Land Mammal age, Wood et al., 1941), poorly con- solidated sedimentary rocks unconformably overlie the Late Cretaceous rocks (Plate 1 and Fig. 14). These rocks (herein informally called the formation of San Jose because of the good exposures along the Arroyo San Jose and near the village of San Jose (Plate 1), are the oldest sedimentary fill associated with the onset of extension.

The formation of San Jose is comprised mostly of fine siltstones and mudstones, alternating in color from light gray green to light reddish brown with a minimum thickness of 30-35 m (Fig. 14). Some white caliche horizons occur, usually within the light gray green mudstones; these may be quite laterally extensive. Coarse detritus is rare in the formation, but a few fluvial sandstone and conglomerate layers are present, usually within the reddish brown siltstones and mudstones. The sandstones are litharenites (classification of Folk, 1974), with quartz + feldspar generally less than $\sim 20 \%$ (Fig. 8). The formation appears to be mostly fluvial and overbank deposits, except near the middle of the formation where thinly bedded, carbonate cemented sands and interbedded mudstones were probably deposited in a small lake (Fig. 10D). The lacustrine beds are only a small part of the total section and may have been deposited when lava flows dammed the drainage at the southern end of the map area.

Age control for the formation of San Jose comes from interbedded volcanic rocks and from fossils. A trachyandesite lava flow (Tables 1 and 2, Tm sample JT-K119), has been dated at $4.95 \pm 0.02 \mathrm{Ma}$. A rhyolite ash fall bed (Fig. 10E), in places up to $0.5 \mathrm{~m}$ thick, at about the same stratigraphic level as the trachyandesite flow was previously dated at $4.95 \pm 0.16$ Ma (Table 1; JT-K18; recalculated age from original publication of Kowallis et al., 1998 with new FCT age standards). The youngest mafic lava flow (JT-D), with a ${ }^{40} \mathrm{Ar} /{ }^{\beta 9} \mathrm{Ar}$ age of $3.59 \pm 0.01 \mathrm{Ma}$, is near Los Duendes, $\sim 4 \mathrm{~km}$ northeast of Tecolotlan (Plate 1). It sits atop the formation of San Jose and fills a small valley with little or no topographic inversion. The age of the formation of San Jose, based on mammal fossils, is latest Hemphillian to possibly earliest Blancan. The age of the Hemphillian-Blancan boundary is between 4.7 and 4.8 Ma (Flynn et al., 2005); the radiometric ages confirm this age assignment. The formation has produced a wide variety of excellently preserved vertebrate fossils. Included are horse, mastodon, camel, rhinoceros, crocodile, turtle, capybara, sloth, etc. Some of these fossils have been described (Miller and Carranza-Castañeda, 1998c; Carranza-Castañeda and Miller, 2002; Carranza-Castañeda and Miller, 2004; Lucas, 2008; Carbot-Chanona et al., 2009) while others are still being studied. Key index fossils found in these sediments include: Dinohippus mexicanus, Neohipparion eurystyle, Teleoceras fossiger, Canis ferox, and Notolagus velox.

A significant unconformity (Fig. 10C) occurs at the top of these beds. This period of erosion likely removed some of the Blancan age sediments, which were deposited in the graben. Based upon the isotopic data from this formation, its age appears to range between ca. $5 \mathrm{Ma}$ and 3.6 Ma being deposited during active rifting of the graben. 

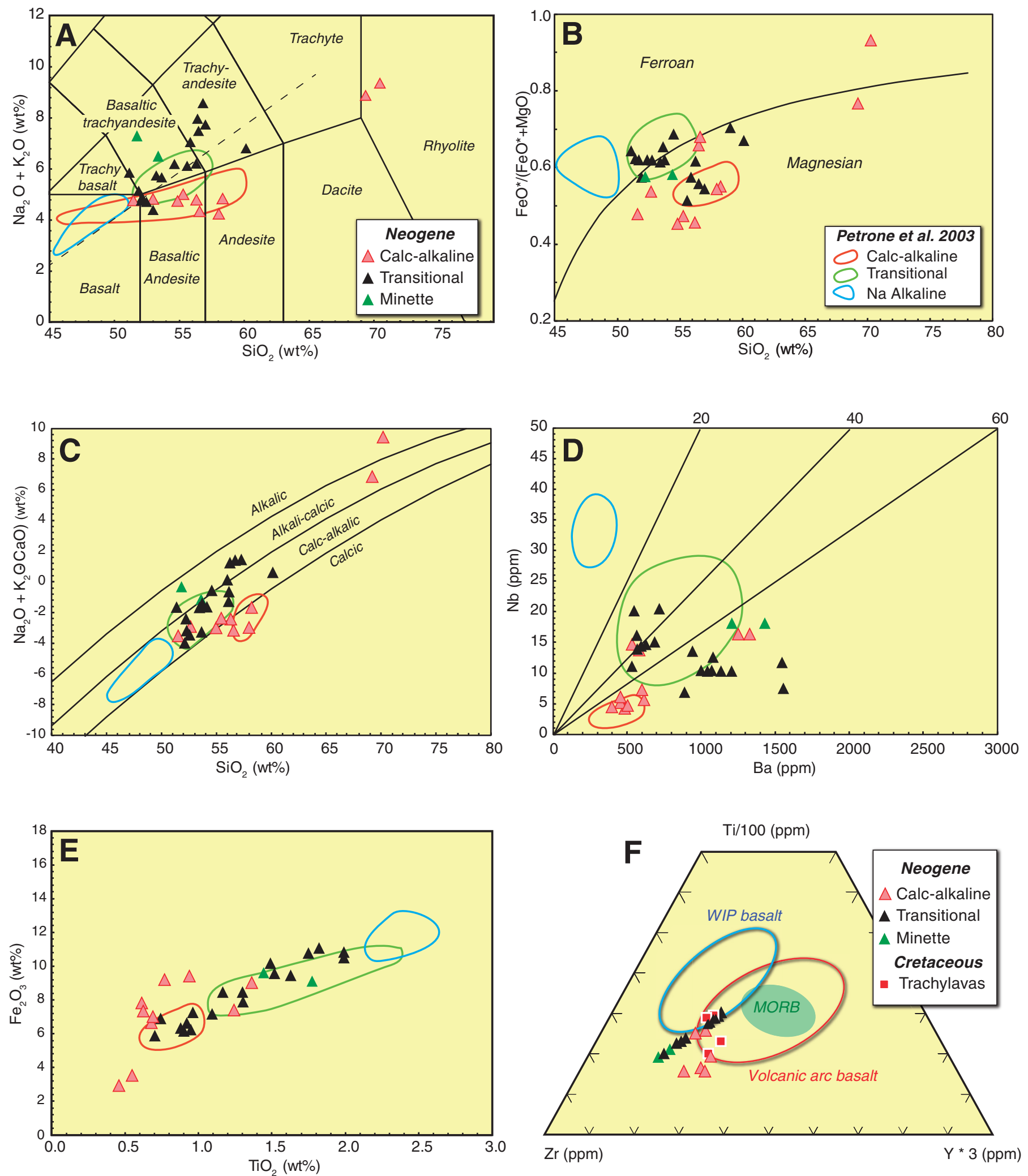

Figure 13. Geochemistry of the Neogene volcanic rocks from Tecolotlan compared with the volcanic series identified by Petrone et al. (2003). (A) Total alkali-silica diagram. (B) Ferroan and magnesian series using the discriminant of Miyashiro (1974). (C) Modified alkali-lime index (Frost et al., 2001). (D) Nb-Ba diagram. Most mafic to intermediate arc magmas have $\mathrm{Ba} / \mathrm{Nb}$ ratios over 40 . (E) $\mathrm{TiO}_{2}-\mathrm{Fe}_{2} \mathrm{O}_{3}$ showing that the minettes and transitional series typically have higher $\mathrm{TiO}_{2}$ for a given $\mathrm{Fe}_{2} \mathrm{O}_{3}$ concentration. (F) $\mathrm{Zr}$-Ti-Y ternary for mafic rocks with the $10 \%$ probability ellipses of Pearce (1996). Taken as a whole, the Neogene volcanic rocks are most similar to volcanic arc basalts. The compositions that fall out of the ellipse are dominantly more evolved than basalt. The Cretaceous mafic lavas plot in a similar part of the diagram, consistent with an arc affiliation. 


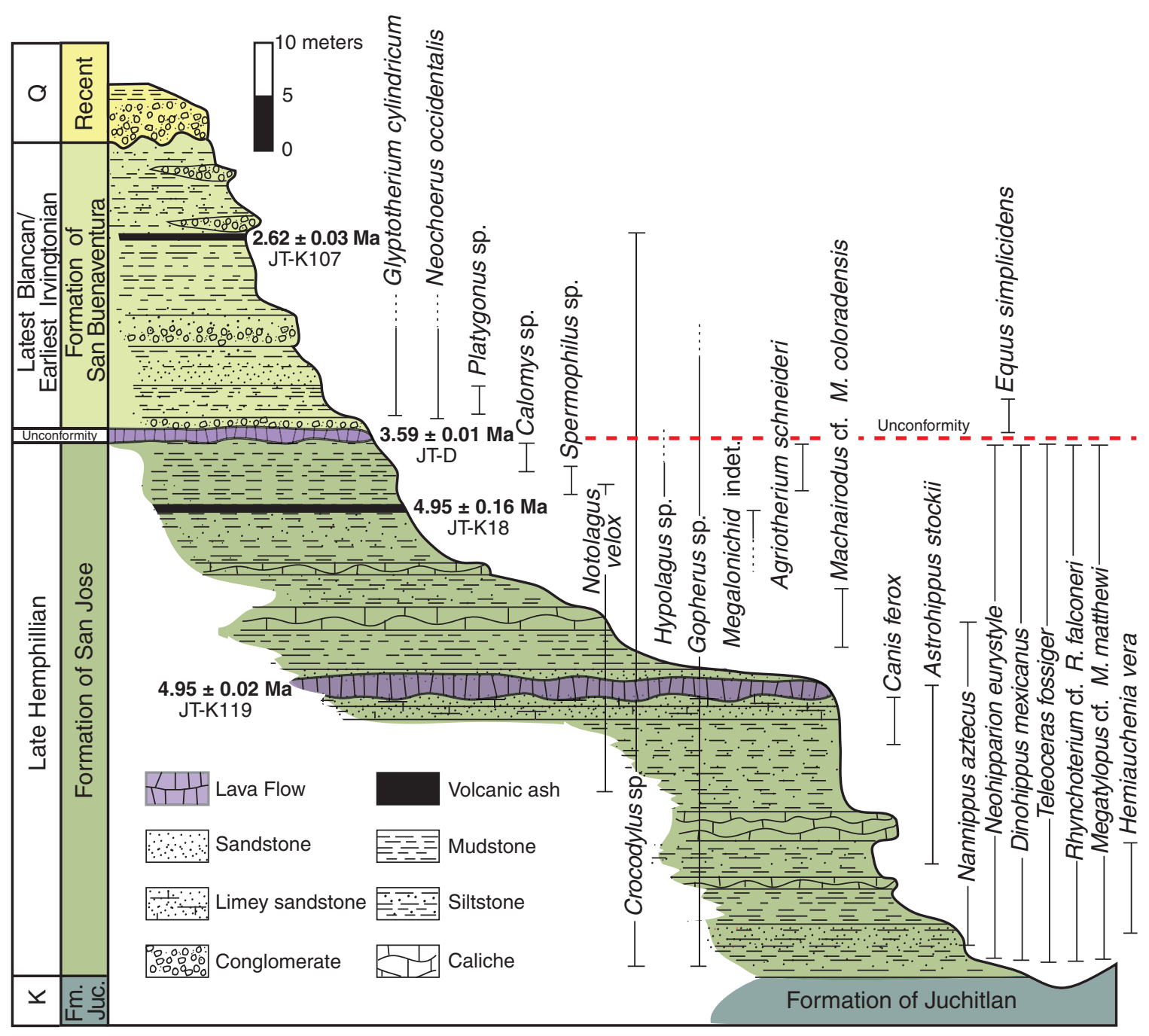

Figure 14. Composite biostratigraphic section of the San Jose beds (Late Hemphillian) and the Tecolotlan beds (latest Blancan/earliest Irvingtonian) in the Tecolotlan valley, Jalisco, Mexico. The stratigraphic ranges of fossil mammals found in these beds and the ages of a few key dated horizons are also shown.

\section{Formation of San Buenaventura (Late Blancan to Early Irvingtonian-QTsb)}

Sediments of Late Blancan to Early Irvingtonian age have been mapped as the formation of San Buenaventura (Plate 1). This unit is deposited unconformably on the Early BlancanHemphillian age formation of San Jose suggesting a period of erosion removed middle Blancan age sediments, which may have been deposited in the graben. It consists of generally coarse-grained poorly consolidated sediment. The thickness of the formation of San Buenaventura is quite variable. In some places it is over $30 \mathrm{~m}$ thick and in other places only a meter or two thick. At the base of the unit, poorly bedded gravels, sands, and mudstones, grade upwards into discontinuous small channels $(<1 \mathrm{~m}$ deep) filled with gravel that are cut into finer grained siltstone and sandstone (Fig. 10C and Plate 1). Based on this, we conclude that the unit was deposited in a fluvial environment with higher overall energy than the older formation of San Jose, probably in braided streams flowing across alluvial fans. The contact with the underlying formation of San Jose is an irregular surface and shows that either considerable topography existed within the basin at the time these deposits were laid down, or that there have been repeated periods of downcutting, stabilization of the topography with deposition of sediment, and then renewed downcutting. A pyroclastic fall tuff in these sediments has an age of $2.62 \pm 0.03 \mathrm{Ma}$ (JT-K107, Table 1 and Fig. 4), consistent with a Late Blancan age for the older part of the unit. This Late Blancan age is further substantiated by the presence of the horse Nannippus peninsulatus, which is only known from rocks of this age.

In addition to the horse fossil, other vertebrate fossils found in these sediments include teleost fish, lizard, turtle, tortoise, crocodile, camel, peccary capybara, mastodont, and glyptodont. 


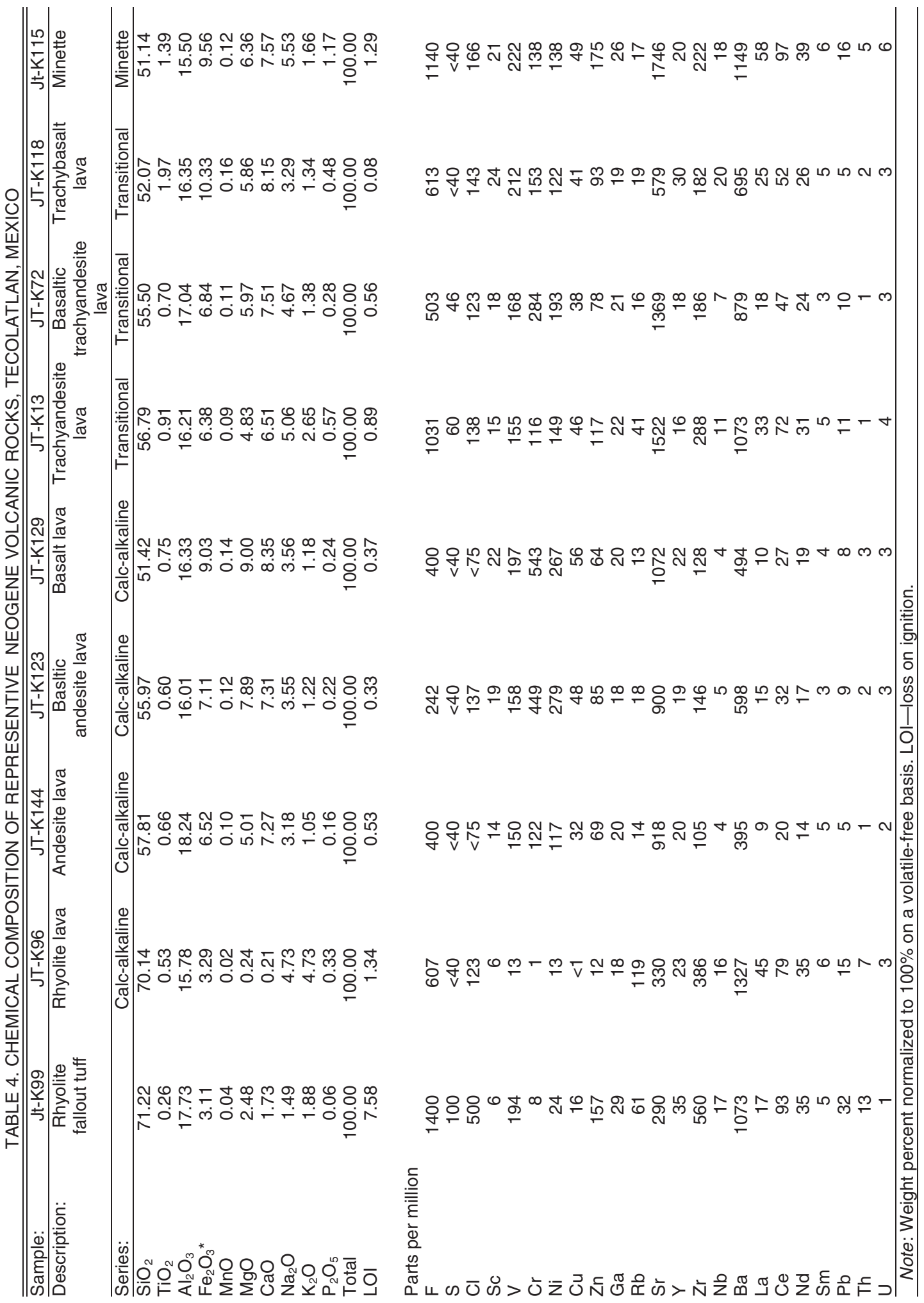


Vertebrate fossils, in general, are not as common as in the underlying formation of San Jose.

\section{Alluvium and Colluvium (Qac)}

This unit consists of colluvium and alluvium found on generally flat surfaces, but at a higher elevation than Quaternary alluvium (Qa). It is typically composed of unconsolidated sand and gravel and has thicknesses of $0.5 \mathrm{~m}$ to perhaps as much as $10 \mathrm{~m}$. This material has been deposited post-rifting and suggests periods of renewed downcutting of the valley, perhaps related to changes in base level.

\section{Colluvium (Qc)}

This unit is composed of unconsolidated sand and gravel deposited on slopes.

\section{Mass Movement Deposits (Qms)}

Small landslide or mass movement deposits formed in the southern part of the map near the town of Juchitlan on the flanks of a small volcano, which lies mostly to the south of the map area on Plate 1, where erosion along the drainage has destabilized the slope. The largest is $\sim 0.5 \mathrm{~km}$ across.

\section{Recent Alluvium (Qa)}

Recent alluvium consists of unconsolidated sand and gravel deposited in modern drainages. Currently, the older valley fill of the formations of San Jose and San Buenaventura, along with the higher level alluvium and colluvium are being dissected and eroded with the modern basin drainage mostly to the south through Arroyo Tamazula (Plate 1). Within the major arroyos, thin $(<5 \mathrm{~m})$ deposits of unconsolidated sand and gravel comprise the youngest sedimentary deposits in the mapped area.

\section{NEOGENE VOLCANIC ROCKS}

A variety of Pliocene volcanic units occur in and near the Tecolotlan graben. The Cenozoic volcanic rocks are generally less altered than the Cretaceous volcanic rocks (Fig. 13 and Table 4). The lava flows are correlative with the Chapala Group basalts and andesites mapped by Ferrari et al. (2000) just to the north and east of the study area and form the volcanic front of the Late Pliocene to Quaternary episode of Ferrari et al. (2012). They are dominated by small lava flows and cinder cones that erupted from central vents in and near the graben. However, the lavas did not erupt to form a single central volcano as they have in much of the Trans Mexican volcanic belt. Several of the mafic and silicic flows appear to have erupted from vents close to the graben-bounding faults. A thick stack of these lavas lies on the southern border of the map. Capping the top of the western footwall escarpment (at Cerro la Coronilla) are several andesite flows (JT-34) that have filled an old channel cut down through the older Cretaceous volcanic and clastic rocks below (Fig. 6B). The flows are $\sim 15 \mathrm{~m}$ thick in the center of the old channel. Another small flow of trachyandesite and trachybasalt (JT-K72 and 73), which has been partially down-faulted along the western margin of the graben, is located just to the west of the city of Juchitlan. It has an age of $4.76 \pm 0.02 \mathrm{Ma}$ (Table 1 and Fig. 3 ).

We have subdivided the volcanic sequence into a calcalkaline and a transitional suite, following the nomenclature of Petrone et al. (2003) for volcanic rocks in the nearby TepicZacoalco graben. The volcanic rocks are divided into four types on Figure 15: calc-alkaline basalt to andesite lavas and scoria, calc-alkaline rhyolite lava, transitional trachylavas, and minette lava flows. Two distal fallout tuff beds are also discussed here.

\section{Pliocene Calc-alkaline Suite}

The calc-alkaline suite includes basalt, basaltic andesite, and andesite lavas (Figs. 12 and 13). Beds of dark colored volcanic sediment (sand to gravel size) and cinders (unit Tms), which are variably inclined $20-55^{\circ}$ to the east, outcrop east of Los Corrales where they are $30+\mathrm{m}$ thick and interpreted to be the remnants

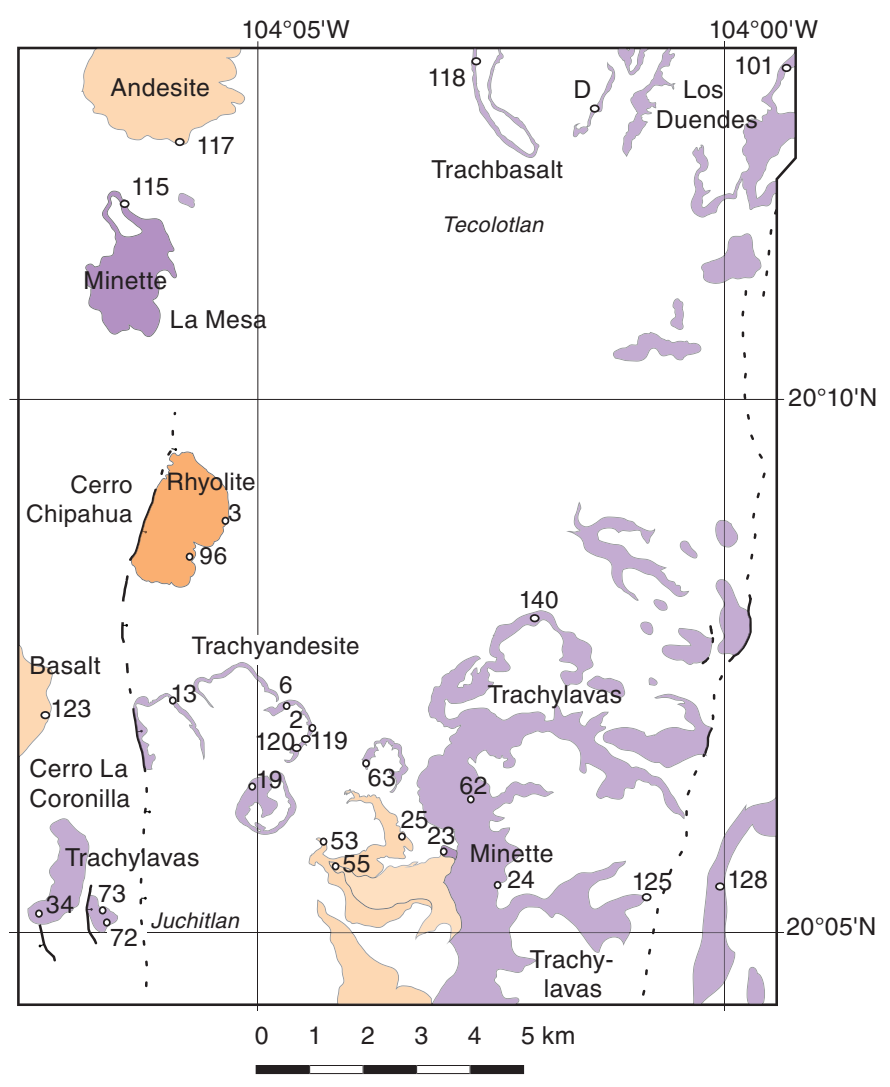

Pliocene Volcanic Rocks

$\square$ Calc-alkaline basalt, basaltic andesite, and andesite $\square$ Calc-alkaline rhyolite

$\square$ Transitional trachybasalt, basaltic trachyandesite, and trachyandesite $\square$ Transitional minette

Figure 15. Map of Neogene volcanic rock outcrops subdivided by chemical composition. 
Kowallis et al.

of a buried basaltic andesite cinder cone that is currently being dissected and eroded along a steep arroyo. Dacite is absent, but the Cerro Chipahua rhyolite ( $\mathrm{Tr}$ ) formed a grayish red flow-dome complex on the western margin of the graben (Plate 1 and Fig. 10A). The rhyolite has previously been mapped as an intrusive diorite pluton (Vasquez-Tortoledo et al., 2011), but thin section, field evidence, and compositional data show it to be an accumulation of rhyolite lavas. The lavas consist of a fine-grained matrix with phenocrysts of quartz, sanidine, plagioclase, biotite and Fe-Ti oxides. None of the lavas of the calc-alkaline suite have been radiometrically dated, but based on stratigraphic relations they must be between 4 and 5 Ma (Plate 1).

The mafic and intermediate calc-alkaline rocks typically have plagioclase as the main phenocryst phase, accompanied by olivine and clinopyroxene. The rhyolite dome has phenocrysts of quartz, plagioclase, sanidine, and hornblende.

The calc-alkaline series forms a nearly continuous trend on most variation diagrams (Figs. 13 and 16). The lavas are distinctly magnesian using the Miyashiro (1974) criterion on $\mathrm{a} \mathrm{SiO}_{2}$ versus $\mathrm{FeO} / \mathrm{MgO}$ diagram. They are medium $\mathrm{K}_{2} \mathrm{O}$ and calcic to calc-alkaline rocks comparable in most ways to the "calc-alkaline" suite identified by Ferrari et al. (2001) and Petrone et al. (2003) in this region and similar to volcanic rocks found in arc settings worldwide. The most mafic members of the suite also have distinctly lower $\mathrm{TiO}_{2}$ than the more alkaline rocks described below and are thus typical of volcanic arc basalts $\left(\mathrm{TiO}_{2}<1.2 \%\right.$; Gill, 1981). Zr-Ti-Y systematics of these rocks are also consistent with their classification as part of a subduction-related calc-alkaline suite (Fig. 13; Pearce and Norry, 1979; Pearce and Cann, 1973; Pearce, 1982). The calc-alkaline basalts and basaltic andesites range from 9 to $7 \% \mathrm{MgO}$ and are fairly primitive with high concentrations of $\mathrm{Cr}(400-600 \mathrm{ppm})$ and $\mathrm{Ni}(250-300)$ as well (Table 4; Fig. 16). They can be distinguished from the transitional series by their lower $\mathrm{TiO}_{2}(<1.2 \%), \mathrm{P}_{2} \mathrm{O}_{5}, \mathrm{Rb}, \mathrm{La}, \mathrm{Ce}, \mathrm{Y}$, $\mathrm{Zr}, \mathrm{Nb}, \mathrm{Ba}$ and higher $\mathrm{MgO}, \mathrm{Cr}, \mathrm{Ni}, \mathrm{Cu}, \mathrm{Sr}, \mathrm{Pb}$ at a given silica content (Figs. 13 and 16; Table 4). The Cerro Chipahua dome is a low-silica rhyolite $\left(\sim 70 \% \mathrm{SiO}_{2}\right)$ with rather high $\mathrm{Zr}, \mathrm{Ba}$, and $\mathrm{Sr}$, attesting to its unevolved nature.

Normalized trace element patterns of members of the calcalkaline series (Fig. 17) display deep $\mathrm{Nb}$ and $\mathrm{Ti}$ anomalies, coupled with strong enrichments of $\mathrm{Ba}, \mathrm{U}, \mathrm{K}, \mathrm{Pb}$, and $\mathrm{Sr}$-elements considered to be soluble in subduction zone fluids (or enriched in subducted sediment). $\mathrm{P}$ is flat to negative, indicative of apatite fractionation, and in contrast to the trace element patterns for the transitional suite described below. The magnesian character (Fig. 13 ) of the calc-alkaline rocks indicates high magmatic $\mathrm{fO}_{2}$, also consistent with subduction zone processes.

The calc-alkaline lavas form a broadly bimodal association of rhyolite and the basalt to andesite suite with no dacite to span the gap. However, the rhyolite lava flow has a trace element composition more akin to those generated in volcanic arcs than with bimodal volcanic suites associated with extension in the Basin and Range province of North America. For example, the rhyolite lava is not particularly enriched in incompatible trace elements, is enriched in LILE, and has a strong negative $\mathrm{Nb}$-anomaly on trace element diagrams (Fig. 17) and plots with volcanic arc granites on the discrimination diagram of Pearce et al. (1984).

\section{Pliocene Transitional Suite}

In contrast to the calc-alkaline rocks, a distinctive group of minette, trachybasalt, basaltic trachyandesite, and trachyandesite lavas erupted in and on the flanks of the Tecolotlan graben. We call this the transitional suite in accord with the nomenclature of Petrone et al. (2003).

The trachylavas (included in unit Tm of Plate 1; Fig. 13) are either intercalated with or cap the formation of San Jose. Within the graben, transitional flows are interbedded with the formation in the southern half of the mapped area (trachyandesite JT-K119 is $4.95 \pm 0.02 \mathrm{Ma}$ from a road cut along Highway 80) as well as to the northeast of the mapped area (basaltic trachyandesite JT-K101b with an age of $4.67 \pm 0.1 \mathrm{Ma}$ also from a road cut along Highway 80 in the northeastern most part of the map area). The youngest mafic flow (basalt JT-D dated at $3.59 \pm 0.01 \mathrm{Ma}$ ) is $\sim 4 \mathrm{~km}$ northeast of Tecolotlan. It fills a small valley with no evidence of significant topographic inversion. Minette lavas (unit Tm) have been found in two places (Plate 1 and Fig. 15). The 4.95 Ma La Mesa minette (JT-K115) caps a mesa on the western footwall of the graben and another is exposed with the trachybasalts in the flows that blocked the south end of the valley.

In the field, the transitional lavas can be distinguished from the calc-alkaline rocks by the general absence of plagioclase phenocrysts. Instead, olivine or olivine-clinopyroxene assemblages are dominant; a few trachyandesite flows also have amphibole phenocrysts. These phenocrysts are contained in a groundmass of flow-aligned plagioclase, augite, and Fe-Ti oxides. The minette lavas have phenocrysts of olivine, clinopyroxene, and phlogopite and what appear to be blebs of magmatic carbonate. Righter and Rosas-Elguera (2001) identified similar minette lavas of the same age in the nearby Ayutla volcanic field. The lack of plagioclase phenocrysts in the transitional series is probably the result of high pressure crystallization (Petrone and Ferrari, 2008) or high water contents $\left(3 \%-5 \% \mathrm{H}_{2} \mathrm{O}\right)$ as found by Moore and Carmichael (1998), Righter and Carmichael (1996), and Blatter and Carmichael (1998) for lavas near the volcanic front in Jalisco and in central Mexico.

The lavas of the transitional series have higher alkalies and $\mathrm{FeO} /(\mathrm{FeO}+\mathrm{MgO})$ ratios (Fig. 13) than the contemporaneous calc-alkaline series. In spite of their high alkali contents, all but the minettes and one trachyandesite are silica-saturated. The trachylavas have prominent negative $\mathrm{Nb}$ and $\mathrm{Ti}$ anomalies and positive $\mathrm{Pb}$ and $\mathrm{Sr}$ anomalies on normalized trace element diagrams (Fig. 17), indicating a link to subduction processes; in this way, they are unlike the Na-alkaline series of Petrone et al. (2003). Chemically, the trachylavas are distinguished from the contemporaneous calc-alkaline suite by lower $\mathrm{MgO}, \mathrm{Ni}$, and $\mathrm{Cr}$, and higher concentrations of $\mathrm{Ba}, \mathrm{Sr}$, LREE, $\mathrm{Zr}, \mathrm{Nb}$, $\mathrm{Ti}_{2} \mathrm{O}, \mathrm{K}_{2} \mathrm{O}$, and $\mathrm{P}_{2} \mathrm{O}_{5}$ at similar silica contents (Figs. 13 and 16). 

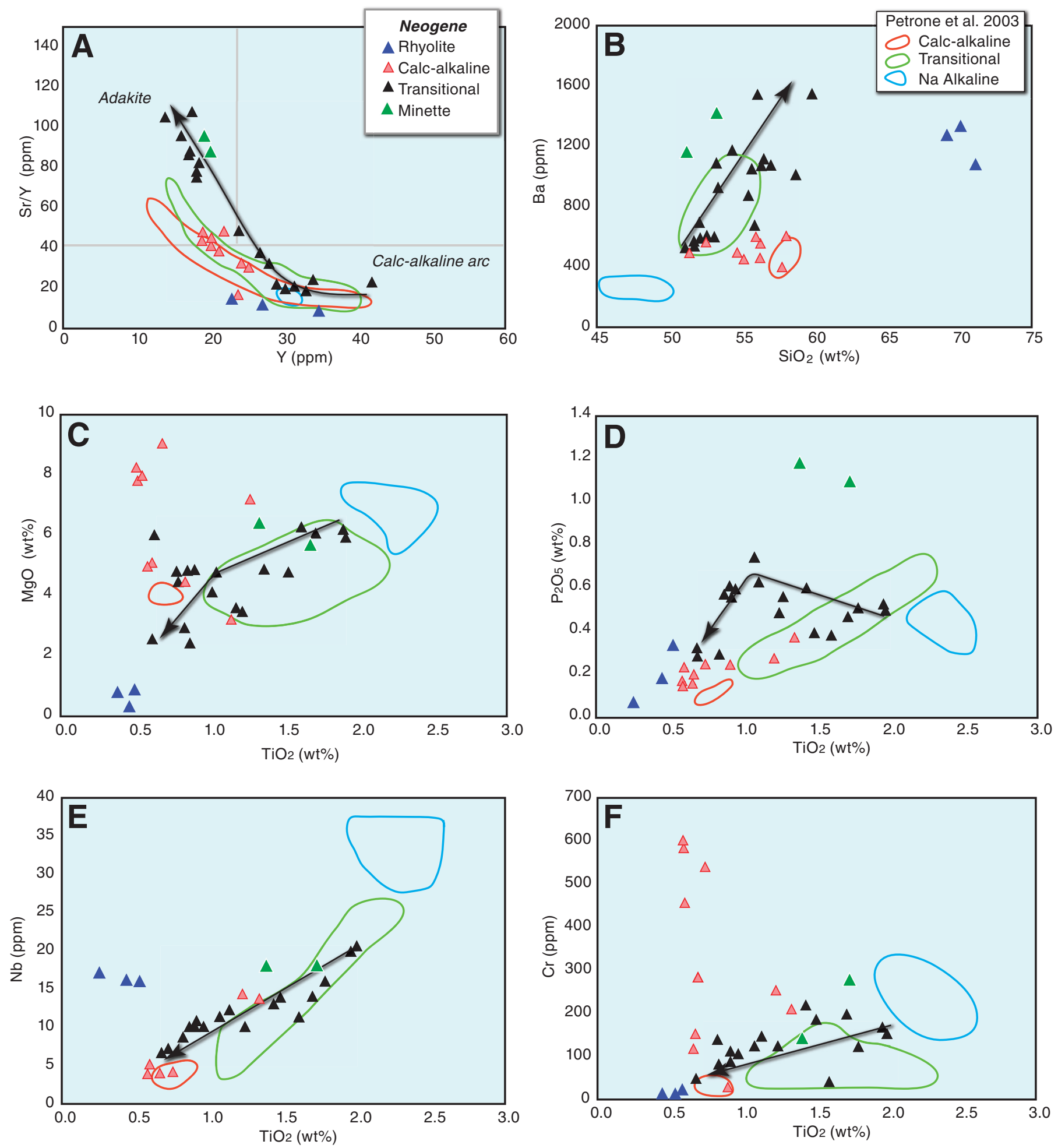

Figure 16. Variation diagrams contrasting the compositions of the Pliocene minettes, transitional series, and calc-alkaline series of the Tecolotlan graben. The black arrows show the differentiation trends in the transitional series. The fields for the Na-alkaline, transitional, and calc-alkaline series of Petrone et al. (2003) are shown for comparison. No members of the Na-alkaline series erupted near Tecolotlan, but members of the transitional and calc-alkaline series are common. 

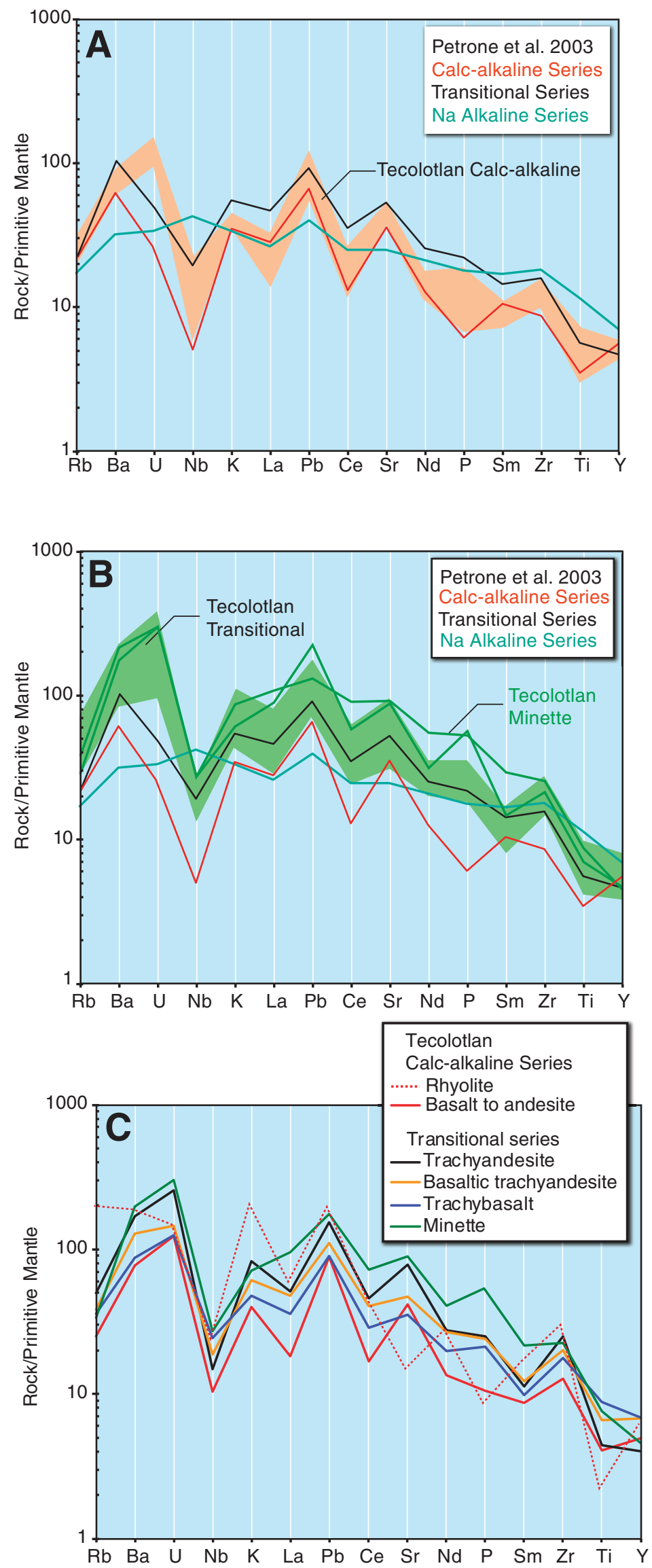

Figure 17. Incompatible element patterns for igneous rocks from the Tecolotlan graben. Representative members of the Naalkaline, transitional, and calc-alkaline series of Petrone et al. (2003) are shown for comparison. The calc-alkaline and transitional series are similar to those in the western part of the TransMexican volcanic belt, but no members of the Na-alkaline series erupted in the Tecolotlan graben. Fields are shown for the Tecolotlan data in (A) and (B); the average pattern for each rock-type is shown in (C). Normalization values for primitive mantle are from Sun and McDonough (1989). 
$\mathrm{P}_{2} \mathrm{O}_{5}$ ranges from 0.3 to $0.7 \%$ and exceeds $1 \%$ in the minettes (Fig. 16). With increasing silica content, $\mathrm{Sr}$ increases reaching $1800 \mathrm{ppm}$ in the most evolved trachyandesites (Figs. 16 and 17). In contrast, $\mathrm{Sr}$ declines with evolution in the calc-alkaline series. Y also displays anomalous behavior in the trachylavas; $\mathrm{Y}$ concentrations decline from 35 to $15 \mathrm{ppm}$ as silica or other measures of differentiation increase (Table 4). Differentiation at high pressure where plagioclase (in which $\mathrm{Sr}$ is compatible) was unstable and garnet and amphibole (in which $\mathrm{Y}$ is compatible) were stable explains these geochemical characteristics. Petrone and Ferrari (2008) also discussed the role of high pressure crystallization for more silicic volcanic rocks in the Tepic-Zacoalco graben. The combined increase in $\mathrm{Sr}$ and decrease in $\mathrm{Y}$ concentrations with differentiation leads to high $\mathrm{Sr} / \mathrm{Y}$ ratios (Fig. 16) in the trachyandesites that are similar to those in adakites (Drummond et al., 1996), but which we interpret to be the result of differentiation at high pressure.

In general, this suite of lava flows is most similar to the "transitional series" of Ferrari et al. (2001) and Petrone et al. (2003) in the Tepic-Zacoalco graben north of Tecolotlan. There, they are transitional between a calc-alkaline suite and a Na-alkaline suite of lavas with characteristics of ocean island basalts (Figs. 13 and 16; Ferrari et al., 2001); these Na-alkaline lavas did not erupt in the Tecolotlan graben; apparently rifting was not advanced far enough to produce this sort of alkaline, silica-undersaturated, Nb-Ti rich magma. Righter and Rosas-Elguera (2001) include some of these transitional lavas on the Jalisco block in an "intraplate alkaline series," but they are unlike the Na-alkaline series with distinctly lower $\mathrm{Nb}$ and $\mathrm{TiO}_{2}$ concentrations and have many characteristics suggesting a relationship to plate-margin processes. The lavas in the transitional series are similar to what Carmichael et al. (1996) called absarokites, shoshonites, and latites, but because they are not typically potassic $\left(\mathrm{K}_{2} \mathrm{O}<\mathrm{Na}_{2} \mathrm{O}-2\right)$, we use the more general terms trachybasalt, basaltic trachyandesite, and trachyte (Fig. 13). The Tecolotlan transitional series is not as extreme as the lavas at Mascota and Ayutla (Righter and RosasElguera, 2001) with higher $\mathrm{Al}_{2} \mathrm{O}_{3}$ and lower $\mathrm{Ba}, \mathrm{Sr}, \mathrm{Fe}_{2} \mathrm{O}_{3}, \mathrm{MgO}$, and $\mathrm{K}_{2} \mathrm{O}$.

The minettes share chemical similarities with other members of the transitional series but they are more enriched in most incompatible trace elements (Figs. 13, 16, and 17). For example, they have the highest concentrations of $\mathrm{P}_{2} \mathrm{O}_{5}, \mathrm{Nb}, \mathrm{Sr}, \mathrm{Ba}$, LREE, $\mathrm{Zn}, \mathrm{Pb}$, and $\mathrm{U}$ of the rocks erupted here (Table 4). However, they are not as enriched in high field strength elements (e.g., Ti, Zr, and $\mathrm{Nb}$ ) as the Na-alkaline series found in the adjacent grabens and they have deep negative $\mathrm{Nb}$ anomalies (Fig. 17). The minettes generally have $\mathrm{MgO}, \mathrm{Ni}, \mathrm{Cr}$ concentrations comparable to other members of the transitional series, and considerably lower than in the mafic calc-alkaline rocks found in the Tecolotlan area (Fig. 16). They lie on slightly different chemical trends than the trachylavas and must have an independent origin.

Phlogopite and the typical absence of plagioclase phenocrysts in the minettes must reflect relatively high concentrations of water in the magmas, which suppressed the crystallization of plagioclase. Experiments suggest 3.5-6\% water in the minette melts (Carmichael et al., 1996). Carmichael et al. (1996) interprets their composition to mean that phlogopite, apatite, zircon, spinel, garnet, and sulfides were present in veins in a lithospheric mantle source and contributed in varying proportions to minette melts that grade into the trachylavas. Similarly, Vigouroux et al. (2008) concluded that minettes formed by partial melting of mantle veined with clinopyroxene, phlogopite, garnet and that apatite was consumed by melting. The presence of garnet in the source requires pressures greater than $25 \mathrm{~kb}$ within the mantle wedge rather than the lithosphere.

The chemical composition of minettes from Tecolotlan fall within the range for other minettes in the Jalisco block, but they are richer in $\mathrm{Na}_{2} \mathrm{O}$ and lie on the less incompatible trace element enriched end of the spectrum reported by others. Minette lavas are rare in the volcanic record elsewhere, but here they are commonly found in a NW-trend along the front of the Trans Mexican volcanic belt (Fig. 1) including San Sebastian (Lange and Carmichael, 1990), Mascota (Carmichael et al., 1996; Maria and Luhr, 2008), Los Volcanes (Wallace and Carmichael, 1992), Tapalpa (Righter and Rosas-Elguera, 2001), and north of Volcan Colima (Maria and Luhr, 2008; Luhr et al., 1989; Crummy et al., 2014). They form a lineament parallel to the trench and to the TepicZacoalco graben (Fig. 1) and are younger than ca. 4.5 Ma.

\section{Pyroclastic Fall Tuffs}

Two thin beds of fallout tuff are interlayered with the basinfill sediments and do not have local eruption sources. One rather altered fallout tuff (JT-K99) in the formation of San Jose has high $\mathrm{Al}_{2} \mathrm{O}_{3}, \mathrm{MgO}$, and LOI values (Table 4) that are the result of secondary alteration, but immobile element ratios suggest that it was originally rhyolitic (Fig. 11). Its high concentrations of Zr, Y, Zn, and $\mathrm{Ga}$ are most likely the result of enrichment during alteration and weathering and probably do not indicate that the tuff was originally peralkaline. Based on the $\mathrm{Al}_{2} \mathrm{O}_{3}$ enrichment of $\sim 1.5$ times, the original $\mathrm{Zr}$ concentration would have been $\sim 360 \mathrm{ppm}$, about the same as the local non-peralkaline lava Tr.

Within the overlying formation of San Buenaventura is another clay altered and $\mathrm{Al}_{2} \mathrm{O}_{3}$-rich fallout tuff (JT-K107), with an age of $2.62 \mathrm{Ma}$ (Table 1 and Fig. 4). It appears to have been originally dacitic based on immobile element concentrations (Fig. 11). Its enrichment in high-field strength elements (Table 3 ; Fig. 12) is also likely due to weathering and alteration. Moreover, both fallout tuffs have large negative $\mathrm{Nb}$ and positive $\mathrm{Pb}$ anomalies on trace element diagrams (not shown) inconsistent with peralkaline compositions.

\section{STRUCTURE}

\section{Cretaceous Tilting or Folding}

The primary focus of our work in the Tecolotlan area was to map, determine ages, and further document the 
Neogene-Quaternary mammal-bearing strata. However, we collected limited structural data from the older rocks in the area. Figure 18 shows bedding orientations in the Cretaceous formations. In general, the beds strike NE-SW and dip 15$25^{\circ} \mathrm{W}$ in the western part of the map, while in the central area they strike either NW-SE or NE-SW $\sim 90^{\circ}$ apart and dip from horizontal to as much as $70^{\circ}$ (Figs. 10F and 18). The few measurements taken in the eastern part of the map area strike NE-SW and dip steeply $55-65^{\circ}$ either to the west or east. The simplest interpretation of the structural data is that the Cretaceous strata are folded. Folding, tilting, and thrusting, have been documented in the Cretaceous rocks of the Guerrero composite terrane elsewhere in southwestern Mexico (e.g., Nieto-
Samaniego et al., 2006; Cerca et al., 2007; Martini et al., 2009; Martini and Ferrari, 2011). Martini et al. (2010) indicate that the Albian age limestones of the Ixtapa Formation of southwestern Mexico have "experienced a moderate phase of shortening, which produced NW-SE-trending upright open folds," while the overlying Coniacian to Maastrichtian volcaniclastic rocks and continental sediments of the La Union Formation "display NW-SE-trending kilometric upright gentle folds." We expect that similar deformation has affected the Cretaceous rocks of the Tecolotlan area with the trends of the folds in this area more to the N-NE, similar to observations by Ferrari et al. (2000). The deformed Cretaceous rocks are overlain unconformably by nearly horizontal sedimentary and volcanic strata
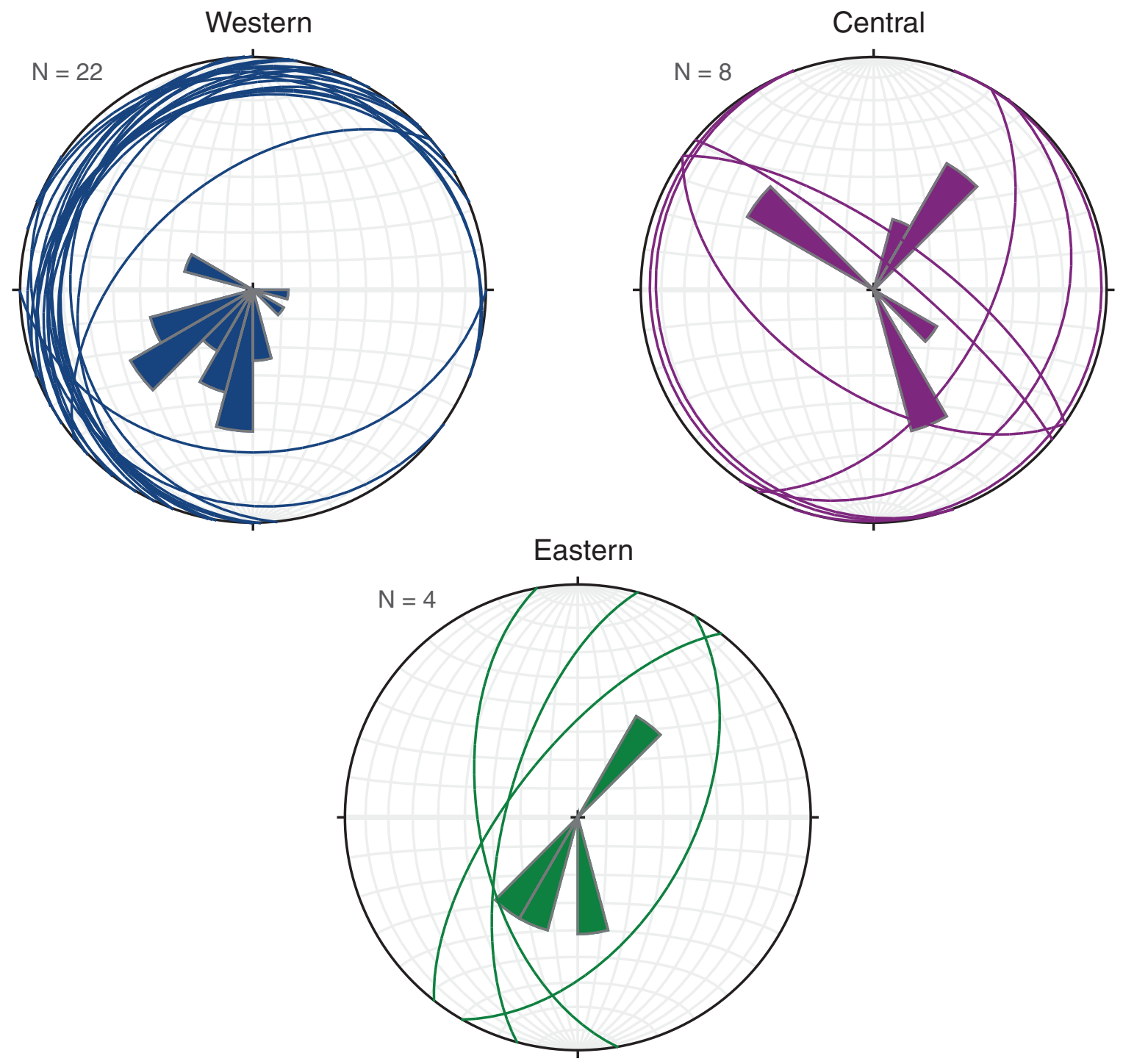

Figure 18. Stereonet diagrams showing the orientation of bedding in the western, central, and eastern parts of the map area. Diagrams produced using the Stereonet program described in Allmendinger et al. (2013) and Cardozo and Allmendinger (2013). 
(Plate 1), implying a distinctive change in tectonic setting after Cretaceous(?) folding.

\section{Neogene Faulting}

Righter and Rosas-Elguera (2001) suggest that this region was unaffected by Neogene extension. This is probably true since ca. $3 \mathrm{Ma}$, but the area experienced a limited amount of extension between ca. 3 and $5 \mathrm{Ma}$, based upon the accumulation of sediment, basin-bounding faults, and dated volcanic rocks as outlined below.

The north-trending basin-bounding faults of the Tecolotlan graben are generally poorly exposed and buried under colluvium, but they are clearly exposed in road cuts that cross them and in a few natural outcrops (Plate 1). All of the observed faults trend more or less NS, approximately parallel to the normal faults bounding the Colima graben (Fig. 1). The total vertical offset on the two major bounding faults is less than $1 \mathrm{~km}$ (perhaps as little as $100-200 \mathrm{~m}$ ) based upon a tentative correlation of some of the Cretaceous tuffs of the Juchitlan beds exposed within the graben to exposures on the western basin-bounding block (Plate 1).

The Neogene and Quaternary sediments and lava flows filling the graben are undeformed with essentially horizontal attitudes and have a maximum thickness of $\sim 100 \mathrm{~m}$. The graben appears to have been dammed at the southeastern end by mafic lava flows-equivalent to JT-K119 in Table 1, which erupted at ca. 4.95 Ma-filling the paleo-drainage and creating a temporary lake in part of the basin during deposition of the formation of San Jose.

The age of extension near Tecolotlan is well constrained by the faunal and radiometric ages of the formation of San Jose, which we interpret to be contemporaneous with rifting. These volcaniclastic rocks have distinctive Early Blancan to Late Hemphillian vertebrate fossils that are older than 3.6 Ma, the age of the youngest lava flow capping them. In addition, the formation of San Jose is interbedded with four dated mafic to intermediate composition lava flows with ages ranging from 4.67 to 4.95 Ma and a fall-out tuff with an age of 4.95 Ma.

Volcanism outside and on the margins of the graben is contemporaneous with sediment fill. One minette lava flow on the western block is $4.90 \mathrm{Ma}$ (JT-K123). A rhyolite lava dome ( $\mathrm{Tr}$, JT-K96) may be contemporaneous with the mafic and intermediate composition lava flows, but its age is unknown and it is cut by the western bounding fault. The non-volcanic formation of San Buenaventura forms a post-rift, basin-filling package that is late Blancan to Irvingtonian in age (younger than $3.6 \mathrm{Ma}$ to perhaps as recent as a few hundred thousand years) based upon fossils. It is interbedded with a distal fallout tuff with an age of $2.62 \mathrm{Ma}$. The basin is currently being uplifted and eroded. Thus, we conclude that extension was active between ca. 5 and 3.6 Ma. Apparently, extension was synchronous with arc volcanism that swept through this area ca. 5-3.6 Ma before becoming established farther north along the Trans Mexican volcanic belt.

\section{GEOLOGIC HISTORY OF THE TECOLOTLAN GRABEN}

\section{Cretaceous History}

In the Jalisco block, the Guerrero terrane consists of late Cretaceous to Eocene granitoids (65-90 Ma) that intruded midto late-Jurassic schists (135-161 Ma) covered by Late Cretaceous to Eocene ignimbrites and lavas (Schaaf et al., 1995; Valencia et al., 2009; Ferrari et al., 2000; Frey et al., 2007; Valencia et al., 2013). The igneous rocks of this terrane have an arc geochemical affinity (Centeno-García et al., 1993; Valencia et al., 2013). It has been proposed that the Guerrero terrane has an oceanic affinity and collided with and accreted onto western Mexico during the Cretaceous (Campa and Ramirez, 1979; Campa and Coney, 1983; Centeno-García et al., 1993; Tardy et al., 1994; Freydier et al., 1997). However, Martini et al. (2009), Martini and Ferrari (2011), and Valencia et al. (2013) concluded that the Guerrero terrane consists mostly of autochthonous or parautochthonous units on the rifted margin of the North American continent. Parts of the Cretaceous batholith have low to negative $\varepsilon N d$ values $(2.4$ to -1.7 ) and Precambrian $\mathrm{Nd}$ model ages also suggesting an older continental basement is present in the Jalisco block (Schaaf et al., 1995; Righter and Rosas-Elguera, 2001).

In the Tecolotlan graben, we find that the model proposed by Martini et al. (2009) and Martini and Ferrari (2011) better explains the chemical and mineralogical nature of the Cretaceous volcanic and sedimentary rocks. During the Late Cretaceous, the area was part of a shallow carbonate shelf as evidenced by deposition of the limestone of Los Guajes. In Chiquilistlán, just east of the Tecolotlan graben, limestones of this age are interbedded with clastic sediment and volcanic rocks from an active volcanic arc (Freydier et al., 1997), but no interbedded volcanic rocks were observed in the Cretaceous limestones of the Tecolotlan area.

Following deposition of the limestone, input from a nearby volcanic arc became important as the sediment record includes thick volcanic debris flow deposits and dacite to rhyolite ash-flow tuffs and mafic to intermediate composition lava flows. During volcanically quite intervals, rivers and streams flowed across the area depositing sand and mud in point bars and overbank fluvial deposits. The Cretaceous felsic rocks, have the geochemical characteristics of a subduction-related suite erupted on a continental margin. The predominance of rhyolite implies the presence of thick felsic crust that allowed the mantle-derived magma to be contaminated and to fractionate in shallow magma chambers. Phenocrystic biotite, rare in arc volcanic sequences, is also consistent with this interpretation. The Cretaceous mafic to intermediate lavas have characteristics intermediate between those of intraplate and arc magmas. They have high $\mathrm{Fe} / \mathrm{Mg}$ ratios and moderately high $\mathrm{TiO}_{2}$ contents (to $2.0 \mathrm{wt} \%$; Table 4), like intraplate suites, but they nonetheless have spikey trace element patterns with negative $\mathrm{Nb}$ and positive $\mathrm{Pb}$ anomalies like subduction-related suites (Fig. 12). The continental sedimentary rocks with which the volcanic rocks are interbedded and the 
abundance of quartz and K-feldspar (Fig. 9) in the clastic rocks support a continental margin to transitional arc setting. These observations and the shelf limestone are all inconsistent with an origin of the basement of this part of the Jalisco block in an oceanic island arc.

The subduction-related magmatic arc continued to be active into the Late Cretaceous and Paleocene (Valencia et al., 2013). Associated with the arc were basins that accumulated sediments and volcanic deposits similar to those describe by Martini and Ferrari (2011) in southwestern Mexico. Intrusion of granodiorite in the northwest part of the area likely occurred during this period (Valencia et al., 2013). The near vent lavas and breccias rocks and the intrusion show that a Cretaceous magmatic arc transected this region. The setting may have been similar to that developed here in the Cenozoic - a continental arc experiencing rifting (to explain the slightly alkaline character of some of the intermediate rocks).

The tilting and folding of these Late Cretaceous rocks were probably part of a broad Late Cretaceous-Early Paleogene shortening event in central and southern Mexico that has been tied to the Laramide orogeny of the North American Cordillera (Campa et al., 1976; Dickinson et al., 1988; Salinas-Prieto et al., 2000; Nieto-Samaniego et al., 2006; Martini and Ferrari, 2011). Accompanying the shortening was regional uplift (Martini and Ferrari, 2011) that created the continental/transitional arc setting for the deposition of the clastic sediments. Martini and Ferrari (2011) have interpreted similar deposits in southwestern Mexico as "infill of a piggyback basin" in the Laramide uplift. This model may similarly apply to the formation of Juchiltan.

\section{Pliocene Rifting and Volcanism}

Between the time that compressional deformation began in the Cretaceous and before $5 \mathrm{Ma}$, the Tecolotlan area was uplifted from near sea level to its current elevation of 1100-1600 m above sea level. The lack of any sedimentary and volcanic deposits with ages between ca. $75 \mathrm{Ma}$ and $5 \mathrm{Ma}$ in the Tecolotlan area suggests a period of erosion and a lack of tectonics that could have produced basins where sediment could have been trapped and preserved. According to Righter et al. (2010) significant Cenozoic uplift and river incision of the Jalisco block were caused by the onset of subduction tectonics beneath the region. No rocks of Eocene to Late Miocene age are exposed in or near the Tecolotlan graben, but volcanism occurred persistently to the north along a subduction-related arc between ca. $75 \mathrm{Ma}$ and $35 \mathrm{Ma}$ with a significant change in character at ca. $56 \mathrm{Ma}$ from wet, oxidized adakitic magmas to dryer and more reduced magmas (Ferrari et al., 2014). Peaks in magmatic activity occurred at ca. $45 \mathrm{Ma}$, $32 \mathrm{Ma}$, and $25 \mathrm{Ma}$ (McDowell and Keizer, 1977; Allan, 1986; Moore et al., 1994; Ferrari et al., 2012). About $11 \mathrm{Ma}$ another pulse of regional volcanic activity occurred (Fig. 2). Evidence of these volcanic pulses is seen in the detrital zircon fission track ages from a sandstone sample collected from the formation of San Jose (Fig. 5) suggesting that a fluvial connection between the regions to the north and the Jalisco block existed. This may be evidence that the Tepic-Zacoalco graben did not exist until after ca. 4.5 Ma, the youngest age peak in our sample. This agrees generally with the previous work of Rosas-Elguera et al. (1996) and Ferrari and Rosas-Elguera (2000) who show that extensional deformation along the complex series of faults that are often lumped together as the Tepic-Zacoalco graben began in the Late Miocene or Early Pliocene.

Righter and Rosas-Elguera (2001) proposed that the sedimentary deposits in the Tecolotlan basin accumulated in a nonextensional, tectonic depression during the Late Miocene before $5 \mathrm{Ma}$. In contrast, our mapping and isotopic dating suggest that EW-extension, normal faulting, and volcanism began in the Late Miocene to Early Pliocene (before ca. $5 \mathrm{Ma}$ ), as evidenced by the cross-cutting faults, accumulation of fluvial and lacustrine sediment (formation of San Jose), and the ages of vertebrate fossils. Diverse magmas (minette, transitional and calc-alkaline) with subduction-signatures erupted along the graben. Local lava flows may have partially or completely blocked the drainage system during deposition of the formation of San Jose (the pile of mafic lavas at the south end of the map area is over $100 \mathrm{~m}$ thick). This period of volcanism and E-W extension corresponds to a flareup of rhyolite ignimbrites in the Tepic-Zacoalco graben to the north (Fig. 1) and perhaps to the initial stages of rifting of the Jalisco block away from North America (Frey et al., 2007). Hydrous mafic lavas formed in this area even though Ferrari et al. (2012) proposed that the wedge above the Rivera Plate was less hydrous than to the east above the Cocos Plate.

Extension during subduction and volcanism at this time may be due to accelerated rollback of the descending slab beginning at ca. 5 Ma as proposed by Ferrari et al. (2001; 2012), precisely the timing of the pulse of volcanic activity and start of sediment accumulation (Late Hemphillian) in the Tecolotlan graben. The volcanic rocks of Tecolotlan mark the front of the Pliocene arc as it migrated southward as the slab rolled back (Fig. 18). The volcanic front reached the Tecolotlan, Ayutla, Mascota, and Los Volcanes areas ca. 4-5 Ma. Ferrari et al. $(2001 ; 2012)$ suggest that slab rollback induced lateral flow of the deep asthenosphere into an enlarging wedge of mantle above the subducting slab (Fig. 19). They, Luhr (1997) and Righter and Rosas-Elguera (2001), all consider the source of alkaline volcanic transitional series and related minettes to be "enriched mantle" in the asthenosphere. Petrone et al. (2003) propose that the magmas have heterogeneous sources with enriched mantle giving rise to the Na-alkaline series and a combination of mantle and subduction components (LILE-rich fluids/melts derived from the down going slab) forming the calcalkaline to transitional series. Vigouroux et al. (2008) expanded on this idea to conclude that enriched mantle, a subduction zone fluid, and previously metasomatized mantle participated in genesis of the calc-alkaline to potassic magmas. Moreover, they point out that since garnet appears to be in the source of the minettes, they are unlikely to have been generated in lithospheric mantle and instead must form in the asthenosphere within the mantle wedge. The abundance of potassic magmas at the volcanic front is attributed to metasomatism of the forearc wedge (stabilizing 

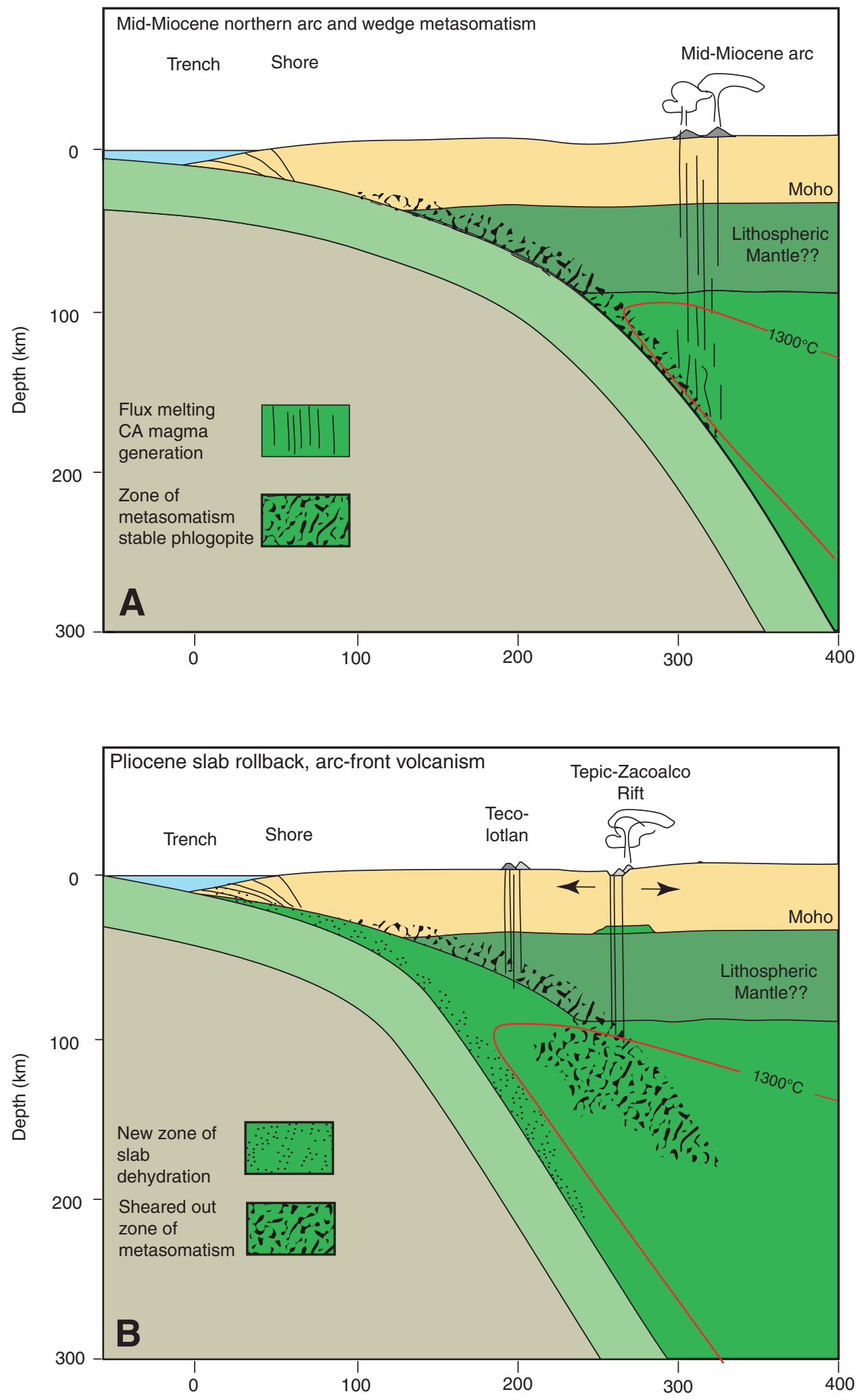

Figure 19. Tectonic model for the formation of minette and transitional series along with a normal calc-alkaline suite on the Jalisco block related to slab rollback (Vigouroux et al., 2008). Isotherms are a generalization of those calculated in Ferrari et al. (2012). (A). During the Miocene, the volcanic arc was to the north and apparently related to low-angle subduction. Dehydration of the subducting slab hydrated and metasomatized the mantle wedge (shaded region) and at deeper levels dehydration triggered melting of the hotter wedge and subduction zone volcanism. (B) Following steepening of the slab, this metasomatized zone was dragged toward the trench and downward by slab movement and corner flow into higher temperature part of the wedge. Variable degrees of incorporation of the metasomatized material in the partial melting zone created a range of derivative melts from potassic minettes to transitional or "normal" calc-alkaline magmas (e.g., Luhr, 1997) as seen on the Jalisco block. Alternatively, corner flow could bring hot mantle into contact with the metasomatized base of the lithosphere at the arc front and induce partial melting. However, Manea and Manea (2011) contend there is no lithospheric mantle beneath southern Mexico. 
phlogopite) by mid-Miocene (or older) subduction at a shallow angle. This is followed in the Pliocene by steepening of the slab, migration of the arc front to the south, and incorporation of the previously metasomatized region into the magma source region (Fig. 19). Melting is driven by ongoing dehydration of the steeply subducting slab.

We concur with these conclusions and propose that the calcalkaline suite was produced by slab dehydration and flux melting of the mantle and that the minettes were produced by small degrees of melting of previously veined, phlogopite-bearing metasomatized mantle. Both types are wet, oxidized, and have distinctive enrichments of soluble elements. The chemical character of Tecolotlan's transitional magmas, with their significant, but small $\mathrm{Nb}$-anomalies, argues that magmas involved components from both the calc-alkaline series and the minettes, but also from a component like the Na-alkaline series erupted to the north (Figs. 16 and 20). Mixing might have occurred in the mantle wedge or crust to create trachybasalt, which then fractionated at high pressure where plagioclase was unstable to produce the evolved trachyandesites. Clinopyroxene and garnet dominated the fractionating mineral assemblage. The high pressure differentiation produced strong enrichments of incompatible elements and high $\mathrm{Sr} / \mathrm{Y}$ ratios in the most evolved trachyandesites (Fig. 16). Extension was not sufficient to generate or tap un-hybridized magmas of the Na-alkaline series that erupted in the TepicZacoalco graben.

The formation of the Tecolotlan graben appears to coincide with a widespread phase of diffuse, non-localized extension in the Jalisco Block during the period of slab rollback and arcfront magmatism. The close association of arc-front volcanism and extension suggests extension may have been necessary for

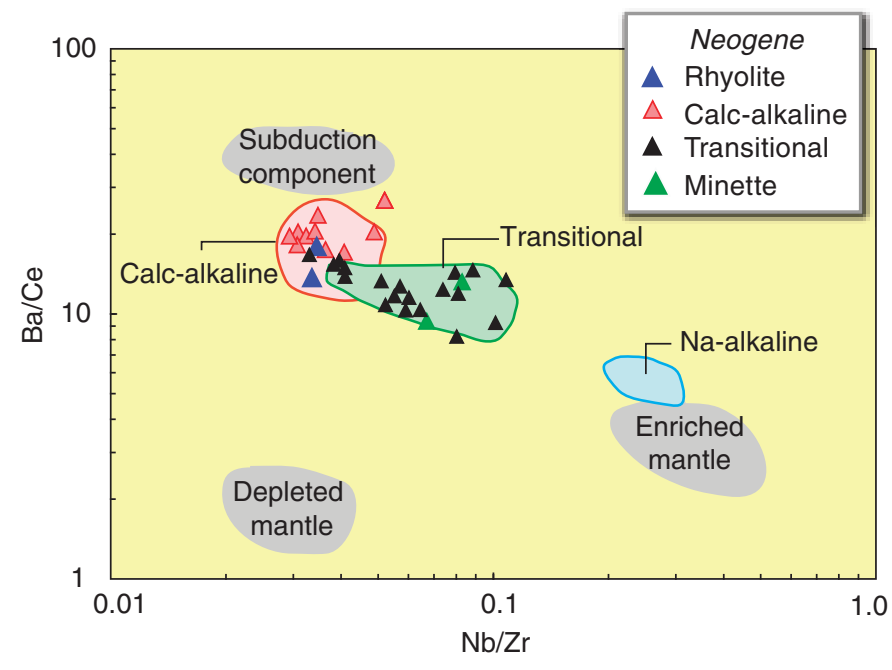

Figure 20. The high $\mathrm{Ba} / \mathrm{Ce}$ and low $\mathrm{Nb} / \mathrm{Zr}$ ratios of the calc-alkaline series is consistent with the addition of subduction zone fluids. The composition of the transitional series lies between the calc-alkaline rocks and an unerupted Na-alkaline series seen in the region. Fields from Ferrari et al. (2001) and Petrone et al. (2003). magma generation in the fore arc or at the arc front (Fig. 1). However, this model provides no explanation of the brief interval of EW extension and normal faulting. The EW extension was likely related to extensional opening of the northern Colima rift, which occurred ca. 5 Ma (Allan, 1986; Allan et al., 1991; RosasElguera et al., 1996; Norini et al., 2010), but was terminated once the Tepic-Zacoalco rift started to form in middle to late Miocene (Ferrari et al., 2012) and was sufficiently developed by slab rollback and trench suction.

\section{Post-Rift History}

Sometime after ca. 3.6 Ma, the lower energy deposits of the formation of San Jose were truncated by an erosional surface onto which the coarser, higher energy deposits of the formation of San Buenaventura were laid down. Rifting and volcanism within the graben also ceased at this time. This change in sedimentation from fine-grained fluvial-lacustrine beds to coarse clastic alluvial fan deposits was likely due to processes related to the change in volcanism/tectonism, likely assisted by climatic changes. First, with the end of volcanic activity, lava flows no longer dammed up the valley allowing for downcutting and a drop in local base level. Second, once active rifting ceased, coarse clastic material was able to prograde out across the basin, perhaps similar to the observations of Paola (1988) and Heller et al. (1988) on the progradation of coarse material into a foreland basin once active thrusting ceases - albeit on a much smaller scale. This type of sediment change has been observed in other extensional basins (Blair, 1987; Blair and Bilodeau, 1988; DiGiuseppi and Bartley, 1991). For example, DiGiuseppi and Bartley (1991) showed that fine-grained lacustrine and alluvial sediments of the Neogene White River Narrows Formation in Nevada changed to coarsegrained prograding fan deposits when rifting ceased and the internally drained basin became integrated into the larger Colorado River drainage.

The character of Pleistocene climate change in west central Mexico appears to be quite variable and still rather poorly understood (Metcalfe et al., 2000; Metcalfe, 2006; Lozano-García et al., 2013); however, the climate was certainly cooler, a condition that would have influenced soils, vegetation, and erosion. OlivaUrcia et al. (2016) studied Late Pleistocene sediments in the Añavieja Basin in Spain and observed "that during cold periods, a sparser vegetation cover favored the incoming of higher energy runoff bearing coarser sediments to the basin...." A similar situation may have occurred in the Tecolotlan graben with cooler temperatures and less vegetation stimulating the production of coarser detritus.

Subsequent extension was localized in the major bounding grabens (the Colima and Tepic-Zacoalco grabens). These grabens started to form and have continued to extend and be volcanically active until today. As a result, these grabens are broader, deeper, and have more abundant young volcanic rocks (Fig. 1). Currently, the rate of extension is $\sim 5-6 \mathrm{~mm} /$ year for these larger grabens (Selvans et al., 2010). This pattern of early diffuse 
extension followed by more focused extension matches the predicted pattern of extensional deformation given by the numerical modeling work of Cowie (1998) and Cowie et al. (2000).

The localized lithospheric extension also captured the subduction zone magmatism, focusing eruption sites in the grabens to the north and east. Contemporaneous eruption of alkaline and calc-alkaline magmas attest to the results of ongoing extension and subduction. Extension in Tepic-Zacoalco graben is sufficient to allow some basalts of the Na-alkaline series to erupt separately without mixing with the calc-alkaline series.

\section{Regional Comparison of Sedimentary Successions}

The Hemphillian and Late Blancan age sediments found in the Tecolotlan graben show similarities and differences compared to coeval deposits in the other basins across central Mexico For example, the Hemphillian formation of San Jose is similar in lithology (mostly fine grained silts and sands, with some caliche layers) and depositional setting (fluvial/lacustrine) to the Hemphillian Rancho El Ocote and the Blancan Rancho Viejo beds deposited $350 \mathrm{~km}$ ENE of Tecolotlan in the San Miguel de Allende basin in the State of Guanajuato (CarranzaCastañeda et al., 1994; Adams, 2001). The Rancho El Ocote and Rancho Viejo beds range in age from ca. 3 to 5 Ma (Kowallis et al., 1998; Adams, 2001; Adams et al., 2006), while the formation of San Jose is ca. 3.6-5 Ma. The deposits in the San Miguel de Allende basin have a well-preserved assemblage of vertebrate fossils (Miller and Carranza-Castañeda, 1984, 1998a; Carranza-Castañeda and Miller, 1996; Carranza-Castañeda et al., 2000; Miller and Carranza-Castañeda, 2001b) that is comparable with the one found in the formation of San Jose in the Tecolotlan graben. The Rancho el Ocote and Rancho Viejo formations in Guanajuato, however, contain many more silicic fallout tuff beds and they lack young ( $<5 \mathrm{Ma}$ ) locally erupted volcanic rocks like those in the Tecolotlan graben. In addition, no sediments equivalent in age to the Late Blancan/Irvingtonian formation of San Buenaventura occur in the San Miguel de Allende basin.

\section{CONCLUSIONS}

Rocks of the Tecolotlan graben in west-central Mexico record a history beginning with the Cretaceous accretion of the Guerrero arc terrane, then through a period of Neogene extension, volcanism, and sedimentation, and finally to Neogene and Quaternary post-extension alluvial fan deposition and downcutting of the modern drainage. The valley is host to significant fossil mammal bearing strata of Blancan to Irvingtonian age (North American land mammal ages).

The older Cretaceous rocks in the Tecolotlan area consist of carbonate and clastic sedimentary rocks, plutonic rocks, and proximal volcanic and volcaniclastic rocks that formed in or near a subduction-related volcanic arc built on already established continental crust, not as part of an island arc that became accreted to North America. We propose that the situation in the
Cretaceous may have been similar to that in the late Cenozoic where calc-alkaline and slightly alkaline suites erupted simultaneously in a rifting arc that was also accumulating considerable amounts of sediment. These Cretaceous rocks were subsequently folded, uplifted, and eroded prior to deposition of overlying Neogene and Quaternary sediments.

Cenozoic faulting, volcanism, and sedimentation in the Tecolotlan graben is reflective of a period of relatively diffuse early to late Pliocene extension that created small graben structures with limited sedimentation $(<100 \mathrm{~m})$ throughout the Jalisco block but then ceased to be active by ca. 3.5-2.5 Ma.

This contrasts with the thick, and relatively continuous, Miocene to Recent packages of volcanic and sedimentary rock found in the Tepic-Zacoalco and Colima rifts-major grabens bounding the Jalisco block (Allan, 1986; Allan et al., 1991; Michaud et al., 2000). Extension and associated sedimentation began in the Tecolotlan graben at ca. $5 \mathrm{Ma}$, approximately the same time as rifting and related volcanism began along the Colima Rift, which parallels the Tecolotlan graben to the east (Allan, 1986; Moore et al., 1994; Rosas-Elguera et al., 1996; Ferrari et al., 2000; 2012; Selvans et al., 2010). The lack of evidence for any modern fault activity in the graben suggests that the larger Colima and TepicZacoalco grabens are accommodating any regional extension that is still occurring, and that the smaller grabens, like the Tecolotlan graben, have become essentially inactive.

At ca. 3.6 Ma, when extension and volcanism ceased in the Tecolotlan graben, the Hemphillian-Early Blancan fine-grained deposits were truncated by an erosional surface onto which coarser Late Blancan-Irvingtonian deposits were laid down. This change in sedimentation may have been influenced by several factors including the end of active rifting, downcutting through lava flows that blocked the south end of the valley, and by Pleistocene climatic cooling.

\section{ACKNOWLEDGMENTS}

We thank Brigham Young University and the Universidad Nacional Autónoma de México for support during the course of this research, which was funded by NSF Grant EAR-9902898 and UNAM proyecto PAPIIT IN109814. BYU student David Shore assisted during one field excursion and Gerardo Alvarez-Reyes provided extensive support during multiple trips to the field area for which we are deeply grateful. We also greatly appreciate the helpful and thorough comments of two anonymous GSA reviewers.

\section{REFERENCES CITED}

Adams, A.J., 2001, Late Cenozoic sedimentation in the San Miguel de Allende Basin, Guanajuato, Mexico [M.S. thesis]: Brigham Young University, $95 \mathrm{p}$.

Adams, A.J., Christiansen, E.H., Kowallis, B.J., Carranza-Castañeda, O., and Miller, W.E., 2006, Contrasting silicic magma series in Miocene-Pliocene ash deposits in the San Miguel de Allende graben, Guanajuato, Mexico: The Journal of Geology, v. 114, p. 247-266, doi:10.1086/499633.

Allan, J.F., 1986, Geology of the northern Colima and Zacoalco grabens, southwest Mexico: Late Cenozoic rifting in the Mexican Volcanic Belt: 
Geological Society of America Bulletin, v. 97, p. 473-485, doi:10 $.1130 / 0016-7606(1986) 97<473:$ GOTNCA>2.0.CO;2.

Allan, J.F., Nelson, S.A., Luhr, J.F., Carmichael, I.S.E., Wopat, M., and Wallace, P.J., 1991, Pliocene-Holocene rifting and associated volcanism in southwest Mexico: an exotic terrane in the making, in Dauphin, J.P. and Simoneit, B.R.T., eds., The Gulf and Peninsular Province of the Californias: American Association of Petroleum Geologists Memoir 47, p. $425-445$.

Allmendinger, R.W., Cardozo, N.C., and Fisher, D., 2013, Structural Geology Algorithms: Vectors \& Tensors: Cambridge, England, Cambridge University Press, $289 \mathrm{p}$.

Bandy, W.L., Hilde, T.W.C., and Yan, C.-Y., 2000, The Rivera-Cocos plate boundary: Implications for Rivera-Cocos relative motion and plate fragmentation, in Delgado-Granados, H., Aguirre-Díaz, G., and Stock, J.M., eds., Cenozoic Tectonics and Volcanism of Mexico: Geological Society of America Special Paper 334, p.1-28, doi:10.1130/0 $-8137-2334-5.1$

Blair, T.C., 1987, Tectonic and hydrologic controls on cyclic alluvial fan, fluvial, and lacustrine rift-basin sedimentation, Jurassic-lowermost Cretaceous Todos Santos Formation, Chiapas, Mexico: Journal of Sedimentary Petrology, v. 57, p. 845-862.

Blair, T.C., and Bilodeau, W.L., 1988, Development of tectonic cyclothems in rift, pull-apart, and foreland basins: sedimentary response to episodic tectonism: Geology, v. 16, p. 517-520, doi:10.1130/0091-7613(1988) 016<0517:DOTCIR >2.3.CO;2.

Blatter, D.L., and Carmichael, I.S., 1998, Plagioclase-free andesites from Zitacuaro (Michoacan), Mexico: petrology and experimental constraints: Contributions to Mineralogy and Petrology, v. 132, no. 2, p. 121-138, doi:10.1007/s004100050411.

Bryan, S.E., Orozco-Esquivel, T., Ferrari, L., and López- Martínez, M., 2014, Pulling apart the mid to late Cenozoic magmatic record of the Gulf of California: Is there a Comondú arc?, in Gómez-Tuena, A., Straub, S.M., and Zellmer, G.F., eds., Orogenic Andesites and Crustal Growth: Geological Society of London Special Publication 385, p. 389-407.

Campa, M.F., and Coney, P.J., 1983, Tectono-stratigraphic terranes and mineral resource distributions in Mexico: Canadian Journal of Earth Sciences, v. 20, p. 1040-1051, doi:10.1139/e83-094.

Campa, M.F., and Ramirez, J., 1979, La evolución geologica y la metalogenesis del noroccidente de Guerrero: Guerrero, Mexico: Serie tecnico cientifica, Universidad de Guerrero, $102 \mathrm{p}$.

Campa, M.F., Oviedo, R., and Tardy, M., 1976, La cabalgadura laramídica del dominio volcano-sedimentario (Arco de Alisitos-Teloloapan) sobre el miogeosinclinal mexicano en los límites de los estados de Guerrero y México: III Congreso Latino-Americano de Geología, México, Resúmenes, p. 23.

Campbell, K.E., Jr., Prothero, D.R., Romero-Pittman, L., Hertel, F., and Rivera, N., 2010, Amazonian magnetostratigraphy; dating the first pulse of the Great American Faunal Interchange: Journal of South American Earth Sciences, v. 29, p. 619-626, doi:10.1016/j.jsames.2009.11.007.

Carbot-Chanona, G., Juarez-Woo, J., and Guzman-Gutierrez, J.R., 2009, Contribucion al conocimiento de los rinocerontes fosiles de la Cuenca de Tecolotlan, en el estado de Jalisco, Mexico: Boletin de la Sociedad Geologica Mexicana, v. 61, p. 277-286.

Cardozo, N., and Allmendinger, R.W., 2013, Spherical projections with OSXStereonet: Computers \& Geosciences, v. 51, p. 193-205, doi:10.1016/j .cageo.2012.07.021.

Carmichael, I.S.E., Lange, R.A., and Luhr, J.F., 1996, Quaternary minettes and associated volcanic rocks of Mascota, western Mexico: a consequence of plate extension above a subduction-modified mantle wedge: Contributions to Mineralogy and Petrology, v. 124, p. 302-333, doi:10.1007/ s004100050193.

Carranza-Castañeda, O., and Miller, W.E., 1980, The earliest capybara record in North America: Geological Society of America Abstracts with Programs, v. 12 , no. 7 , p. 399 .

Carranza-Castañeda, O., and Miller, W.E., 1996, Hemphillian and Blancan age felids from central Mexico: Journal of Paleontology, v. 70, p. 509-518, doi: $10.1017 /$ S0022336000038439.

Carranza-Castañeda, O., and Miller, W.E., 2002, Paleontology and stratigraphy of the Tecolotlan basin, Jalisco, Mexico: Journal of Vertebrate Paleontology, v. 22 , no. 3 , p. $41 \mathrm{~A}-42 \mathrm{~A}$.

Carranza-Castañeda, O., and Miller, W.E., 2004, Late Tertiary terrestrial mammals from central Mexico and their relationship to South American immi- grants: Revista Brasileira de Paleontologia, v. 7, p. 249-261, doi:10.4072/ rbp.2004.2.19.

Carranza-Castañeda, O., Ferrusquia, I., and Miller, W.E., 1981, Roedpres cavopmorphos Pliocénicos de la región central de México: Porto Alegre, Brazil: Congreso Latinamericano Paleontología Anales, v. 2, p. 721-729.

Carranza-Castañeda, O., Petersen, M.S., and Miller, W.E., 1994, Preliminary investigation of the geology of the northern San Miguel Allende area, northeastern Guanajuato, Mexico: Brigham Young University Geology Studies, v. 40, p. $1-10$.

Carranza-Castañeda, O., Miller, W.E., and Kowallis, B.J., 2000, Recent discoveries of South American immigrants and faunas from central Mexico with radiometric dates [abs.]: Journal of Vertebrate Paleontology, v. 20, no. 3 , p. $34 \mathrm{~A}$

Centeno-García, E., Ruiz, J., Coney, P.J., Patchett, P.J., and Ortega-Gutiérrez, F., 1993, Guerrero terrane of Mexico: Its role in the southern Cordillera from new geochemical data: Geology, v. 21, p. 419-422, doi:10.1130/0091 -7613(1993)021<0419:GTOMIR>2.3.CO;2.

Centeno-García, E., Corona-Chavez, P., Talavera-Mendoza, O., and Iriondo, A., 2003, Geology and tectonic evolution of the Western Guerrero terraneA transect from Puerto Vallarta to Zihuatanejo, México, in Alcayde, M. and Gómez-Caballero, A., eds., Geologic Transects across Cordilleran México: Guidebook for Field Trips of the 99th GSA Cordilleran Section Meeting: Universidad Nacional Autónoma de México, Instituto de Geología Publicación Especial 1, p. 201-228.

Centeno-García, E., Busby, C., Busby, M., and Gehrels, G., 2011, Evolution of the Guerrero composite terrane along the Mexican margin, from extensional fringing arc to contractional continental arc: Geological Society of America Bulletin, v. 123, p. 1776-1797, doi:10.1130/B30057.1.

Cerca, M., Ferrari, L., López-Martínez, M., Martiny, B., and Iriondo, A., 2007, Late Cretaceous shortening and early Tertiary shearing in the central Sierra Madre del Sur, southern Mexico: Insights into the evolution of the Caribbean-North American plate interaction: Tectonics, v. 26, TC3007, 34 p., doi:10.1029/2006TC001981.

Chesner, C.A., Rose, W.I., Deino, A.L., Drake, R., and Westgate, J.A., 1991, Eruptive history of Earth's largest Quaternary caldera (Toba) clarified: Geology, v. 19, p. 200-203, doi:10.1130/0091-7613(1991)019<0200 $:$ EHOESL $>2.3 . \mathrm{CO} ; 2$.

Corona-Esquivel, R., and Alencáster, G., 1995, Rudists from the Peña Colorada iron mine and La Minita sulfide deposit, states of Colima and Michoacán, SW Mexico: Revista Mexicana de Ciencias Geológicas, v. 12, no. 2, p. $185-190$

Cowie, P.A., 1998, A healing-reloading feedback control on the growth rate of seismogenic faults: Journal of Structural Geology, v. 20, p. 1075-1087, doi:10.1016/S0191-8141(98)00034-0.

Cowie, P.A., Gupta, S., and Dawers, N.H., 2000, Implications of fault array evolution for synrift depocentre development: insights from a numerical fault growth model: Basin Research, v. 12, p. 241-261, doi:10.1046/ j.1365-2117.2000.00126.x.

Crummy, J.M., Savov, I.P., Navarro-Ochoa, C., Morgan, D.J., and Wilson, M. 2014, High-K mafic plinian eruptions of Volcán de Colima, Mexico: Journal of Petrology, v. 55, p. 2155-2192, doi:10.1093/petrology/egu053.

Deino, A.L., and Potts, R., 1990, Single-crystal ${ }^{40} \mathrm{Ar} /{ }^{39} \mathrm{Ar}$ dating of the Olorgesailie Formation, southern Kenya rift: Journal of Geophysical Research, v. 95 , p. 8453-8470, doi:10.1029/JB095iB06p08453.

Deino, A.L., Tauxe, L., Monathan, M., and Drake, R., 1990, Single-crystal ${ }^{40} \mathrm{Ar} /{ }^{39} \mathrm{Ar}$ ages and the litho- and paleomagnetic stratigraphies of the Ngorora Formation, Kenya: The Journal of Geology, v. 98, p. 567-587, doi:10.1086/629425.

Dickinson, W.R., 1985, Interpreting provenance relations from detrital modes of sandstones, in Zuffa, G.G., ed., Provenance of arenites: NATO Advanced Study Institute Series 148: Dordrecht, Netherlands, D. Reidel, p. 333-361, doi:10.1007/978-94-017-2809-6_15.

Dickinson, W.R., Klute, M.A., Hayes, M.J., Janecke, S.U., Lundin, E.R., McKittrick, M.A., and Olivares, M.D., 1988, Paleogeographic and paleotectonic setting of Laramide sedimentary basins in the central Rocky Mountain region: Geological Society of America Bulletin, v. 100 , p. 1023-1039, doi:10.1130/0016-7606(1988)100<1023 :PAPSOL $>2.3 . \mathrm{CO} ; 2$

DiGiuseppi, W.H., and Bartley, J.M., 1991, Stratigraphic effects of change from internal to external drainage in an extending basin, southeastern Nevada: Geological Society of America Bulletin, v. 103, p. 48-55, doi:10.1130/0016-7606(1991)103<0048:SEOCFI>2.3.CO;2. 
Dott, R.H., Jr., 1964, Wacke, graywacke and matrix-What approach to immature sandstone classification?: Journal of Sedimentary Petrology, v. 34, p. 625-632.

Drummond, M.S., Defant, M.J., and Kepezhinskas, P.K., 1996, Petrogenesis of slab-derived trondhjemite-tonalite-dacite/adakite magmas, in Brown, M., et al., eds., The Third Hutton Symposium on the Origin of Granites and Related Rocks: Geological Society of America. Special Paper 315 , p. 205-215, doi:10.1130/0-8137-2315-9.205.

Duque-Trujillo, J., Ferrari, L., Orozco-Esquivel, T., López-Martínez, M., Lonsdale, P., Bryan, S.E., Kluesner, J., Piñero-Lajas, D., and Solari, L., 2015, Timing of rifting in the southern Gulf of California and its conjugate margins: Insights from the plutonic record: Geological Society of America Bulletin, v. 127, p. 702-736, doi:10.1130/B31008.1.

Ferrari, L., and Rosas-Elguera, J., 2000, Late Miocene to Quaternary extension at the northern boundary of the Jalisco block, western Mexico: The Tepic-Zacoalco rift revised, in Delgado-Granados, H., Aguirre-Díaz, G., and Stock, J.M., eds. Cenozoic Tectonics and Volcanism of Mexico: Geological Society of America Special Paper 334, p. 41-63, doi:10.1130/0-8137-2334-5.41.

Ferrari, L., Pasquaré, G., Venegas, S., Castillo, D., and Romero, F., 1994 Regional tectonics of western Mexico and its implications for the northern boundary of the Jalisco block: Geofísica Internacional, v. 33, p. 139-151.

Ferrari, L., Pasquaré, G., Venegas-Salgado, S., and Romero-Rios, F., 2000 Geology of the western Mexican Volcanic Belt and adjacent Sierra Madre Occidental and Jalisco block, in Delgado-Granados, H., Aguirre-Díaz, G., and Stock, J.M., eds., Cenozoic Tectonics and Volcanism of Mexico: Geological Society of America Special Paper 334, p. 65-83, doi:10.1130/0 $-8137-2334-5.65$.

Ferrari, L., Petrone, C.M., and Francalanci, L., 2001, Generation of oceanicisland basalt-type volcanism in the western Trans-Mexican volcanic belt by slab rollback, asthenosphere infiltration, and variable flux melting: Geology, v. 29, p. 507-510, doi:10.1130/0091-7613(2001)029<0507 :GOOIBT>2.0.CO;2.

Ferrari, L., López-Martínez, M., and Rosas-Elguera, J., 2002, Ignimbrite flareup and deformation in the southern Sierra Madre Occidental, western Mexico-implications for the late subduction history of the Farallon Plate: Tectonics, v. 21, doi:10.1029/2001TC001302.

Ferrari, L., Valencia-Moreno, M., and Bryan, S., 2007, Magmatism and tectonics of the Sierra Madre Occidental and its relation with the evolution of the western margin of North America, in Alaniz-Álvarez, S.A., and NietoSamaniego, Á.F., eds., Geology of México: Celebrating the Centenary of the Geological Society of México: Geological Society of America Special Paper 422, p. 1-39, doi: 10.1130/2007.2422(01).

Ferrari, L., Orozco-Esquivel, T., Manea, V., and Manea, M., 2012, The dynamic history of the Trans-Mexican Volcanic Belt and the Mexico subduction zone: Tectonophysics, v. 522-523, p. 122-149, doi:10.1016/j .tecto.2011.09.018.

Ferrari, L., López-Martínez, M., Orozco-Esquivel, T., Bryan, S.E., DuqueTrujillo, J., Lonsdale, P., and Solari, L., 2013, Late Oligocene to Middle Miocene rifting and synextensional magmatism in the southwestern Sierra Madre Occidental, Mexico: The beginning of the Gulf of California rift: Geosphere, v. 9, n. 5, 40 p., doi:10.1130/GES000925.1.

Ferrari, L., Bergomi, M., Martini, M., Tunesi, A., Orozco-Esquivel, T., and López-Martínez, M., 2014, Late Cretaceous-Oligocene magmatic record in southern Mexico: The case for a temporal slab window along the evolving Caribbean-North America-Farallon triple boundary: Tectonics, v. 33, p. 1738-1765, doi:10.1002/2014TC003525.

Flynn, J.J., Kowallis, B.J., Nuñez, C., Carranza-Castañeda, O., Miller, W.E., Swisher, C.C., and Lindsay, E., 2005, Geochronology of HemphillianBlancan aged strata, Guanajuato, Mexico, and implications for timing of the Great American Biotic Interchange: The Journal of Geology, v. 113, p. 287-307, doi:10.1086/428806.

Folk, R.L., 1974, Petrology of sedimentary rocks: Austin, Texas, Hemphill Publishing Company, $182 \mathrm{p}$

Frey, H.M., Lange, R.A., Hall, C.M., and Delgado-Granados, H., 2004, Magma eruption rates constrained by ${ }^{40} \mathrm{Ar} /{ }^{39} \mathrm{Ar}$ chronology and GIS for the Ceboruco-San Pedro volcanic field, western Mexico: Geological Society of America Bulletin, v. 116, p. 259-276, doi: 10.1130/B25321.1.

Frey, H., Lange, R.A., Hall, C.M., Delgado-Granados, H., and Carmichael, I.S.E., 2007, A Pliocene ignimbrite flare-up along the Tepic-Zacoalco rift: evidence for the initial stages of rifting between the Jalisco block (Mexico) and North America: Geological Society of America Bulletin, v. 119, p. 49-64, doi:10.1130/B25950.1.
Freydier, C., Lapierre, H., Briqueu, L., Tardy, M., Coulon, C., and MartinezReyes, J., 1997, Volcaniclastic sequences with continental affinities within the Late Jurassic-Early Cretaceous Guerrero intra-oceanic arc terrane (western Mexico): The Journal of Geology, v. 105, p. 483-502, doi:10.1086/515941.

Frost, B.R., Barnes, C.G., Collins, W.J., Arculus, R.J., Ellis, D.J., and Frost, C.D., 2001, A geochemical classification for granitic rocks: Journal of Petrology, v. 42, no. 11, p. 2033-2048, doi:10.1093/petrology/42.11.2033.

Gill, J.B., 1981, Orogenic andesites and plate tectonics: Berlin, Springer Verlag, 401 p, doi:10.1007/978-3-642-68012-0

Green, P.F., 1981, A new look at statistics in fission track dating: Nuclear Tracks, v. 5, p. 77-80, doi:10.1016/0191-278X(81)90029-9.

Gómez-Tuena, A., Langmuir, C.H., Goldstein, S.L., Straub, S.M., and OrtegaGutiérrez, F., 2006, Geochemical evidence for slab melting in the TransMexican Volcanic Belt: Journal of Petrology, v. 48, no. 3, p. 537-562, doi:10.1093/petrology/eg1071

Gómez-Tuena, A., Orozco-Esquivel, M.T., and Ferrari, L., 2007, Igneous petrogenesis of the Trans-Mexican Volcanic Belt, in Alaniz-Álvarez, S.A., and Nieto-Samaniego, Á.F., eds., Geology of México: Celebrating the Centenary of the Geological Society of México: Geological Society of America Special Paper 422, p. 129-181, doi:10.1130/2007.2422(05).

Heller, P.L., Angevine, C.L., Winslow, N.S., and Paola, C., 1988, Two-phase stratigraphic model of foreland-basin sequences: Geology, v. 16, p. 501504, doi:10.1130/0091-7613(1988)016<0501:TPSMOF>2.3.CO;2.

Hurford, A.J., Fitch, F.J., and Clarke, A., 1984, Resolution of the age structure of the detrital zircon populations of two Lower Cretaceous sandstones from the Weald of England by fission track dating: Geological Magazine, v. 121, p. 269-277, doi:10.1017/S0016756800029162.

Köhler, H., Schaaf, P., Müller-Sohnius, D., Emmerman, R., Negendank, J.F.W. and Tobschall, H.J., 1988, Geochronological and geochemical investigations on plutonic rocks from the complex of Puerto Vallarta, Sierra Madre del Sur: Geofísica Internacional, v. 27, p. 519-542.

Kowallis, B.J., Heaton, J.S., and Bringhurst, K., 1986, Fission-track dating of volcanically derived sedimentary rocks: Geology, v. 14, p. 19-22, doi:10.1130/0091-7613(1986)14<19:FDOVDS>2.0.CO;2.

Kowallis, B.J., Christiansen, E.H., Deino, A.L., Kunk, M.J., and Heaman, L.M., 1995, Age of the Cenomanian-Turonian boundary in the Western Interior of the United States: Cretaceous Research, v. 16, p. 109-129, doi:10.1006/cres.1995.1007.

Kowallis, B.J., Swisher, C.C., Carranza-Castañeda, I.I.I., Miller, W.E., and Tingey, D.G., 1998, Fission-track and single-crystal ${ }^{40} \mathrm{Ar}{ }^{\beta 9} \mathrm{Ar}$ laser-fusion ages from volcanic ash layers in fossil-bearing Pliocene sediments in central Mexico: Revista Mexicana de Ciencias Geológicas, v. 15, p. 157-160.

Kuiper, K.F., Deino, A.L., Hilgen, F.J., Krijgsman, W., Renne, P.R., and Wijbrans, J.R., 2008, Synchronizing rock clocks of Earth history: Science, v. 320 , p. 500-504, doi:10.1126/science. 1154339 .

Lange, R.A., and Carmichael, I.S.E., 1990, Hydrous basaltic andesites associated with minette and related lavas in western Mexico: Journal of Petrology, v. 31, p. 1225-1259, doi:10.1093/petrology/31.6.1225.

Le Maitre, R.W., 1989, A Classification of Igneous Rocks and Glossary of Terms: Recommendations of the IUGS Subcommission on the Systematics of Igneous Rocks: London, Blackwell Scientific, 193 p.

Lozano-García, S., Torres-Rodríguez, E., Ortega, B., Vázquez, G., and Caballero, M., 2013, Ecosystem responses to climate and disturbances in western central Mexico during the late Pleistocene and Holocene: Palaeogeography, Palaeoclimatology, Palaeoecology, v. 370, p. 184-195, doi:10 .1016/j.palaeo.2012.12.006.

Lucas, S.G., 2008, The rhinoceros Teleoceras from the Miocene of Jalisco, Mexico: Bulletin, New Mexico Museum of Natural History and Science, v. 44, p. $65-69$.

Luhr, J.F., 1997, Extensional tectonics and the diverse primitive volcanic rocks in the western Mexican Volcanic Belt: The Canadian Mineralogist, v. 35, p. 473-500.

Luhr, J.F., Allan, J.F., Carmichael, I.S.E., Nelson, S.A., and Hasenaka, T., 1989, Primitive calc-alkaline and alkaline volcanic rock types from the western Mexican Volcanic Belt: Journal of Geophysical Research, v. 94, B4, p. 4515-4530, doi:10.1029/JB094iB04p04515.

Manea, V.C., and Manea, M., 2011, Flat-slab thermal structure and evolution beneath Central Mexico: Pure and Applied Geophysics, v. 168, p. 14751487, doi:10.1007/s00024-010-0207-9.

Maria, A.H., and Luhr, J.A., 2008, Lamprophyres, basanites, and basalts of the western Mexican Volcanic Belt: volatile contents and a vein-wallrock 
melting relationship: Journal of Petrology, v. 49, p. 2123-2156, doi:10 $.1093 /$ petrology/egn060.

Marshall, L.G., 1985, Geochronology and land-mammal biochronology of the transamerican faunal interchange, in Stehli, F.G. and Webb, S.D., eds., The Great American Biotic Interchange: New York, Plenum Press, p. 49-85, doi:10.1007/978-1-4684-9181-4_3.

Martini, M., and Ferrari, L., 2011, Style and chronology of the Late Cretaceous shortening in the Zihuatanejo area (southwestern Mexico): Implications for the timing of the Mexican Laramide deformation: Geosphere, v. 7, p. 1469-1479, doi:10.1130/GES00743.1.

Martini, M., Ferrari, L., López-Martínez, M., Cerca-Martínez, M., Valencia, V.A., and Serrano-Durán, L., 2009, Cretaceous-Eocene magmatism and Laramide deformation in southwestern Mexico: No role for terrane accretion, in Kay, S.M., Ramos, V.A., and Dickinson, D.R., eds., Backbone of the Americas: Shallow Subduction, Plateau Uplift, and Ridge and Terrane Collision: Geological Society of America Memoir 204, p. 151-182, doi:10.1130/2009.1204(07).

Martini, M., Ferrari, L., López-Martínez, M., and Valencia, V., 2010, Stratigraphic redefinition of the Zihuatanejo area, southwestern Mexico: Revista Mexicana de Ciencias Geológicas, v. 27, p. 412-430.

McDowell, F.W., and Keizer, R.P., 1977, Timing of mid-Neogene volcanism in the Sierra Madre Occidental between Durango City and Mazatlan, Mexico: Geological Society of America Bulletin, v. 88, p. 1479-1487, doi:10.1130/0016-7606(1977)88<1479:TOMVIT>2.0.CO;2.

McDowell, F.W., and McIntosh, W.C., 2012, Timing of intense magmatic episodes in the northern and central Sierra Madre Occidental, western Mexico: Geosphere, v. 8, p. 1505-1526, doi:10.1130/GES00792.1.

McDowell, F.W., Roldán-Quintana, J., and Connelly, J.N., 2001, Duration of Late Cretaceous-early Tertiary magmatism in east-central Sonora, Mexico: Geological Society of America Bulletin, v. 113, p. 521-531, doi:10.1130/0016-7606(2001)113<0521:DOLCET>2.0.CO;2.

Mercer, L.T., Kowallis, B.J., Christiansen, E.H., Miller, W.E., CarranzaCastaneda, O., and Israde-Alcantara, I., 2014, Geology of the Tierras Blancas Area in the Southeastern Part of the Acambay Graben, Central Mexico: Geological Society of America Digital Map and Chart 18, 46 p. text, scale 1:10,000, doi:10.1130/2014.DMCH018.

Metcalfe, S.E., 2006, Late Quaternary environments of the northern deserts and central Transvolcanic Belt of Mexico: Annals of the Missouri Botanical Garden, v. 93, no. 2, p. 258-273, doi:10.3417/0026-6493(2006) 93[258:LQEOTN]2.0.CO;2.

Metcalfe, S.E., O'Hara, S.L., Caballero, M., and Davies, S.J., 2000, Records of Late Pleistocene-Holocene climatic change in Mexico-a review: Quaternary Science Reviews, v. 19, p. 699-721, doi:10.1016/S0277 -3791(99)00022-0.

Michaud, F., Gasse, F., Bourgois, J., and Quintero, O., 2000, Tectonic controls on lake distribution in the Jalisco block area (western Mexico), in Delgado-Granados, H., Aguirre-Díaz, G., and Stock, J.M., eds., Cenozoic Tectonics and Volcanism of Mexico: Geological Society of America Special Paper 334, p. 99-110, doi:10.1130/0-8137 $-2334-5.99$.

Miller, W.E., and Carranza-Castañeda, O., 1984, Late Cenozoic mammals from central Mexico: Journal of Vertebrate Paleontology, v. 4, p. 216-236, doi: 10.1080/02724634.1984.10012005.

Miller, W.E., and Carranza-Castañeda, O., 1998a, Late Neogene canids from central Mexico: Journal of Paleontology, v. 72, p. 546-556, doi:10.1017/ S002233600002432X

Miller, W.E., and Carranza-Castañeda, O., 1998b, Importance of late Neogene carnivores and equids from the Transmexican Volcanic Belt: Revista Mexicana de Ciencias Geológicas, v. 15, p. 161-166.

Miller, W.E., and Carranza-Castañeda, O., 1998c, The Tecolotlan basin, central Mexico: a new area for Late Cenozoic terrestrial vertebrates [abs.]: Journal of Vertebrate Paleontology, v. 18, no. 3, p. 64.

Miller, W.E., and Carranza-Castañeda, O., 1999, Early South American immigrants in central Mexico, and times of their appearances [abs.]: Journal of Vertebrate Paleontology, v. 19, no. 3, p. 64A.

Miller, W.E., and Carranza-Castañeda, O., 2001a, New faunal discoveries in the Hemphillian-Blancan basins of central Mexico [abs.]: Journal of Vertebrate Paleontology, v. 21, no. 3, p. 80.

Miller, W.E., and Carranza-Castañeda, O., 2001b, Late Cenozoic mammals from the basins of central Mexico: Bollettino della Società Paleontologica Italiana, v. 40, no. 2, p. 235-242.
Miyashiro, A., 1974, Volcanic rock series in island arcs and active continental margins: American Journal of Science, v. 274, no. 4, p. 321-355, doi:10 .2475/ajs.274.4.321.

Moore, G., and Carmichael, I.S.E., 1998, The hydrous phase equilibria (to $3 \mathrm{kbar}$ ) of an andesite and basaltic andesite from western Mexico: constraints on water content and conditions of phenocryst growth: Contributions to Mineralogy and Petrology, v. 130, p. 304-319, doi:10.1007/ s004100050367.

Moore, G., Marone, C., Carmichael, I.S.E., and Renne, P., 1994, Basaltic volcanism and extension near the intersection of the Sierra Madre volcanic province and the Mexican Volcanic Belt: Geological Society of America Bulletin, v. 106, p. 383-394, doi:10.1130/0016-7606(1994)106<0383 :BVAENT>2.3.CO;2.

Nieto-Samaniego, Á.F., Ferrari, L., Alaniz-Álvarez, S.A., Labarthe-Hernández, G., and Rosas-Elguera, J., 1999, Variation of Cenozoic extension and volcanism across the southern Sierra Madre Occidental volcanic province, Mexico: Geological Society of America Bulletin, v. 111, p. 347-363, doi:10.1130/0016-7606(1999)111<0347:VOCEAV>2.3.CO;2.

Nieto-Samaniego, A.F., Alaniz-Álvarez, S.A., Silva-Romo, G., Eguiza-Castro, M.H., and Mendoza-Rosales, C.C., 2006, Latest Cretaceous to Miocene deformation events in the eastern Sierra Madre del Sur, Mexico, inferred from the geometry and age of major structures: Geological Society of America Bulletin, v. 118, p. 238-252, doi:10.1130/B25730.1.

Norini, G., Capra, L., Groppelli, G., Agliardi, F., Pola, A., and Cortes, A., 2010, Structural architecture of the Colima Volcanic Complex: Journal of Geophysical Research, v. 115, no. B12, doi:10.1029/2010JB007649.

Oliva-Urcia, B., Muñoz, A., Larrasoaña, J.C., Luzón, A., Pérez, A., González, Á., Jiang, Z., Liu, Q., and Román-Berdiel, T., 2016, Response of alluvial systems to Late Pleistocene climate changes recorded by environmental magnetism in the Añavieja Basin (Iberian Range, NE Spain): Geologica Acta, v. 14, no. 2, p. 139-154, doi:10.1344/GeologicaActa2016.14.2.4.

Paola, C., 1988, Subsidence and gravel transport in alluvial basins, in Kleinspehn, K., and Paola, C., eds., New Perspectives in Basin Analysis: New York, Springer-Verlag, p. 231-243, doi:10.1007/978-1-4612-3788-4_11.

Pearce, J.A., 1982, Trace element characteristics of lavas from destructive plate boundaries in Thorpe, R.S., ed., Orogenic andesites and related rocks: Chichester, England, John Wiley and Sons, p. 528-548.

Pearce, J.A., and Cann, J.R., 1973, Tectonic setting of basic volcanic rocks determined using trace element analyses: Earth and Planetary Science Letters, v. 19, p. 290-300, doi:10.1016/0012-821X(73)90129-5.

Pearce, J.A., 1996, A user's guide to basalt discrimination diagrams, in Wyman, D.A., ed., Trace Element Geochemistry of Volcanic Rocks: Applications for Massive Sulphide Exploration: Geological Association of Canada Short Course Notes 12, p. 79-113.

Pearce, J.A., and Norry, M.J., 1979, Petrogenetic implications of Ti, Zr, Y, and $\mathrm{Nb}$ variations in volcanic rocks: Contributions to Mineralogy and Petrology, v. 69, p. 33-48, doi:10.1007/BF00375192.

Pearce, J.A., Harris, N.B.W., and Tindle, A.G., 1984, Trace element discrimination diagrams for the tectonic interpretation of granitic rocks: Journal of Petrology, v. 25, p. 956-983, doi:10.1093/petrology/25.4.956.

Petrone, C.M., and Ferrari, L., 2008, Quaternary adakite-Nb-enriched basalt association in the western Trans-Mexican Volcanic Belt: is there any slab melt evidence?: Contributions to Mineralogy and Petrology, v. 156, p. 73-86, doi:10.1007/s00410-007-0274-9.

Petrone, C.M., Francalanci, L., Carlson, R.W., Ferrari, L., and Conticelli, S., 2003, Unusual coexistence of subduction-related and intraplate-type magmatism; $\mathrm{Sr}, \mathrm{Nd}$ and $\mathrm{Pb}$ isotope and trace element data from the magmatism of the San Pedro-Ceboruco Graben (Nayarit, Mexico): Chemical Geology, v. 193, p. 1-24, doi:10.1016/S0009-2541(02)00229-2.

Renne, P.R., Swisher, C.C., Deino, A.L., Karner, D.B., Owens, T., and DePaolo, D.J., 1998, Intercalibration of Standards, Absolute Ages and Uncertainties in ${ }^{40} \mathrm{Ar} /{ }^{39} \mathrm{Ar}$ Dating: Chemical Geology, Isotope Geoscience Section, v. 145 , p. $117-152$.

Righter, K., and Carmichael, I.S.E., 1996, Phase equilibria of phlogopite lamprophyres from western Mexico: biotite-liquid equilibria and PT estimates for biotite-bearing igneous rocks: Contributions to Mineralogy and Petrology, v. 123, p. 1-21, doi:10.1007/s004100050140.

Righter, K., and Rosas-Elguera, J., 2001, Alkaline lavas in the volcanic front of the Western Mexican Volcanic Belt: geology and petrology of the Ayutla and Tapalpa volcanic fields: Journal of Petrology, v. 42, p. 2333-2361, doi:10.1093/petrology/42.12.2333. 
Righter, K., Carmichael, I.S.E., Becker, T.A., and Renne, P.R., 1995, PlioceneQuaternary volcanism and faulting at the intersection of the Gulf of California and the Mexican Volcanic Belt: Geological Society of America Bulletin, v. 107, p. 612-626, doi:10.1130/0016-7606(1995)107<0612 :PQVAFA $>2.3 . \mathrm{CO} ; 2$.

Righter, K., Caffee, M., Rosas-Elguera, J., and Valencia, V., 2010, Channel incision in the Rio Atenguillo, Jalisco, Mexico, defined by $36 \mathrm{Cl}$ measurements of bedrock: Geomorphology, v. 120, p. 279-292, doi:10.1016/j .geomorph.2010.04.001.

Rosas-Elguera, J., Ferrari, L., Garduño-Monroy, V.H., and Urrutia-Fucugauchi, J., 1996, Continental boundaries of the Jalisco block and their influence in the Pliocene-Quaternary kinematics of western Mexico: Geology, v. 24, p. 921-924, doi:10.1130/0091-7613(1996)024<0921:CBOTJB >2 .3. $\mathrm{CO} ; 2$.

Rosas-Elguera, J., Ferrari, L., Martinez, M.L., and Urrutia-Fucugauchi, J., 1997, Stratigraphy and Tectonics of the Guadalajara Region and TripleJunction Area, Western Mexico: International Geology Review, v. 39, p. 125-140, doi:10.1080/00206819709465263.

Salinas-Prieto, J.C., Monod, O., and Faure, M., 2000, Ductile deformations of opposite vergence in the eastern part of the Guerrero terrane (SW Mexico): Journal of South American Earth Sciences, v. 13, p. 389-402, doi:10.1016/S0895-9811(00)00031-6.

Samson, S.D., and Alexander, E.C., Jr., 1987, Calibration of the interlaboratory ${ }^{40} \mathrm{Ar} /{ }^{39} \mathrm{Ar}$ dating standard, MMhb-1: Chemical Geology, v. 66, p. 27-34.

Schaaf, P., Morán-Zenteno, D., Hernández-Bernal, M., Solís-Pichardo, G., Tolson, G., and Köhler, H., 1995, Paleogene continental margin truncation in southwestern Mexico: geochronological evidence: Tectonics, v. 14, p. 1339-1350, doi:10.1029/95TC01928.

Selvans, M.M., Stock, J.M., DeMets, C., Sanchez, O., and Marquez-Azua, B., 2010, Constraints on Jalisco Block Motion and Tectonics of the Guadalajara Triple Junction from 1998-2001 Campaign GPS Data: Pure and Applied Geophysics, doi: 10.1007/s00024-010-0201-2.

Sun, S.S., and McDonough, W.F., 1989, Chemical and isotopic systematics of oceanic basalts; implications for mantle composition and processes, in Saunders, A.D. and Norry, M.J., eds., Magmatism in the ocean basins: Geological Society of London Special Publication 42, p. 313-345.

Tardy, M., Lapierre, H., Freydier, C., Coulon, C., Gill, J.-B., Mercier de Lepinay, B., Beck, C., and Martinez-Reyes, J., Talavera M., O., Ortiz, H., E., Stein, G., Bourdier, J.-L., and Yta, M., 1994, The Guerrero suspect terrane (western Mexico) and coeval arc terranes (the Great Antilles and the Western Cordillera of Colombia): a late Mesozoic intra-oceanic arc accreted to a cratonal America during the Cretaceous: Tectonophysics, v. 230, p. $49-73$.
Taylor, J.R., 1982, An introduction to error analysis: Mill Valley, California, University Science Books, $270 \mathrm{p}$.

Tortoledo, R.V., López, E.Z., and Suriano, E.C., 2011, Texto explicativo de la carta geologico-minera-geoquímica Tecolotlan, Estado de Jalisco, Servicio Geológico Mexicano, F13-D83, escala 1:50,000, 103 p.

Valencia, V.A., Ducea, M., Talavera-Mendoza, O., Gehrels, G., Ruiz, J., and Shoemaker, S., 2009, U-Pb geochronology of granitoids in the northwestern boundary of the Xolapa terrane: Revista Mexicana de Ciencias Geológicas, v. 26, no. 1, p. 189-200.

Valencia, V.A., Righter, K., Rosas-Elguera, J., López-Martínez, M., and Grove, M., 2013, The age and composition of the pre-Cenozoic basement of the Jalisco Block: implications for and relation to the Guerrero composite terrane: Contributions to Mineralogy and Petrology, v. 166, p. 801-824, doi:10.1007/s00410-013-0908-Z.

Vigouroux, N., Wallace, P.J., and Kent, A.J., 2008, Volatiles in high-K magmas from the western Trans-Mexican Volcanic Belt: evidence for fluid fluxing and extreme enrichment of the mantle wedge by subduction processes: Journal of Petrology, v. 49, no. 9, p. 1589-1618, doi:10.1093/petrology/egn039.

Wallace, P., and Carmichael, I.S.E., 1989, Minette lavas and associated leucitites from the western front of the Mexican Volcanic Belt: petrology, chemistry, and origin: Contributions to Mineralogy and Petrology, v. 103, p. 470-492, doi:10.1007/BF01041754.

Wallace, P., and Carmichael, I.S.E., 1992, Alkaline and calc-alkaline lavas near Los Volcanes, Jalisco, Mexico: Geochemical diversity and its significance in volcanic arcs: Contributions to Mineralogy and Petrology, v. 111, p. 423-439, doi:10.1007/BF00320899.

Winchester, J.A., and Floyd, P.A., 1977, Geochemical discrimination of different magma series and their differentiation products using immobile elements: Chemical Geology, v. 20, p. 325-343, doi:10.1016/0009-2541 (77)90057-2.

Webb, S.D., 1997, The Great American Faunal Interchange, in Coates, A.G., ed., Central America, A Natural and Cultural History: New Haven, Yale University Press, p. 97-122.

Wood, H.E., Chaney, R.W., Clark, J., Colbert, E.H., Jepsen, G.L., Reeside, J.B., Jr., and Stock, C., 1941, Nomenclature and correlation of the North American continental Neogene: Geological Society of America Bulletin, v. 52, p. 1-48, doi:10.1130/GSAB-52-1.

Zürcher, L., Ruiz, J., and Barton, M.D., 2001, Paragenesis, elemental distribution, and stable isotopes at the Peña Colorada iron skarn, Colima, Mexico: Economic Geology and the Bulletin of the Society of Economic Geologists, v. 96, p. 535-557, doi:10.2113/gsecongeo.96.3.535.

Manuscript Accepted by the Society 10 September 2016 
